\title{
Een leven lang leren in Nederland
}

Citation for published version (APA):

Borghans, L., Fouarge, D., \& de Grip, A. (2011). Een leven lang leren in Nederland. Researchcentrum voor Onderwijs en Arbeidsmarkt, Faculteit der Economische Wetenschappen. ROA Reports No. 5 https://doi.org/10.26481/umarep.2011005

Document status and date:

Published: 01/01/2011

DOI:

10.26481/umarep.2011005

Document Version:

Publisher's PDF, also known as Version of record

\section{Please check the document version of this publication:}

- A submitted manuscript is the version of the article upon submission and before peer-review. There can be important differences between the submitted version and the official published version of record.

People interested in the research are advised to contact the author for the final version of the publication, or visit the DOI to the publisher's website.

- The final author version and the galley proof are versions of the publication after peer review.

- The final published version features the final layout of the paper including the volume, issue and page numbers.

Link to publication

\footnotetext{
General rights rights.

- You may freely distribute the URL identifying the publication in the public portal. please follow below link for the End User Agreement:

www.umlib.nl/taverne-license

Take down policy

If you believe that this document breaches copyright please contact us at:

repository@maastrichtuniversity.nl

providing details and we will investigate your claim.
}

Copyright and moral rights for the publications made accessible in the public portal are retained by the authors and/or other copyright owners and it is a condition of accessing publications that users recognise and abide by the legal requirements associated with these

- Users may download and print one copy of any publication from the public portal for the purpose of private study or research.

- You may not further distribute the material or use it for any profit-making activity or commercial gain

If the publication is distributed under the terms of Article $25 \mathrm{fa}$ of the Dutch Copyright Act, indicated by the "Taverne" license above, 


\title{
Een leven lang leren in Nederland
}

\author{
Lex Borghans \\ Didier Fouarge \\ Andries de Grip
}

ROA-R-2011/5 


\section{Colofon}

(C) Researchcentrum voor Onderwijs en Arbeidsmarkt (ROA). Niets uit deze uitgave mag op enige manier worden verveelvoudigd zonder voorafgaande schriftelijke toestemming van de directeur van het ROA.

\section{Researchcentrum voor Onderwijs en Arbeidsmarkt}

School of Business and Economics

Maastricht University

\section{Vormgeving}

ROA secretariaat, Maastricht

\section{Verkoop}

Researchcentrum voor Onderwijs en Arbeidsmarkt email: secretary-roa-sbe@maastrichtuniversity.nl website: www.roa.nl

ISBN: 978-90-532I-500-5

mei $201 \mathrm{I}$ 


\section{Inhoud}

\section{Voorwoord}

Resumé

vii

1 Trends in het leren in Nederland 1

1.1 Ontwikkelingen in de cursusdeelname 1

$\begin{array}{ll}1.2 & \text { Ontwikkelingen in het informele leren }\end{array}$

1.3 Trends in de kennisontwikkeling 9

2 Werkinhoud $\quad 13$

2.1 Aspecten van huidige en alternatieve baan 13

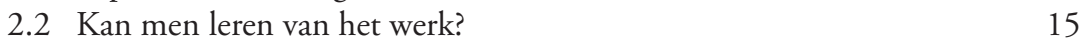

$\begin{array}{ll}2.3 \text { Veranderingen in de inhoud van het werk } & 17\end{array}$

2.4 Aspecten van werk en formeel en informeel leren 18

2.5 Aspecten van werk en kennisontwikkeling 21

3 Wie traint en wie leert? $\quad 25$

3.1 Trainingsdeelname en persoonlijkheid 25

$\begin{array}{ll}3.2 & \text { Informeel leren } \\ 3.3 & 29\end{array}$

3.3 Bereidheid tot het volgen van scholing en motivatie voor scholing 31

$\begin{array}{ll}3.4 & \text { Training door ouderen }\end{array}$

4 Ervaring, opbouw van menselijk kapitaal en mobiliteit 43

$\begin{array}{lll}4.1 & \text { Ervaring } & 43\end{array}$

4.2 Ervaring en kennisontwikkeling $\quad 45$

4.3 Arbeidsmarktgeschiedenis en leren op het werk 49

$\begin{array}{lll}4.4 & \text { Leren, employability en mobiliteit } & 51\end{array}$

5 Conclusie $\quad 59$

$\begin{array}{ll}\text { Literatuur } & 63\end{array}$

Bijlage A: ROA Levenslang Leren Enquête $\quad 65$

Bijlage B: Aspecten van werk

$\begin{array}{ll}\text { Bijlage C: Aanvullende tabellen bij hoofdstuk 3 } & 71\end{array}$ 



\section{Voorwoord}

Dit rapport brengt het formele en informele leren en de kennisontwikkeling in Nederland in beeld aan de hand van drie peilingen van de ROA Levenslang Leren Enquête (2004, 2007 en 2010). De continuering van deze monitor werd mogelijk gemaakt door middel van een subsidie van het Ministerie van Sociale Zaken en Werkgelegenheid. Wij danken Jana van Kuringen (Ministerie van Scoiale Zaken en Werkgelegenheid), Wendy Smits (Centraal Bureau voor de Statistiek) en Bas ter Weel (Centraal Planbureau) voor hun commentaar op een eerdere versie van dit rapport en hun input bij het opstellen van de vragenlijst die ten grondslag lag aan de 20 o peiling van de ROA Levenslang Leren Enquête. 



\section{Resumé}

In een kenniseconomie zoals de Nederlandse is er veel aandacht voor de mate waarin de beroepsbevolking verder leert. Dit leren kan betrekking hebben op het volgen van formele cursussen, maar ook op het leren op het werk zelf. Dit informele leren heeft vaak het karakter van leren door te doen, maar kan ook betrekking hebben op de dingen die men leert van collega's of leidinggevenden. Een intensiever leerproces kan leiden tot een grotere accumulatie van kennis en vaardigheden en daarmee iemands duurzame inzetbaarheid op de arbeidsmarkt vergroten.

Met dit rapport brengen wij het formele en informele leren en de kennisontwikkeling in Nederland in beeld aan de hand van drie peilingen van de ROA Levenslang Leren Enquête (2004, 2007 en 2010). Het monitorgedeelte van de enquête is door de jaren heen ongewijzigd gebleven. Dit maakt het mogelijk om trendmatige ontwikkelingen in het leren in Nederland in kaart te brengen en de factoren die dit leren bevorderen of belemmeren gedetailleerd te analyseren. We geven hier een opsomming van de belangrijkste bevindingen, met telkens een verwijzing naar het hoofdstuk waar verder op dit punt wordt ingegaan:

I. De deelname aan scholing door werkenden en niet-werkenden is in de periode 2004-20IO nagenoeg onveranderd gebleven. Er tekent zich door de jaren heen echter wel een verschuiving af in de deelname naar geslacht, opleidingsniveau en leeftijd (hoofdstuk I):

- Het deelnameverschil tussen vrouwen en mannen is verdwenen.

- De trainingsdeelname door hoogopgeleiden is tussen 2007 en 2010 toegenomen. Hierdoor groeit het verschil in trainingsparticipatie tussen de hoogst en de laagst opgeleiden.

- De trainingsdeelname van werkende ouderen (55-64 jaar) is tussen 2004 en 2010 gestegen.

2. De aan scholing bestede tijd is tussen 2007 en 2010 weer opgelopen tot gemiddeld 57 uur per cursus. Werknemers die een cursus hebben gevolgd geven aan dat ze gemiddeld genomen, naast de cursus, 23 uur nodig hebben gehad om dat wat zij geleerd hadden onder de knie te krijgen. Dat is minder dan in 2007 (hoofdstuk I).

3. Er is een harde kern van een op de vijf werkenden, die gedurende de loopbaan nog nooit een training of cursus heeft gevolgd. Het gaat hier vooral om laagopgeleiden en werkenden in de sectoren horeca, handel en cultuur. Het is niet duidelijk of hier sprake is van marktfalen. Het is immers mogelijk dat het in de functies waarin deze mensen werkzaam zijn niet noodzakelijk is om 
hun competenties door bijscholing op peil te houden. Vanuit het perspectief van een duurzame inzetbaarheid zijn dit wel duidelijke risicogroepen. Deze mensen zullen immers niet of nauwelijks in staat zijn om ander werk te kunnen krijgen als ze zich op een gegeven moment in hun loopbaan, bijvoorbeeld vanwege bepaalde belastende arbeidsomstandigheden, niet meer in hun huidige functie kunnen handhaven (hoofdstuk I en 5).

4. Het percentage van de werktijd dat werknemers besteden aan activiteiten waarvan zij kunnen leren neemt gestaag af. De afname tussen 2004 en 2007 heeft zich tussen 2007 en 2010 verder doorgezet. Deze daling doet zich uitsluitend voor bij laag- en middelbaar opgeleiden. Overigens is het nog steeds zo dat het overgrote deel van de tijd die werkenden besteden aan activiteiten waarvan ze leren betrekking heeft op informeel leren. Van de totale tijd waarin werkenden leren heeft slechts $7 \%$ betrekking op formeel leren. In 2004 was dit nog $8 \%$. In dat jaar werd er overigens niet alleen meer tijd besteed aan informeel leren, maar ook meer uren aan formeel leren (hoofdstuk I).

5. Formeel en informeel leren gaan overigens hand in hand. Werkenden die training volgen besteden gemiddeld genomen ongeveer 5,8 procentpunt meer tijd aan activiteiten waarvan zij dingen kunnen leren. Dit illustreert dat learning begets learning. Opmerkelijk is ook dat de respondenten aangeven dat een uur informeel leren gemiddeld evenveel oplevert als een uur cursus. Voor vrouwen lijkt informeel leren iets meer op te leveren dan voor mannen (hoofdstuk I).

6. Aspecten van het werk waarin iemand goed is zijn belangrijker voor het functioneren in de huidige baan dan om goed te kunnen functioneren in een mogelijke alternatieve baan. Werkenden zijn dus beter geëquipeerd voor hun huidige baan dan voor een andere baan waarin zij zouden kunnen gaan werken. Dit laat zien dat de duurzame inzetbaarheid van werkenden bij verlies aan werk kwetsbaar is. Het kunnen krijgen van een nieuwe baan maakt het in ieder geval voor veel werkenden noodzakelijk om nieuwe kennis en vaardigheden te leren. Het zou wenselijk zijn als een eventuele scholingsvoucher zich vooral op deze scholingsbehoefte richt (hoofdstuk 2 en 5 ).

7. Bij de kennisontwikkeling van werkenden is er een verschuiving van jong naar oud. Ouderen ontwikkelen zich steeds meer op het werk, jongeren daarentegen steeds minder (hoofdstuk I).

8. Vooral mensen met organiserende taken en met werk waarbij veel met anderen moet worden samengewerkt, leren veel op het werk, zowel formeel als informeel. Daarentegen leren mensen die routinewerk doen veel minder op hun werk. Wanneer iemand werk heeft waarvoor het werken met computers belangrijk is, worden er meer cursussen gevolgd. Daarenten is bij werk waarvoor intuïtie belangrijk is, het belang van informeel leren relatief groot (hoofdstuk 2).

9. Persoonlijkheid speelt een belangrijke rol bij de mate waarin mensen formeel en informeel leren. Zo blijkt het openstaan voor nieuwe ervaringen, zelfregulatie en de intrinsieke motivatie om te trainen positief gecorreleerd met de trainingsparticipatie. Ook hangen deze kenmerken negatief samen met de kans 
om nooit aan training deel te nemen. Tenslotte, blijkt dat mensen die meer risico willen nemen meer tijd spenderen aan taken waarvan zij kunnen leren. Persoonlijkheid speelt ook een belangrijke rol bij de scholingsparticipatie van werklozen en inactieven. Met name het openstaan voor nieuwe ervaringen en iemands intrinsieke motivatie bevorderen de trainingsdeelname. De vraag in hoeverre iemands persoonlijkheid verandert gedurende de levensloop en veranderd kan worden door beleidsinterventies is onderwerp van debat. Er zijn echter signalen dat vroege interventies effecten kunnen hebben op iemands persoonlijkheid. Dit suggereert dat het stimuleren van bepaalde attitudes in het initieel onderwijs positieve effecten kunnen hebben op het leven lang leren later in de loopbaan (hoofdstuk 3 en 5 ).

IO. Als werknemers een voucher voor het volgen van een cursus krijgen aangeboden zijn vooral meegaande mensen bereid deel te nemen als het aanbod van de werkgever komt, terwijl de meer zorgvuldige mensen juist minder geneigd zijn om op het aanbod in te gaan. Mensen die meer open staan voor nieuwe ervaringen en mensen met een hoge intrinsieke motivatie om te leren zijn eerder bereid om de voucher van de overheid te gebruiken. Ook weten ze vaker de specifieke cursus die ze zouden willen volgen (hoofdstuk 3).

II. De bereidheid om aan scholing deel te nemen is lager als een eigen financiële bijdrage wordt gevraagd en hoger als de training in de baas z'n tijd kan worden gevolgd (hoofdstuk 3).

I2. Onder werklozen en inactieven die een voucher van de overheid kunnen inzetten voor het volgen van scholing zijn vooral degenen met een sterke risicoattitude bereid de voucher te gebruiken. Dit illustreert dat het investeren in scholing voor niet-werkenden een risicovolle investering is, omdat het rendement, bij gebrek aan een baan, onzeker is. Vanuit dit oogpunt zou het zeer wenselijk zijn als werklozen die een scholing wordt aangeboden bij het behalen van een certificaat een werkgarantie krijgen. Daarentegen lijkt het weinig effectief om scholingsvouchers te verstrekken aan werkzoekenden die onzeker zijn of ze door het gebruik van de voucher wel werk kunnen vinden (hoofdstuk 3 en 5 ).

13. De scholingsbereidheid van werklozen is niet significant verschillend van die van werkenden. Werklozen zijn echter meer bereid om aan scholing deel te nemen dan de inactieven die zich niet aanbieden op de arbeidsmarkt. Daardoor volgen ze ook vaker scholing (hoofdstuk 3).

I4. Met het stijgen van de leeftijd ervaren werkenden vaker dat ze nu gemakkelijker problemen kunnen oplossen dan toen ze nog onervaren waren. Bij een kwart van de 55-plussers blijkt echter dat hun werkervaring hen niet in staat stelt om problemen die zich in hun werk voordoen gemakkelijker op te lossen dan toen ze nog jong waren (hoofdstuk 4).

I5. Bij veranderingen van werkzaamheden ervaart men vaak een tekort aan ervaring, maar deze veranderingen geven tegelijkertijd een impuls aan de kennisontwikkeling. Dit geldt ook voor oudere werkenden (hoofdstuk 4). 
I6. Oudere werkenden verwachten niet vaker dan jongeren dat ze de komende 5 jaar hun baan zullen kwijtraken. Daarentegen denken 45-plussers wel vaker dat ze een kleinere kans hebben om een andere baan op een vergelijkbaar niveau te kunnen krijgen als ze op zoek zouden gaan naar een baan op vergelijkbaar niveau. Vanuit beleidsperspectief pleit dit er voor om oudere werknemers vooral inzetbaar te houden in hun huidige baan, en te bewerkstelligen dat ze eerder in hun loopbaan door functieroulatie en/of verandering van het takenpakket binnen hun functie bredere kennis en vaardigheden opbouwen (hoofdstuk 4 en 5).

I7. Bedrijven zullen het leren op het werk kunnen versterken door bij de toebedeling van taken expliciet rekening te houden met de ervaring die iemand met het uitvoeren van bepaalde werkzaamheden kan opbouwen (hoofdstuk 2 en 5 ). 


\section{Trends in het leren in Nederland}

\subsection{Ontwikkelingen in de cursusdeelname}

De ROA Levenslang Leren Enquête is in het najaar van 2010 voor de derde keer gehouden. Eerdere metingen vonden in 2004 en 2007 plaats. ${ }^{.}$Omdat het monitorgedeelte van de enquête ongewijzigd is gebleven, kunnen de trendmatige ontwikkelingen in het leren in Nederland en de factoren die dit leren bevorderen of belemmeren in kaart worden gebracht. In deze paragraaf komen de ontwikkelingen in de cursusdeelname aan bod. In de daaropvolgende paragrafen zullen de trends in het informele leren en de kennisontwikkeling worden gepresenteerd.

$53 \%$ van de werkenden gaf in 2010 aan dat ze in de afgelopen twee jaar aan een of meerdere cursussen hadden deelgenomen. ${ }^{2}$ De deelname aan cursussen en trainingen in de afgelopen twee jaar is afgebeeld in figuur I.I voor de jaren 2004, 2007 en 2010. De figuur laat zien dat er tussen 2004 en 2007 sprake is van een lichte daling van de scholingsdeelname, maar dat er na 2007 weer een gedeeltelijk herstel optrad. De verschillen tussen de jaren zijn overigens niet statistisch significant. De figuur laat ook zien dat de scholingsdeelname onder niet-werkenden stabiel is en rond de $20 \%$ in de jaren 2004-20IO.

I. Over de bevindingen uit eerdere metingen wordt gerapporteerd in Borghans e.a. (2006, 2007, 2008a, 2009) en Fouarge e.a. (20I0). Zie bijlage I voor details over de enquêtes en de kernvariabelen daarin.

2. Met werkenden wordt in dit rapport bedoeld mensen die betaalde arbeid als belangrijkste bezigheid rapporteren. In verband met de representativiteit is de data gewogen naar geslacht, leeftijd en opleidingsniveau. 


\section{Figuur 1.1}

Formeel leren: ontwikkeling van de deelname aan cursussen en trainingen tussen 2004 en 2010*

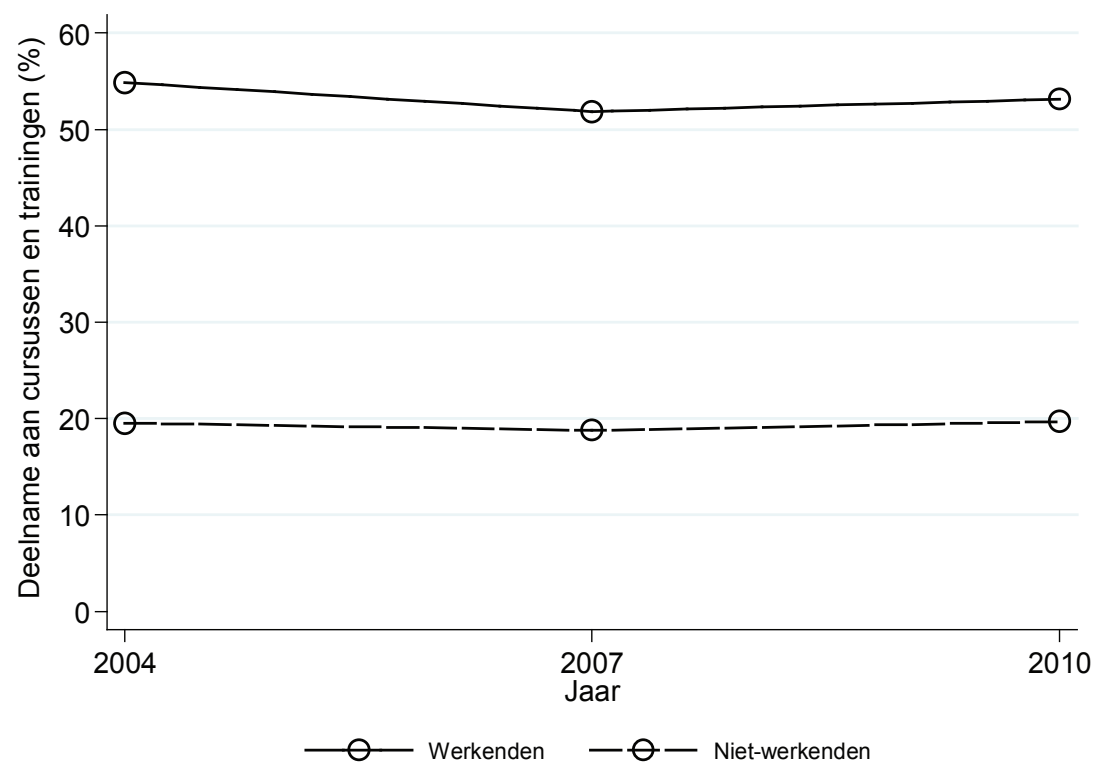

* De verschillen tussen werkenden en niet-werkenden zijn significant. De verschillen tussen de drie jaren zijn echter niet significant.

Een interessante vraag is in hoeverre mensen die de afgelopen twee jaar geen cursus of training hebben gevolgd dit in eerdere jaren wel hebben gedaan. Omdat het relatief vaak om jongeren (34 jaar of jonger) gaat die net van school afkomen en dus weinig mogelijkheden hebben gehad om cursussen te volgen beperken wij ons hierbij tot respondent tussen 35 en 64 jaar. Van degenen die in de afgelopen twee jaar geen cursus hebben gevolgd blijkt ongeveer $42 \%$ na het verlaten van het initieel onderwijs nooit een cursus of training te hebben gevolgd. Daarbij makt het niet uit of wij naar werkenden of niet-werkenden kijken. Dit betekent dat ongeveer een op de vijf werkenden tussen 35 en 64 jaar na het verlaten van het initieel onderwijs nog nooit aanvullende scholing heeft gevolgd. Het is opmerkelijk dat het percentage 35-plussers dat nog nooit aan een cursus of training heeft deelgenomen de afgelopen jaren licht is afgenomen van $29 \%$ in 2004 naar $23 \%$ in 2010 . Onder werkenden is dit percentage gedaald van $22 \%$ in 2004 naar $19 \%$ in 2010 . Maar er blijft kennelijk een harde kern van mensen die in hun arbeidsloopbaan nog nooit aan cursussen hebben deelgenomen. Het percentage dat nooit getraind heeft is vooral hoog onder laagopgeleiden, ${ }^{3}$ maar de verschillen naar leeftijd en geslacht zijn klein. Sectoren met het hoogste percentage

3. In het rapport wordt verwezen naar laagopgeleiden (basisonderwijs of vmbo), middelbaar opgeleiden (mbo of havo/vwo) en hoogopgeleiden (hbo of wo). 
werkenden dat nooit een training heeft gevolgd zijn de horeca (49\%), cultuur (37\%) en handel (39\%).

Het aantal cursussen en trainingen dat werkenden in twee jaar tijd volgen is licht gestegen van 2,4 in 2004 naar 2,6 in 2010. In 2010 gaat het dus om gemiddeld genomen I,3 cursussen per jaar in de afgelopen twee jaar. De tijd die werkenden die cursussen volgen gemiddeld aan een cursus besteden is tussen 2004 en 2007 sterk afgenomen van 68 naar 46 uur per cursus. De aan scholing bestede tijd is echter in 2010 weer opgelopen tot 57 uur per cursus. ${ }^{4}$ Dit betekent dat de intensiteit van de gevolgde cursussen tussen 2007 en 2010 weer is toegenomen met ongeveer Io uur per cursus. 5 Deze veranderingen zouden samen kunnen hangen met de conjunctuur. Laag-conjunctuur zou dan meer tijd voor cursussen betekenen. $56 \%$ van de cursustijd wordt besteed tijdens werktijd. In 2007 was dit iets meer: 59\%. De verschillen in de aan het volgen van cursussen bestede tijd zijn verassend klein tussen laag en middelbaar opgeleide werknemers: Laag opgeleiden besteden jaarlijks gemiddeld 53 uur aan een cursus en middelbaar opgeleiden 48 uur. Hoogopgeleiden besteden veel meer tijd aan cursussen: gemiddeld 67 uur per cursus.

$74 \%$ van de werkenden geeft aan dat ze wat ze geleerd hebben tijdens een cursus ook in de praktijk hebben kunnen toepassen. In de literatuur heet dit de transfer van de opgedane kennis en vaardigheden. Slechts $36 \%$ is van mening dat hun leidinggevende hen daartoe gestimuleerd heeft, terwijl $35 \%$ aangeeft dat hun collega's hen gestimuleerd hebben om wat ze geleerd hebben in praktijk te brengen. Vaak krijgt men echter de kennis en vaardigheden die men op een cursus heeft geleerd pas na enige tijd onder de knie. Werknemers die een cursus hebben gevolgd geven aan dat ze gemiddeld genomen, naast de cursus, 23 uur nodig hebben gehad om dat wat zij geleerd hadden onder de knie te krijgen. In 2007 was dit iets meer: 27 uur. $^{6}$ Terwijl er in 2007 minder tijd aan de cursussen zelf werd besteed, hadden werknemers in aanvulling op de cursus dus meer tijd nodig om het geleerde in de praktijk te brengen.

De in cursussen opgedane kennis komt niet alleen terecht bij degene die de cursus heeft gevolgd. Ook andere collega's kunnen daar indirect van profiteren. Er is in dat geval sprake van spillover-effecten. Ongeveer de helft van de werknemers die op cursus is geweest geeft aan de opgedane kennis te hebben overgedragen aan collega's.

In 2004 en 2007 liepen werkende vrouwen qua scholingsdeelname nog achter op de mannen. De cursusparticipatie van mannen is sinds 2004 echter afgenomen, terwijl die bij vrouwen tussen 2007 en 2010 is gestegen tot op hetzelfde niveau als dat van de mannen: $53 \%$. Verder blijkt dat de trainingsdeelname van werkende jongeren (I6-24

\footnotetext{
4. Wanneer wij ook mensen die geen cursussen volgen in deze berekening meenemen, dan blijkt dat er 30 uur aan een gemiddelde cursus of training besteed wordt. In 2004 was dit 37 uur.

5. Vooral mannen en oogopgeleiden besteden tussen 2007 en 2010 meer uren op cursus.

6. Vooral vrouwen en laagopgeleiden hebben tussen 2007 en 2010 minder tijd nodig om het geleerde onder de knie te krijgen.
} 
jaar) is afgenomen van $59 \%$ in 2004 naar $35 \%$ in $2010 .{ }^{7}$ Daarentegen blijkt de trainingsparticipatie van werkende ouderen ( $55-64$ jaar) te zijn toegenomen van $40 \%$ in 2004 en 2007 naar $48 \%$ in 2010. Figuur I.2 brengt deze verschuiving in de cursusparticipatie naar leeftijd over de jaren nader in beeld. ${ }^{8}$

\section{Figuur 1.2}

Formeel leren: ontwikkeling van deelname aan cursussen en trainingen door werkenden tussen 2004 en 2010, naar leeftijd*

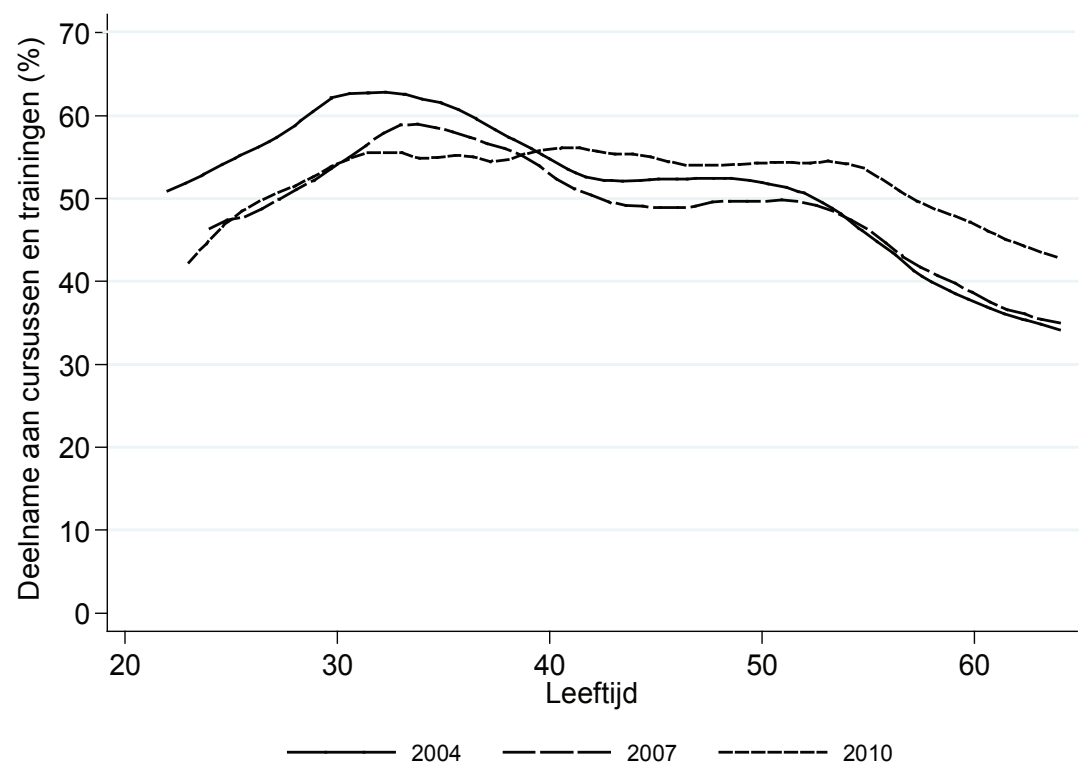

* De toename van de scholingsdeelname bij de ouderen tussen 2007 en 2010 is significant. De afname in formeel leren bij de jongeren tussen 2004 en 2007 is eveneens significant.

Figuur I.3 laat zien dat het in figuur I.I aangegeven lichte herstel in cursus- en trainingsparticipatie tussen 2007 en 2010 het gevolg is van de toegenomen trainingsparticipatie van de hoogst opgeleiden met een diploma op hbo- of wo-niveau. Bij de laagst opgeleiden is de scholingsparticipatie laag en de afgelopen jaren nauwelijks gestegen. Hierdoor groeit het verschil in trainingsparticipatie tussen de hoogst en de laagst opgeleiden (zie ook Fouarge e.a., 20IO).

7. Deze groep bevat echter weinig waarnemingen.

8. De daling in trainingsparticipatie onder jongeren doet zich zowel voor onder laag als hoog opgeleiden. De stijging in de trainingsparticipatie onder ouderen doet zich eveneens voor onder zowel laag als hoogopgeleiden. 


\section{Figuur 1.3}

Formeel leren: ontwikkeling van deelname aan cursussen en trainingen door werkenden tussen 2004 en 2010, naar opleidingsniveau*

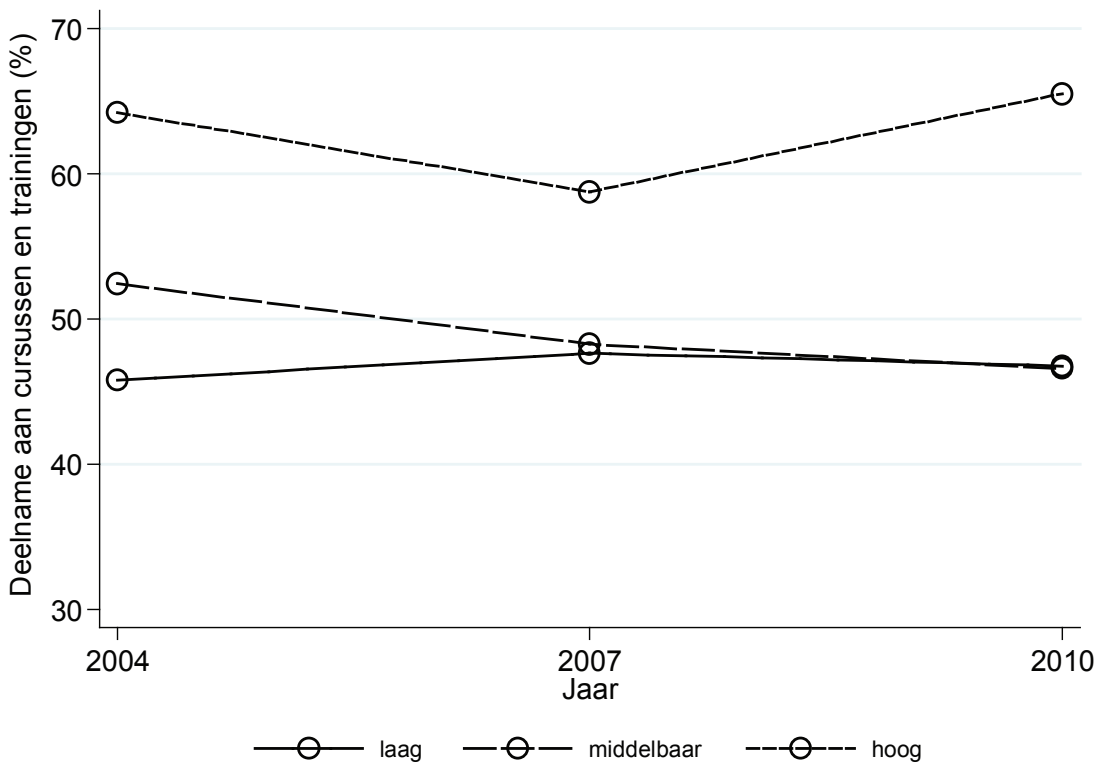

* Het verschil in formeel leren tussen hoogopgeleiden en middelbaar en laagopgeleiden is in alle jaren significant. De stijging in de scholingsparticipatie bij de hoogopgeleiden in 2010 is eveneens significant.

Van de hoogopgeleide werkenden geeft $42 \%$ aan dat ze de cursus hebben gevolgd omdat hun kennis en vaardigheden onvoldoende waren voor het werk dat zij doen (zie figuur I.4). Bij de lager opgeleiden is dit iets minder vaak de reden voor het volgen van een cursus. Bij de laagst opgeleiden geeft $47 \%$ aan dat het volgen van de cursus verplicht was. $\mathrm{Bij}$ de hoogopgeleide werkenden geeft ongeveer $30 \%$ van de werkenden aan dat het volgen van de cursus verplicht was. Bij ongeveer een kwart van de werkenden was het vergroten van de mogelijkheden voor een andere baan of het feit dat er een nieuwe manier van werken op het werk is geïntroduceerd de reden om aan de cursus deel te nemen. Daarbij zijn de verschillen naar opleidingsniveau klein. 


\section{Figuur 1.4}

Reden voor het volgen van cursus, werkenden naar opleidingsniveau, 2010

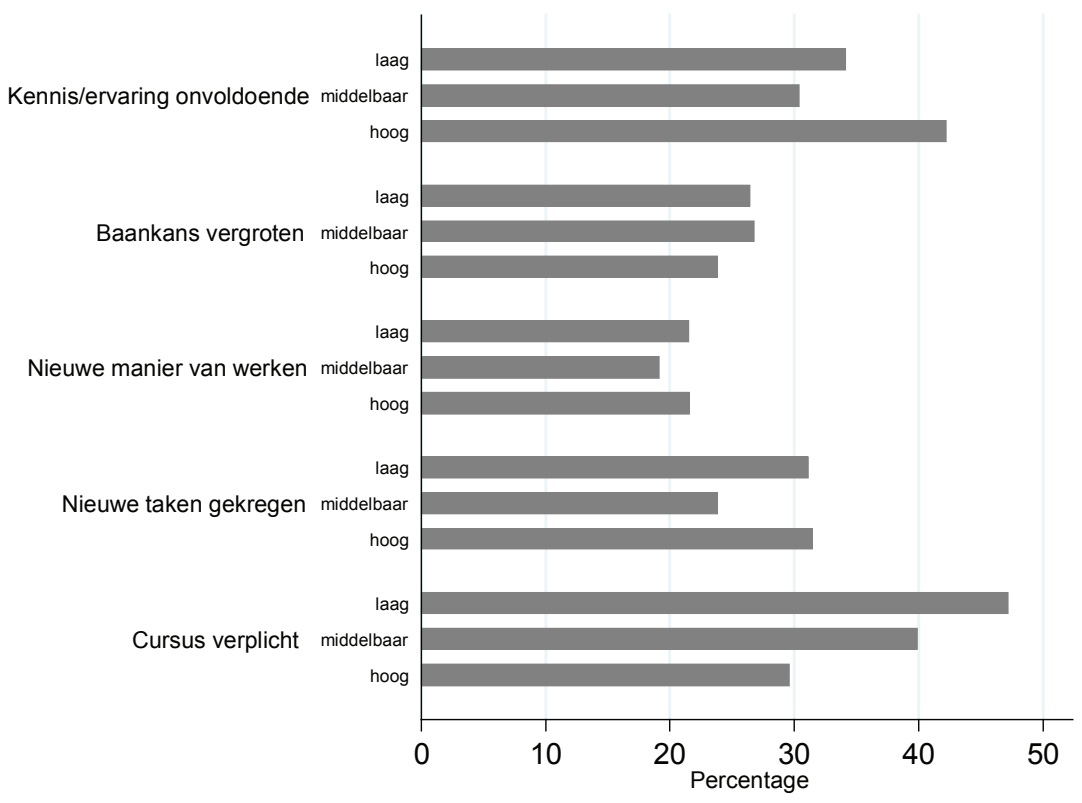

\subsection{Ontwikkelingen in het informele leren}

Informeel leren wordt gemeten aan de hand van de vraag hoeveel procent van de werktijd besteed wordt aan taken waarvan men kan leren. Dit percentage was tussen 2004 en 2007 afgenomen (Borghans e.a., 2009). Deze afname heeft zich tussen 2007 en 2010 verder doorgezet (figuur I.5). Terwijl werkenden in 2004 ongeveer $31 \%$ van hun werktijd besteden aan taken waarvan zij kunnen leren daalde dit naar $30 \%$ in 2007 en $28 \%$ in 2010 . De daling is niet groot, maar het gaat hier wel om een significante afname ten opzichte van 2004. Zoals blijkt uit figuur I.6 is deze afname vooral het gevolg van de afname in informeel leren in de leeftijdgroep van 40-55 jaar.

Vrouwen blijken procentueel gezien iets meer tijd te spenderen aan taken waarvan men kan leren (28\%) dan mannen (27\%). Echter, omdat vrouwen gemiddeld genomen een kortere werkweek hebben, besteden zij in absolute zin minder tijd aan taken waarvan zij kunnen leren dan mannen: 8,6 uur per week voor vrouwen tegenover II uur per week voor mannen. Verder blijken hoogopgeleiden meer tijd te besteden aan taken waarvan zij kunnen leren: gemiddeld genomen $32 \%$ van de werktijd. Voor laagopgeleiden en middelbaar opgeleiden is dit respectievelijk $26 \%$ en $25 \%$. Dit wijst er op dat hoogopgeleiden uitdagendere banen hebben. De tijd die hoogopgeleiden besteden aan taken waarvan zij kunnen leren is de afgelopen jaren ook min of meer stabiel 
gebleven. De eerder aangegeven daling doet zich alleen voor bij laag en middelbaar opgeleiden. In 2004 besteden beide groepen nog ongeveer $30 \%$ van hun werktijd aan taken waarvan zij kunnen leren.

\section{Figuur 1.5}

Informeel leren: ontwikkeling van het percentage van de werktijd besteed aan activiteiten waarvan men kan leren tussen 2004 en 2010, werkenden*

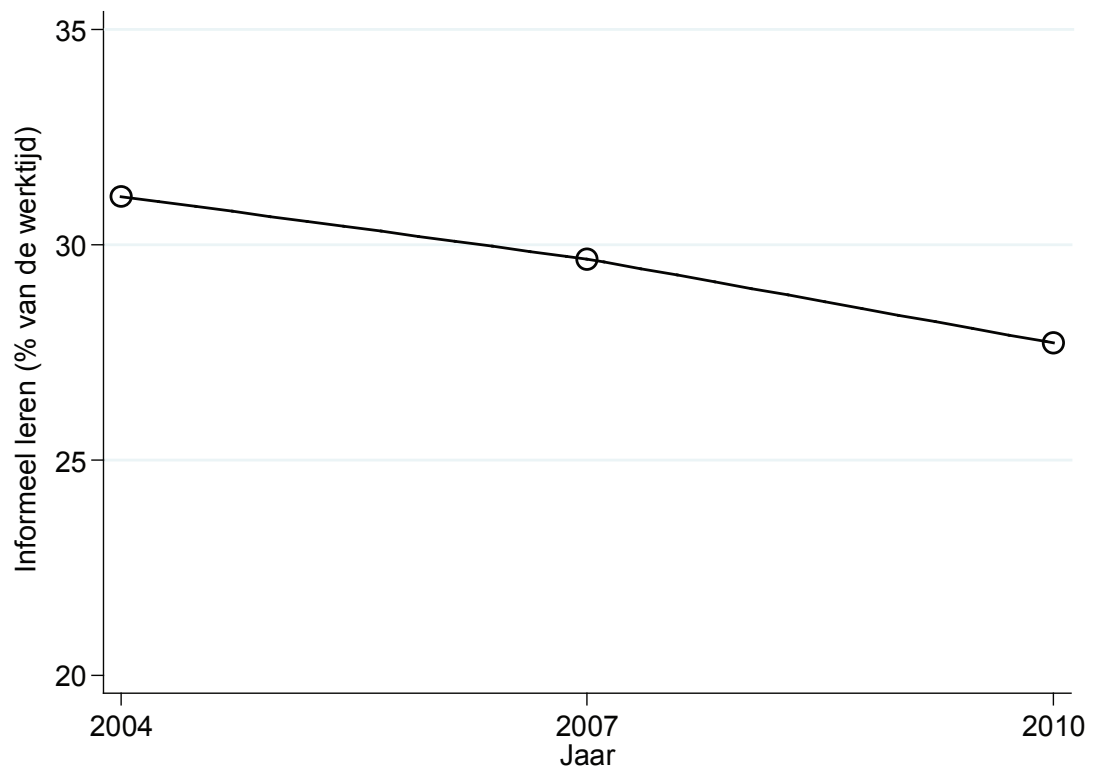

* De negatieve trend in informeel leren is significant.

Zoals gezegd geven werkenden gemiddeld aan dat ze $28 \%$ van hun werktijd besteden aan taken waarvan ze dingen kunnen leren. Dit betekent dat een gemiddelde werknemer per jaar gemiddeld 386 uur besteedt aan taken waarvan zij kunnen leren. ${ }^{9}$ Dat is zeer veel vergeleken met de tijd die er besteed wordt aan het volgen van cursussen: gemiddeld ongeveer 30 uur wanneer mensen die geen cursussen volgen ook mee worden geteld. Dit betekent dat voor een gemiddelde werknemer op jaar basis $7 \%$ van de totale tijd waarin men leert betrekking heeft op formeel leren. ${ }^{\circ}$ De rest, ongeveer $93 \%$ van de tijd waarin men leert, heeft betrekking op informeel leren. In 2004 had $8 \%$ van de totale tijd waarin men leert betrekking op formeel leren. In dat jaar werd niet alleen meer tijd besteed aan informeel leren, maar ook meer uren aan formeel leren. ${ }^{\text {II }}$

9. Berekend als $28 \%$ maal het gemiddeld aantal gewerkte uren per jaar (I,378 uren volgens de laatst beschikbare gegevens van de OESO).

Io. 30 uur formeel leren gedeeld door 386 (informeel) + 30 (formeel) uren leertijd. Het overeenkomstige percentage in lager, ongeveer $6 \%$, voor een voltijds werkende werknemers.

II. 37 uur formeel leren gedeeld door 422 (informeel) +37 (formeel) uren leertijd. 
Informeel en formeel leren gaan overigens hand in hand. De correlatie tussen de tijd die men besteedt aan taken waarvan men kan leren en de deelname aan cursussen is positief en significant in alle peilingen van de ROA Levenslang Leren Enquête. De correlatie is licht gedaald in de loop der jaren (van O,II in 2004 naar 0,06 in 20I0), maar de daling is niet significant. Kennelijk zijn formeel en informeel leren complementaire leeractiviteiten (zie ook Borghans e.a., 2009). Cursussen kunnen leren op het werk bevorderen. Werkenden die training volgen besteden gemiddeld genomen ongeveer 5,8 procentpunt meer tijd aan activiteiten waarvan zij kunnen leren. ${ }^{12}$ Bovendien is de samenhang tussen formeel en informeel leren niet significant verschillend tussen laag- en hoogopgeleiden.

\section{Figuur 1.6}

Informeel leren: ontwikkeling van het percentage van de werktijd besteed aan activiteiten waarvan men kan leren tussen 2004 en 2010, werkenden naar leeftijd*

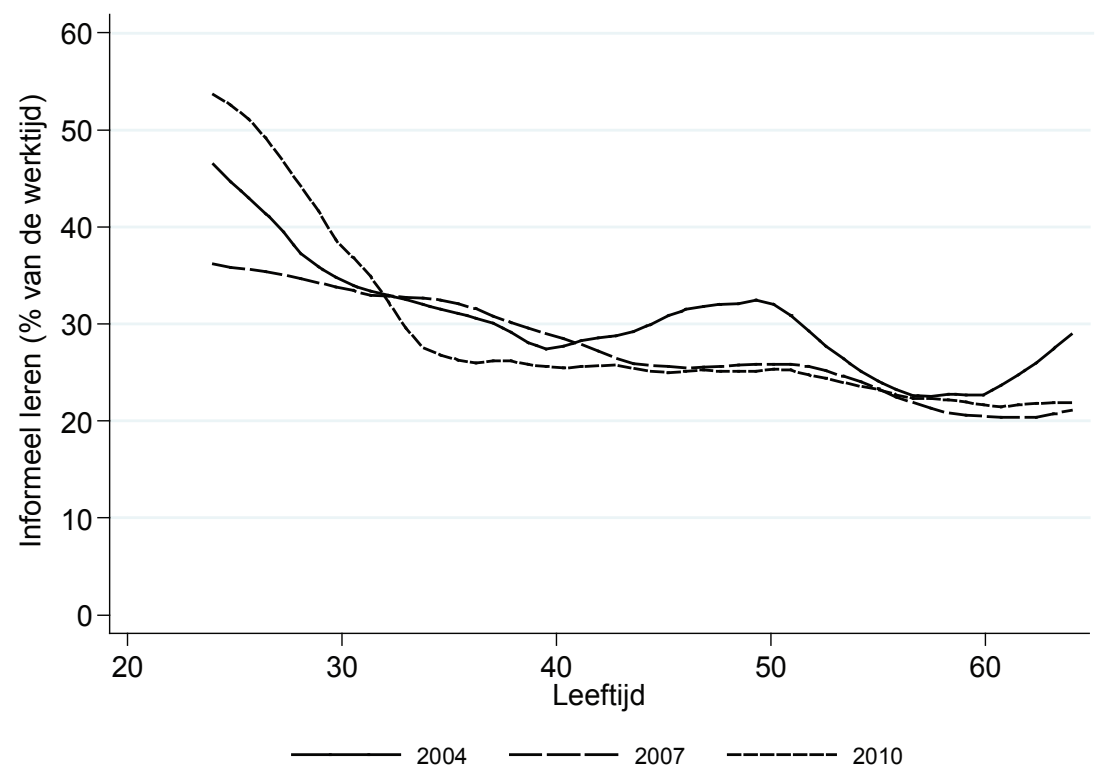

* De afname in informeel leren met het stijgen van de leeftijd is significant in alle jaren.

De grote hoeveelheid tijd die werknemers besteden aan taken waarvan zij kunnen leren roept de vraag op hoe groot het leerrendement van informeel leren is (zie paragraaf 2.5) en hoe het leerrendement van informeel leren zich verhoudt ten opzichte van dat van formele trainingen en cursussen. Om hier zicht op te krijgen is in de 20 Io ROA Levenslang Leren Enquête gevraagd om een vergelijking te maken tussen hoeveel respondenten denken te leren van een cursus en taken op het werk waarvan

I2. Wanneer wij controleren voor leeftijd, geslacht en opleidingsniveau is het verschil overigens kleiner: 3,5 procentpunten. 
men leert. ${ }^{13}$ Hieruit blijkt dat men gemiddeld genomen evenveel leert van een uur informeel leren als van een uur formele training. Dit zou betekenen dat er gemiddeld genomen geen verschil in het leerrendement van formeel en informeel leren. Omdat werknemers echter veel meer uren besteden aan het leren tijdens hun werk dan aan het volgen van cursussen of trainingen, kan geconcludeerd worden dat informele leeractiviteiten veruit de belangrijkste bron van nieuwe kennis en vaardigheden vormen.

Hoewel het leerrendement van een uur formeel en informeel leren gemiddeld genomen even hoog is, zijn er wel verschillen naar achtergrondkenmerken van de werkenden. Zo blijken vrouwen een significant hoger rendement van informeel leren te rapporteren dan mannen. In tegenstelling tot mannen, leren vrouwen meer van een uur informeel leren dan van een cursus van een uur. Mannen leren dus iets minder van een uur informeel leren dan van een cursus van een uur. Hoogopgeleiden rapporteren een significant lager rendement van informeel leren dan laagopgeleiden. Zij leren minder van een uur informeel leren dan van een cursus van een uur. Er zijn geen significante verschillen naar leeftijd of sector van activiteit in het rendement van formeel en informeel leren. Het is echter opmerkelijk dat werkenden die recent (in de afgelopen twee jaar) een cursus hebben gevolgd een hoger leerrendement van formeel leren rapporteren dan werknemers die langer geleden een cursus hebben gevolgd.

\subsection{Trends in de kennisontwikkeling}

Verwacht kan worden dat formeel en informeel leren leiden tot kennisontwikkeling. Kennisontwikkeling wordt gemeten met dezelfde subjectieve maatstaf als in de enquêtes uit 2004 en 2007. Daarbij vragen we de respondenten om zich de kennis en vaardigheden voor te stellen die nodig zijn om in hun werk optimaal te kunnen functioneren. Vervolgens wordt hen gevraagd hun eigen kennispeil op verschillende momenten in hun loopbaan in te schatten. Hierbij is het niveau dat nodig is om in hun werk optimaal te kunnen functioneren op Ioo gezet. ${ }^{\mathrm{I}}$ De kennisontwikkeling in de afgelopen twee jaar is vervolgens bepaald door het verschil te nemen tussen het huidige kennisniveau en dat van twee jaar geleden.

Het kennisniveau van niet-werkenden ligt ongeveer 17 procentpunten lager dan dat van werkenden. Het kennisniveau van de niet-werkenden is nagenoeg onveranderd gebleven in de periode 2004-2010. Daarentegen is het gepercipieerde kennisniveau van werkenden gedaald van 82 procent in 2004 en 2007 naar 77,5 procent in 2010. Het gaat hier om een statistische significante afname van ruim I,7 procentpunten op

I3. De vraag is alleen gesteld aan werkenden die in de afgelopen twee jaar of langer geleden een cursus hebben gevolgd. De vergelijking betrof 4 of 8 uren cursus en leren op het werk waarbij de waarden 4 en 8 zijn gerandomiseerd. Er zijn geen significante verschillen in de antwoorden naar de wijze van vraagstelling.

I4. Bij niet-werkenden is gevraagd om de baan die zij het liefst zouden willen doen als uitgangspunt te nemen. 
jaarbasis tussen 2007 en 2010 die niet verklaard kan worden op basis van veranderingen in de groep werkenden naar achtergrondkenmerken zoals leeftijd, geslacht, opleidingsniveau of het aantal gewerkte uren. Een mogelijke verklaring voor deze daling is dat het werk moeilijker is geworden. Met name onder invloed van de recent economische crisis kan het zo zijn dat werkenden zich realiseren dat er meer van hen verwacht wordt.

De kennisontwikkeling van werkenden - dat wil zeggen de mate waarin hun kennis en vaardigheden de afgelopen twee jaar zijn toe- of afgenomen - valt iets lager uit dan in 2004. Gemiddeld genomen was er in 2004 sprake van een toename van de kennis en vaardigheden in de voorafgaande twee jaar van 9 procentpunten. In 2010 werd er slechts een kennistoename van 8 procentpunten gemeten. Het verschil in kennisontwikkeling is echter niet significant. Uit regressie analyse - waarin gecontroleerd wordt voor leeftijd, geslacht en opleiding - is gebleken dat de kennisontwikkeling van werkenden significant en positief samenhangt met het formele en informele leren.

\section{Figuur 1.7}

Kennisontwikkeling van werkenden en niet-werkenden tussen twee jaar, naar leeftijd*

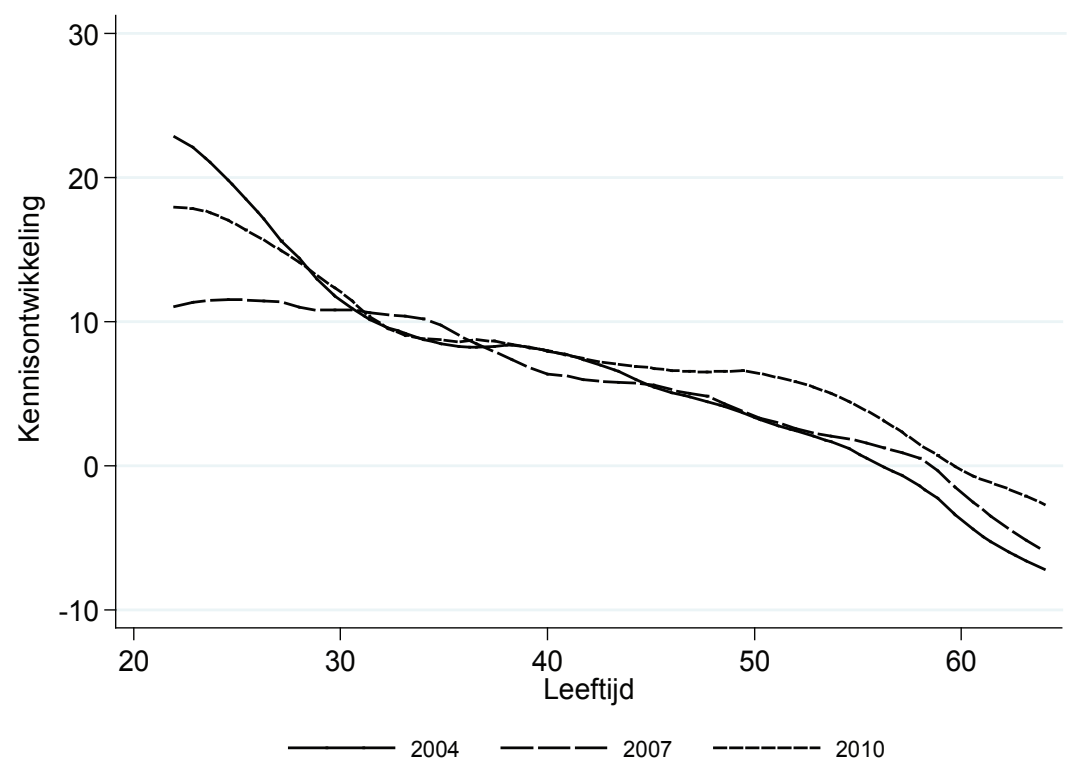

* De afname in kennisontwikkeling met het stijgen van de leeftijd is significant in alle jaren. De toename in kennisontwikkeling bij ouderen tussen 2010 en de voorgaande jaren is significant.

Figuur I.7 geeft een overzicht van de kennisontwikkeling van zowel werkenden als niet-werkenden in de voorafgaande twee jaar voor de periode 2004-20Io. Daaruit blijkt dat de kennisontwikkeling afneemt naarmate mensen ouder worden: de kennisontwikkeling is hoog op jonge leeftijd en wordt met het stijgen van de leeftijd steeds 
kleiner. Het laatste illustreert dat met het stijgen van leeftijd men te kampen krijgt met competentieveroudering, waardoor men minder goed kan functioneren op het werk (zie ook Fouarge en De Grip 20II).

Figuur I.7 laat zien dat er tussen 2004 en 2010 sprake is van een verschuiving van de kennisontwikkeling over de levensloop. De afname van de kennisontwikkeling met de leeftijd is vlakker geworden. Deze verschuiving blijkt statistisch significant te zijn. ${ }^{\text {Is }}$ Aan de ene kant is de kennisontwikkeling van jongeren afgenomen. Dit is consistent met de ontwikkelingen zoals die zijn gemeten in andere data bronnen zoals bijvoorbeeld de Adult Literacy and Life Skills Survey (Fouarge en De Grip 20II). Aan de andere kant is de kennisontwikkeling van ouderen juist verbeterd. Dit signaleert een toename in het menselijk kapitaal van ouderen, dat mogelijk gerelateerd is aan hun toegenomen deelname aan cursussen en trainingen en/of een anticipatie op een latere pensioneringsleeftijd: terwijl de kennisontwikkeling bij 50-64 jarigen met een baan in de twee jaren voorafgaand aan de meting in 20042 procentpunt bedroeg, was er in 2OIO sprake van een kennistoename van 4,5 procentpunt.

I5. Met behulp van een regressieanalyse is voor werkenden het leeftijdsprofiel voor de afzonderlijke enquêtejaren geschat. Daarbij is gecorrigeerd voor geslacht, opleidingsniveau en het aantal gewerkte uren. Het leeftijdsprofiel is bepaald aan de hand van de interactietermen tussen leeftijd en jaardummies. Het model laat zien dat er tussen 2004 en 2010 inderdaad sprake is geweest van een significant minder sterk wordende relatie tussen de kennisontwikkeling en iemands leeftijd. 



\section{Werkinhoud}

\subsection{Aspecten van huidige en alternatieve baan}

Omdat mensen veel leren van de taken die ze uitoefenen op het werk gaan we in dit hoofdstuk in op de inhoud van het werk. In de ROA Levenslang Leren Enquête 2007 en 2010 is aan respondenten gevraagd welke twee aspecten ${ }^{16}$ het meest belangrijk zijn om hun werk succesvol uit te kunnen voeren, terwijl aan niet-werkenden is gevraagd om twee aspecten te noemen die belangrijk zijn voor de baan die in uw ogen voor hen geschikt en haalbaar zou zijn. Het is van belang om te benadrukken dat het hier om algemene aspecten van het werk gaat, waarvoor bepaalde generieke vaardigheden vereist zijn, die ook in andere banen ingezet kunnen worden.

Uit de antwoorden van de respondenten in 20 Io blijkt dat het "omgaan met mensen" het belangrijkste aspect is gevolgd door "vakspecifieke kennis" en "duidelijk communiceren". Deze volgorde is precies hetzelfde als in 2007. Er zijn echter wel verschillen naar opleidingsniveau. Voor elk opleidingsniveau zijn het "omgaan met mensen" en "vakspecifieke kennis" weliswaar de meest belangrijke aspecten, maar "vakspecifieke kennis" staat op de eerste plaats bij de hoogopgeleiden (hbo/wo), maar op de tweede plaats bij laag- (vbo) en middelbaar opgeleiden (mbo/havo/vwo). Duidelijk communiceren is het derde belangrijkste aspect voor hoogopgeleiden, maar bij laagen middelbaar opgeleiden is "nauwkeurigheid" het derde meest belangrijke aspect van hun werk.

Hoe interessant vinden werkenden de verschillende aspecten van het werk en hoe goed is men erin? Om deze vraag te kunnen beantwoorden is aan werkenden gevraagd hoe interessant men de twee belangrijkste aspecten van hun werk vindt. Daarbij is gebruik gemaakt van een schaal van I (helemaal niet interessant) tot 5 (heel erg interessant). Daarnaast is gevraagd hoe goed men is in deze aspecten. Daarbij is gebruik gemaakt van een schaal van I (helemaal niet goed) tot 5 (heel erg goed). De antwoorden op beide vragen worden in figuur 3.I afgebeeld. Er is sprake van een positieve en significant relatie tussen wat men interessant vindt aan het werk en de mate waarin men zichzelf daarin goed vindt. In de figuur zijn ook twee lijnen opgenomen die het

I6. Te kiezen uit een lijst van 26 items. De volledige lijst is opgenomen in tabel B.I in de bijlage. 
gemiddelde aangeven van hoe goed men in de verschillende aspecten van het werk is en hoe interessant men het betreffende aspect vindt.

De figuur laat zien dat er een aantal aspecten is die werkenden interessant vinden, terwijl ze er ook relatief goed in zijn (vak rechtsboven in de figuur). Het gaat hier om analytisch denken, vakspecifieke en technische kennis, nauwkeurigheid, informatie verzamelen en verwerken, omgaan met mensen, organiseren en doorzettingsvermogen. Ook zijn er vaardigheden waar men relatief minder goed in is en die men ook minder interessant vindt. Dit geldt met name voor commercieel inzicht en het werken met computers, maar ook voor vaardigheden op het gebied van talen en schijven (buitenlandse talen, schrijven, presenteren) en time management.

\section{Figuur 2.1}

Aspecten van het werk: hoe interessant vindt men die en hoe goed is men er in? (werkenden, 2010)

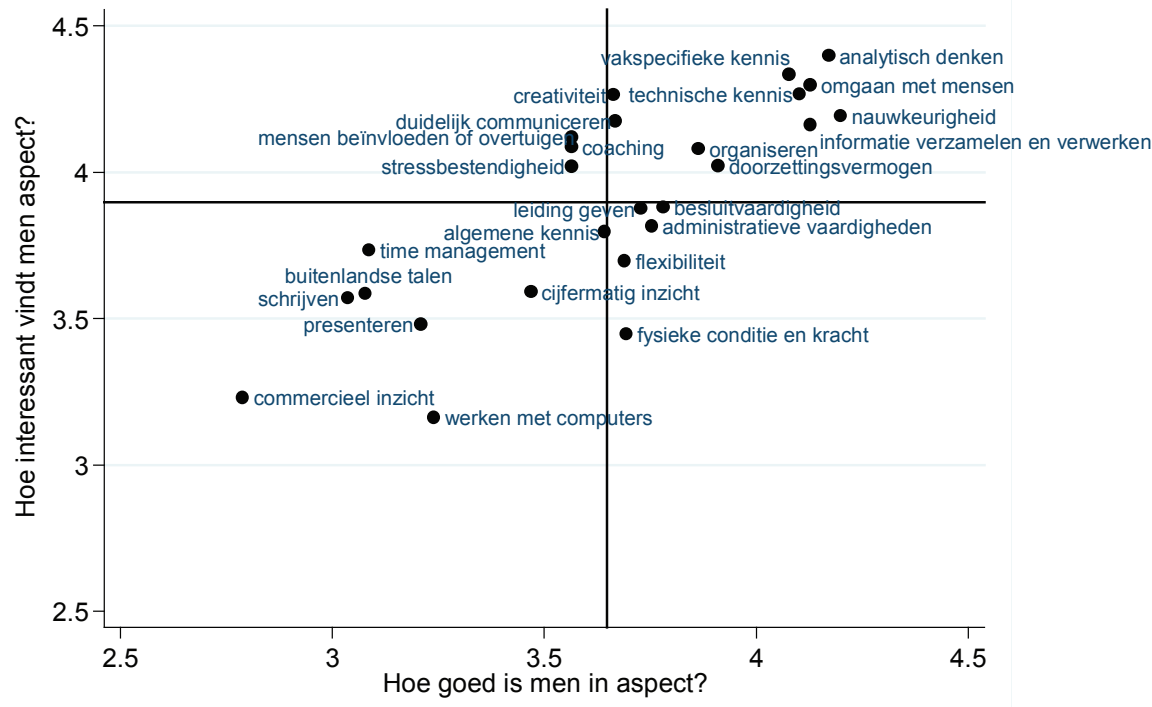

Aan werkenden is gevraagd een baan te noemen die een geschikt en haalbaar alternatief zou zijn voor hun huidige baan. Vervolgens is hen gevraagd om aan te geven wat het belangrijkst werkaspect is (uit een lijst van 26 items) voor deze alternatieve baan waarvoor zij nog weinig kennis of vaardigheden hebben. ${ }^{17}$ Voor dit werkaspect en de twee belangrijkste werkaspecten van de huidige baan (zoals beschreven in figuur 2.I) is gevraagd hoe belangrijk het betreffende aspect is (op een schaal van I "helemaal niet van belang" tot 5 "van zeer groot belang") in de huidige en de alternatieve baan. De antwoorden worden in figuur 3.2 vergeleken. In de figuur is een 45 -graden lijn opgenomen om aan te geven welke vaardigheden in de alternatieve baan belangrijker (boven de lijn) of minder belangrijk (onder de lijn) zijn dan in de huidige baan.

I7. De top drie bestaat uit omgaan met mensen, vakspecifieke kennis en mensen beïnvloeden of overtuigen. 
Uit de figuur blijkt dat een aantal aspecten belangrijker is voor de alternatieve baan dan voor de huidige baan. Het gaat met name om buitenlandse talen, schrijven, presenteren, cijfermatig inzicht, mensen beïnvloeden of overtuigen, leiding geven, time management en besluitvaardigheid. Deze aspecten doet vermoeden dat de respondent bij de alternatieve baan een hogere functie in gedachte heeft. Opmerkelijk is dat de correlatie tussen de aspecten waarin iemand goed is en het belang daarvan voor het goed functioneren in de alternatieven baan kleiner is dan de correlatie van de aspecten waarin iemand goed is en het belang daarvan voor het functioneren in de huidige baan. Dit suggereert dat werknemers alleen in deze alternatieve baan zullen kunnen functioneren wanneer zij aanvullende scholing volgen.

\section{Figuur 2.2}

Belang van verschillende aspecten van het werk in huidige en alternatieve baan (werkenden, 2010)

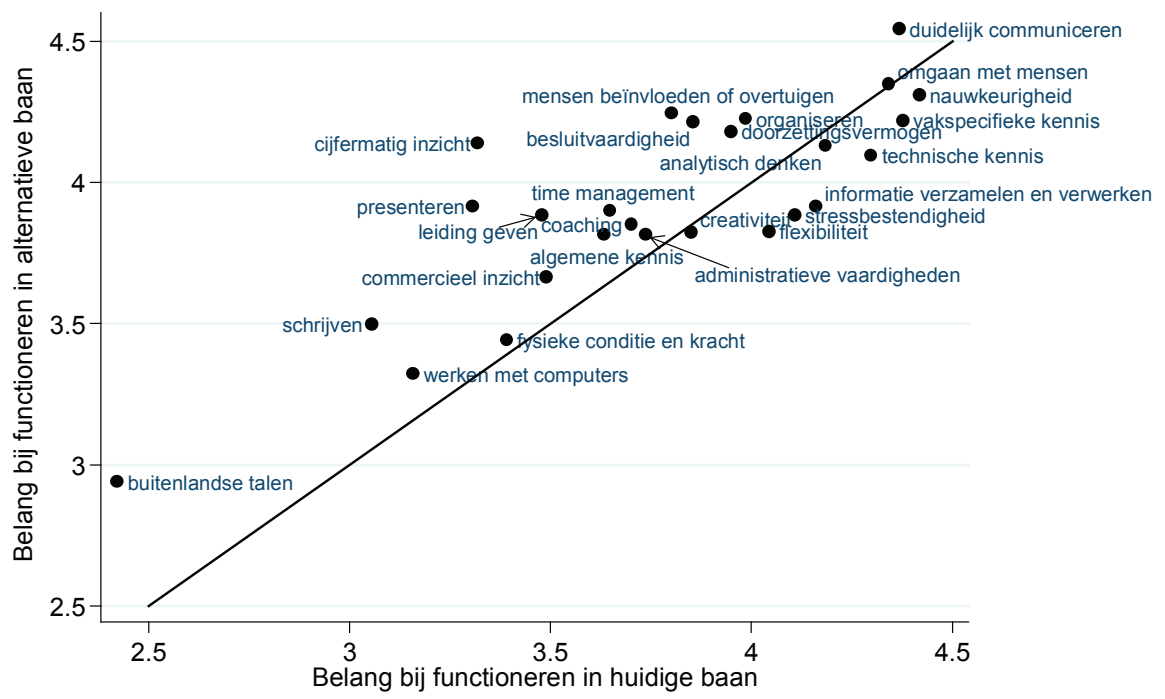

\subsection{Kan men leren van het werk?}

De taken die mensen hebben op hun werk lopen vaak zeer uiteen. Er wordt tijd besteed aan routinewerkzaamheden, nieuwe werkzaamheden die men nog niet eerder heeft uitgevoerd, vergaderen of samenwerken. Gemiddeld genomen wordt ongeveer de helft van de werktijd besteed aan routinewerkzaamheden (tabel 2.I). Zoals verwacht mag worden, ligt dit veel hoger bij de laagopgeleiden (60\%) dan bij de hoogopgeleiden (40\%). Hoogopgeleiden besteden meer tijd aan werkzaamheden waarbij zij voor uitdagingen staan die zij moeten oplossen (20\% van de werktijd tegenover I2\% bij de laagopgeleiden), maar ook aan vergaderen en overleggen (I2\% van de werktijd tegenover $5 \%$ bij laagopgeleiden). Er is geen verschil in de werktijd die hoger- en 
lageropgeleiden besteden aan samenwerken. Ook de verschillen naar leeftijd en de verschillen tussen mannen en vrouwen zijn klein. Wel neemt het percentage van de werktijd dat besteed wordt aan samenwerken met mensen waarvan men veel kan leren (het informele leren van collega's) af naarmate mensen ouder worden. Dit wijst op het belang van ervaring in het werk en de kennisoverdracht op de werkvloer. In hoofdstuk 4 komen wij daar op terug.

Tabel 2.1

Percentage van de werktijd dat de afgelopen week is besteed aan verschillende soorten werkzaamheden, werkenden naar opleidingsniveau, 2010

\begin{tabular}{|lcccc|} 
& Laag & Middelbaar & Hoog & Totaal \\
& $\%$ & $\%$ & $\%$ & $\%$ \\
\hline Alledaagse routinewerkzaamheden & 60 & 53 & 40 & 50 \\
\hline Werkzaamheden waarbij ik voor uitdagingen sta die ik moet oplossen & 12 & 15 & 20 & 16 \\
\hline Werkzaamheden die ik nog niet eerder heb gedaan & 4 & 5 & 5 & 5 \\
\hline Vergaderen/overleg & 5 & 7 & 12 & 8 \\
\hline Samenwerken met mensen van wie ik veel kan leren & 8 & 8 & 9 & 8 \\
\hline Samenwerken met mensen die veel van mij kunnen leren & 11 & 12 & 14 & 13
\end{tabular}

Aan de respondenten is ook gevraagd om op basis van een vijf-puntsschaal de aard van hun werk te beschrijven met betrekking tot een viertal punten: I) of het werk creatief is of eerder routinematig, 2) gemakkelijk of moeilijk, 3) of het werk eerder draait om kennis of intuïtie, en 4) of het werk vooral alleen wordt verricht of veel samenwerking vereist.

Figuur 2.3 illustreert de verschillen in de aard van het werk naar opleidingsniveau. Het werk van hoogopgeleiden is eerder creatief en moeilijk te noemen, terwijl het werk van laag en middelbaar opgeleiden eerder routinematig is en gekenmerkt wordt door een gemiddelde moeilijkheidsgraad. Hoewel het werk in het algemeen eerder op kennis dan op intuïtie berust, blijken er op dit punt geen significante verschillen te zijn tussen het werk van laag- en dat van hoogopgeleiden. De mate van samenwerking verschilt ook niet significant naar opleidingsniveau.

De verschillen naar leeftijd zijn klein behalve als het gaat om het samenwerken versus het alleen werken. Het werk van jongeren (I6-34 jaar) vereist meer samenwerking terwijl ouderen (55-64 jaar) hun werk meer alleen doen. Wel zijn er interessante verschillen tussen de banen van mannen en vrouwen. Vrouwen geven significant vaker aan dat intuïtie belangrijk is voor hun baan, terwijl mannen significant vaker aangeven dat hun baan moeilijk is. 
Figuur 2.3

Aard van het werk, naar opleidingsachtergrond, werkenden, 2010

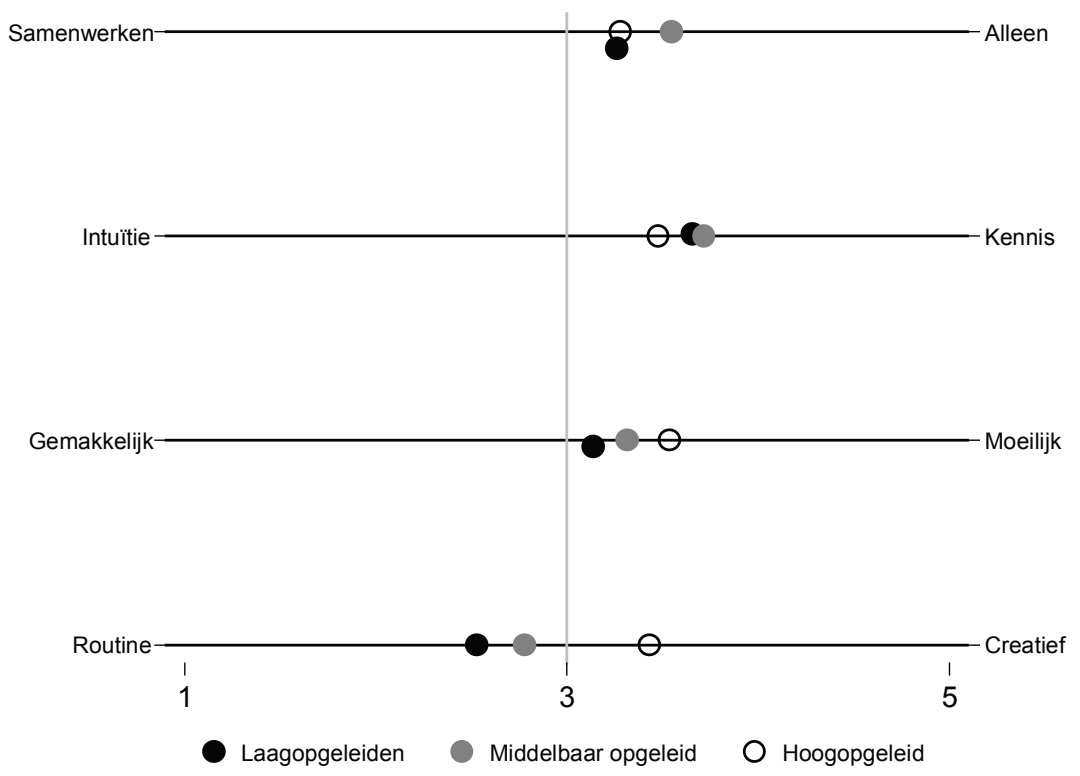

\subsection{Veranderingen in de inhoud van het werk}

Bij een kwart van de werkenden doen zich grote tot zeer grote veranderingen voor in de inhoud van het werk, terwijl er bij $37 \%$ van de werkenden geen of slechts kleine veranderingen in het werk voordoen (tabel 2.2). Vooral bij hoogopgeleiden is er vaak sprake van veranderingen in de inhoud van het werk. Zo geeft 3I\% van de hoogopgeleiden aan dat er sprake is van grote tot zeer grote veranderingen in hun werk, tegenover slechts I6\% van de laagopgeleiden. Grote en zeer grote veranderingen in het werk worden het vaakst door werknemers in de financiële en zakelijke dienstverlening, openbaar bestuur, onderwijs en zorg en welzijn gerapporteerd (ongeveer 30\%). 
Tabel 2.2

Mate waarin zich op het werk ontwikkelingen voordoen die de inhoud van het werk veranderen, werkenden, 2010

\begin{tabular}{lccc|} 
& $\begin{array}{c}\text { (Zeer) grote } \\
\text { ontwikkelingen }\end{array}$ & $\begin{array}{c}\text { Gemiddelde } \\
\text { ontwikkelingen }\end{array}$ & $\begin{array}{c}\text { Kleine of geen } \\
\text { ontwikkelingen }\end{array}$ \\
\hline Laagopgeleid & 16 & $\%$ & $\%$ \\
\hline Middelbaar opgeleid & 25 & 36 & 48 \\
\hline Hoogopgeleid & 31 & 33 & 41 \\
\hline totaal & 25 & 44 & 25 \\
\hline
\end{tabular}

Ongeveer een kwart van de werkenden kan de veranderingen in het werk redelijk tot slecht bijbenen. Laagopgeleiden hebben significant meer moeite met het bijbenen van veranderingen in de inhoud van het werk dan middelbaar en hoogopgeleiden. Er zijn daarentegen geen significante verschillen tussen mannen en vrouwen. Ook tussen jongeren en ouderen zijn er geen verschillen in de mate waarin men moeite heeft met het bijbenen van veranderingen in het werk. Dit geldt ook wanneer men kleine veranderingen in het werk buiten beschouwing laat. Dit suggereert dat ook oudere werknemers prima in staat zijn om veranderingen in de inhoud van het werk bij te benen. Duidelijk blijkt ook het belang van bijscholing. Werknemers die in de afgelopen twee jaar cursussen hebben gevolgd hebben minder moeite met het bijbenen van de veranderingen in hun werk. Ten slotte is het opmerkelijk dat de mensen die werkzaam zijn in de handel en horeca of de sector zorg en welzijn meer moeite hebben om grote veranderingen in hun werk bij te benen dan werknemers uit andere sectoren. Dit geldt ook waanneer rekening wordt gehouden met de gevolgde bijscholing.

\subsection{Aspecten van werk en formeel en informeel leren}

In tabel 2.3 relateren wij de scholingsdeelname van werkenden aan verschillende kenmerken van de baan en de werkzaamheden in die baan. Uit de tabel blijkt dat sommige kenmerken van het werk positief samenhangen met het al dan niet deelnemen aan scholing. Dit geldt bijvoorbeeld voor het uitvoeren van organiserende taken (model 2) en de tijd die men besteedt aan vergaderen/overleg (model 4). In beide gevallen verklaren deze kenmerken van het werk de lagere scholingsparticipatie van ouderen. Routinewerk en werk dat vooral berust op intuïtie (model 3) gaat gepaard, zoals men zou kunnen verwachten, met een lagere scholingsparticipatie. Van de meest belangrijkste aspecten van het werk (model 5) blijkt alleen 'werken met computers' significant gecorreleerd te zijn met de scholingsdeelname. De verschillende taken die mensen op hun werk moeten uitvoeren blijken voor een belangrijk deel de hogere scholingsdeelname van hoger opgeleiden te kunnen verklaren (model 3). 
Tabel 2.3

Relatie tussen de aard van de werkzaamheden en de kans op participatie aan cursus of training in de afgelopen twee jaar, 2010 (coëfficiënten uit probit model)
(1)
(2)
(3)
(4)
(5)

\section{Verklarende variabelen}

Mate waarin werk berust op uitvoeren dan wel organiseren van taken

uitvoerend werk

0,014

organiserende taken

$0,188^{* * *}$

Kenmerken van het werk (zoals besproken in figuur 3.3)

$\begin{array}{lc}\text { routine werk } & -0,186^{* * *} \\ \text { moeilijk werk } & 0,044 \\ \text { intuïtie } & -0,081^{*} \\ \text { samenwerken } & 0,063^{*}\end{array}$

Percentage van de werktijd besteed aan:

\begin{tabular}{ll}
\hline (alledaagse) routine werkzaamheden & $-0,005$ \\
\hline werkzaamheden waarbij ik voor uitdagingen sta die ik moet oplossen & 0,004 \\
\hline werkzaamheden die ik nog niet eerder heb gedaan & 0,001 \\
\hline vergaderen/overleg & $0,059^{* * *}$ \\
\hline samenwerken met mensen van wie ik veel kan leren & 0,002 \\
\hline samenwerken met mensen die veel van mij kunnen & 0,005
\end{tabular}

Belangrijkst aspect van het werk (ref: omgaan met mensen)

werken met computers

$0,974^{* *}$

alle overige aspecten

n.s.

Controle variabelen ${ }^{1)}$

\begin{tabular}{|lllllll}
$\begin{array}{l}\text { Vrouw } \\
\text { Leeftijd (ref: } 35-44 \text { jaar) }\end{array}$ & 0,020 & 0,073 & 0,084 & 0,098 & 0,114 \\
\hline 16-24 jaar & & & & & \\
\hline 25-34 jaar & $-0,299$ & $-0,322$ & $-0,459$ & $-0,248$ & $-0,281$ \\
\hline 45-54 jaar & $-0,178$ & $-0,136$ & $-0,113$ & $-0,150$ & $-0,169$ \\
\hline 55-64 jaar & $-0,056$ & $-0,032$ & $-0,048$ & $-0,058$ & $-0,059$ \\
\hline Opleiding (ref: mbo) & $-0,248^{* *}$ & $-0,183$ & $-0,190$ & $-0,195$ & $-0,250^{* *}$ \\
\hline \multicolumn{1}{|c|}{ bo/vmbo } & & & & & \\
\hline havo/vwo & $-0,103$ & $-0,089$ & $-0,055$ & $-0,032$ & $-0,116$ \\
\hline hbo & $-0,125$ & $-0,046$ & $-0,060$ & $-0,073$ & $-0,178$ \\
\hline wo & $0,312^{* *}$ & $0,288^{* *}$ & 0,207 & $0,231^{*}$ & $0,260^{* *}$ \\
\hline Constante term & $0,278^{*}$ & $0,357^{* *}$ & 0,233 & 0,222 & 0,236 \\
\hline Pseudo-R-kwadraat & 0,258 & 0,242 & $0,731^{* *}$ & 0,100 & 0,239 \\
\hline N & 0,042 & 0,058 & 0,069 & 0,077 & 0,058 \\
\hline
\end{tabular}

${ }^{*} \mathrm{p}<0.10^{* *} \mathrm{p}<0.05^{* * *} \mathrm{p}<0.01$

n.s. = niet significant

1) Overige controles: sector van activiteit, burgerlijke staat, aantal kinderen 
HOOFDSTUK 2

Tabel 2.4

Relatie tussen de aard van de werkzaamheden en de mate waarin men informeel leert, 2010 (coëfficiënten uit OLS model)
(1)
(2)
(3)
(4)
(5)

\section{Verklarende variabelen}

Mate waarin werk berust op uitvoeren dan wel organiseren van taken

uitvoerend werk

organiserende taken

$4,131^{* * *}$

Kenmerken van het werk (zoals besproken in figuur 3.3)

\begin{tabular}{|lc|}
\hline routine werk & $-5,205^{* * *}$ \\
\hline moeilijk werk & $1,874^{*}$ \\
\hline intuïtie & $1,571^{*}$ \\
\hline samenwerken & $2,157^{* * *}$ \\
\hline
\end{tabular}

Percentage van de werktijd besteed aan:

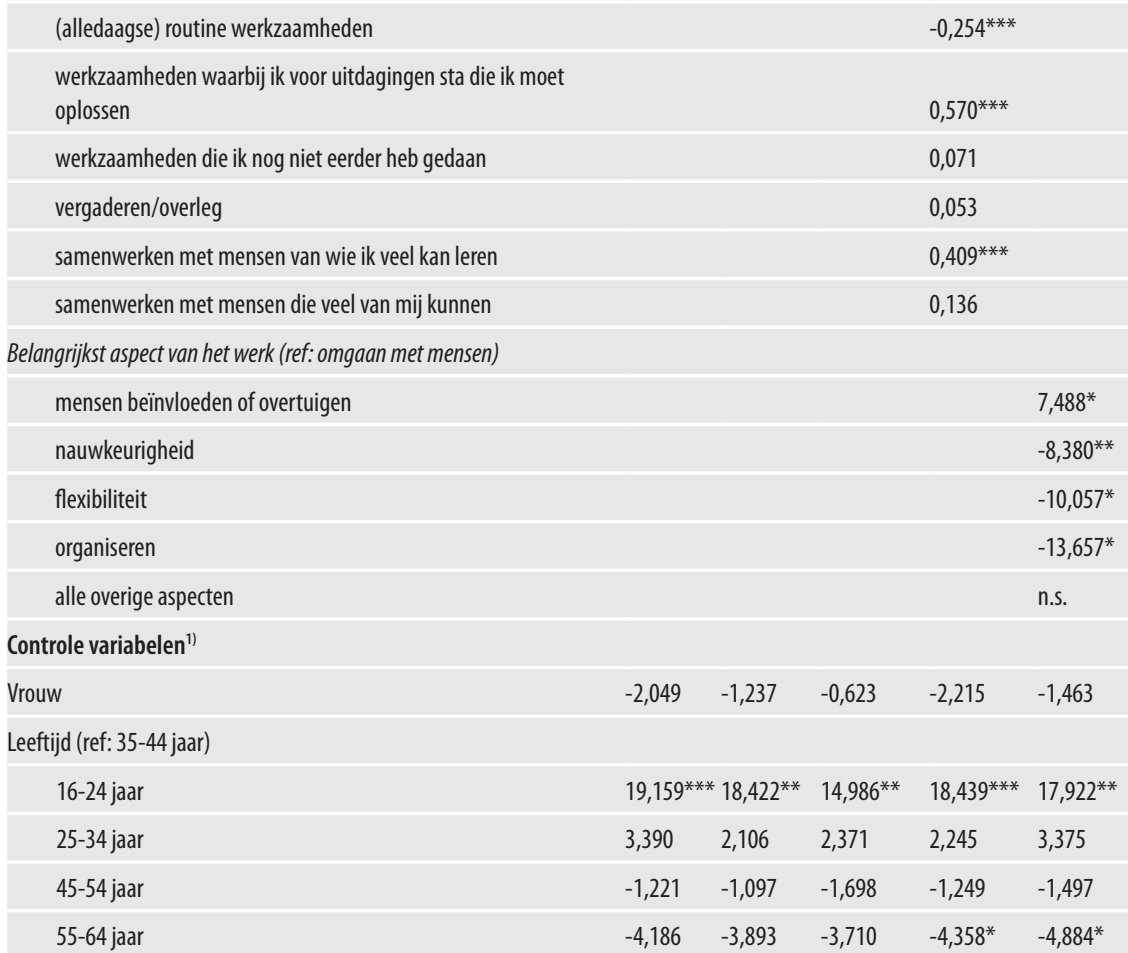


Tabel 2.4 (vervolg)

Relatie tussen de aard van de werkzaamheden en de mate waarin men informeel leert, 2010 (coëfficiënten uit OLS model)

\begin{tabular}{|c|c|c|c|c|c|}
\hline & (1) & (2) & (3) & (4) & (5) \\
\hline \multicolumn{6}{|l|}{ Opleiding (ref: mbo) } \\
\hline bo/vmbo & 0,093 & $-0,454$ & 0,542 & 1,335 & 0,575 \\
\hline havo/vwo & $-0,883$ & $-0,619$ & $-1,048$ & $-0,613$ & $-0,930$ \\
\hline hbo & $5,644^{* *}$ & 4,076 & 1,224 & $4,338^{*}$ & $5,243^{*}$ \\
\hline wo & $10,257^{* * *}$ & $8,888^{* * *}$ & $5,529^{*}$ & $6,211^{* *}$ & $8,720^{* * *}$ \\
\hline Constante term & $23,016^{* * *}$ & $23,533^{* * *}$ & $26,158^{* * *}$ & $20,817^{* * *}$ & $25,363^{* * *}$ \\
\hline Adjusted-R-kwadraat & 0,047 & 0,068 & 0,121 & 0,165 & 0,054 \\
\hline N & 888 & 882 & 883 & 883 & 888 \\
\hline
\end{tabular}

Tabel 2.4 geeft een overzicht van de uitkomsten van de regressieanalyse voor de relatie tussen de aard van de werkzaamheden die iemand verricht en het percentage van de werktijd dat besteed wordt aan taken waarvan men kan leren. Daaruit blijkt dat het uitvoeren van organiserende taken positief samenhangt met informeel leren (model 2). Naarmate men meer routine werkzaamheden (model 3 en model 4 ) uitvoert leert men ook significant minder van het werk. Daarentegen gaat samenwerken, werk dat berust op intuïtie en moeilijk werk gepaard met meer informeel leren (model 4). Ook de tijd die werkenden besteden aan werkzaamheden waarbij men voor uitdagingen staat die men moet oplossen is positief gerelateerd aan informeel leren (model 4). Ook blijkt uit dit model dat het samenwerken met mensen waarvan men veel kan leren ook leidt tot meer informeel leren, maar dit geldt niet voor het samenwerken met mensen die van jou veel kunnen leren. Model 5 laat zien dat: werkenden die 'mensen beïnvloeden' opgeven als het belangrijkst aspect van hun werk ook meer werkzaamheden hebben waarvan zij kunnen leren. Werkenden die 'nauwkeurigheid', 'flexibiliteit', of 'organiseren' als belangrijkste aspect van hun werk opgeven besteden minder tijd aan activiteiten waarvan zij kunnen leren. Het verschil in kenmerken van het werk (model 3) tussen hoger en lager opgeleiden kunnen de verschillen in informeel leren naar opleidingsniveau voor een deel, maar niet helemaal, verklaren.

\subsection{Aspecten van werk en kennisontwikkeling}

We besluiten dit hoofdstuk met een analyse van de relatie tussen de aard van werkzaamheden en de kennisontwikkeling. Bij de analyses wordt tevens gecontroleerd voor deelname aan training in de afgelopen twee jaar en informeel leren. De resultaten worden gerapporteerd in tabel 4.5 en laten ten eerste zien dat de kennisontwikkeling van werkenden samenhangt met zowel het formele als het informele leren. 
Werkenden die in de afgelopen twee jaar een training of cursus hebben gevolg ervaren een sterkere kennisontwikkeling. Ook het percentage van de werktijd dat aan werkzaamheden wordt besteed waarvan met kan leren is geassocieerd met een sterkere kennisontwikkeling.

\section{Tabel 2.5}

Relatie tussen de aard van de werkzaamheden en de kennisontwikkeling, 2010 (coëfficiënten uit OLS model)
(1)
(2)
(3)
(4)

\section{Verklarende variabelen}

Mate waarin werk berust op uitvoeren dan wel organiseren van taken

uitvoerend werk 0,788

organiserende taken

Kenmerken van het werk (zoals besproken in figuur 3.3)

routine werk

$1,029^{* *}$

moeilijk werk

0,092

intuitie

$1,149^{* *}$

samenwerken

$-0,054$

Percentage van de werktijd besteed aan:

\begin{tabular}{|c|c|c|c|c|c|}
\hline (alledaagse) routine werkzaamheden & & & & \multicolumn{2}{|l|}{$0,057^{*}$} \\
\hline $\begin{array}{l}\text { werkzaamheden waarbij ik voor uitdagingen sta die il } \\
\text { oplossen }\end{array}$ & & & & \multicolumn{2}{|l|}{$-0,103$} \\
\hline werkzaamheden die ik nog niet eerder heb gedaan & & & & \multicolumn{2}{|l|}{0,000} \\
\hline vergaderen/overleg & & & & \multicolumn{2}{|l|}{0,138} \\
\hline samenwerken met mensen van wie ik veel kan leren & & & & \multicolumn{2}{|l|}{$-0,041$} \\
\hline samenwerken met mensen die veel van mij kunnen & & & & \multicolumn{2}{|l|}{$-0,044$} \\
\hline \multicolumn{6}{|l|}{ Belangrijkste aspect van het werk (ref: omgaan met mensen) } \\
\hline flexibiliteit & & & & & $-6,178^{*}$ \\
\hline commercieel inzicht & & & & & $8,641^{* *}$ \\
\hline fysieke conditie en kracht & & & & & $-32,229^{* *}$ \\
\hline creativiteit & & & & & $31,509^{* * *}$ \\
\hline buitenlandse talen & & & & & $-9,030^{*}$ \\
\hline alle overige aspecten & & & & & n.s. \\
\hline Training gevolgd in afgelopen 2 jaar & $2,314^{* *}$ & $1,980^{* *}$ & $2,789^{* * *}$ & $2,456^{* *}$ & $2,230^{* *}$ \\
\hline Informeel leren & $0,074^{* * *}$ & $0,070^{* * *}$ & $0,083^{* * *}$ & $0,094^{* * *}$ & $0,073^{* * *}$ \\
\hline \multicolumn{6}{|l|}{ Controle variabelen ${ }^{1)}$} \\
\hline Vrouw & $2,523^{* *}$ & $2,619^{* *}$ & $2,587^{* *}$ & $2,839^{* *}$ & $2,286^{*}$ \\
\hline
\end{tabular}


Tabel 2.5 (vervolg)

Relatie tussen de aard van de werkzaamheden en de kennisontwikkeling, 2010 (coëfficiënten uit OLS model)

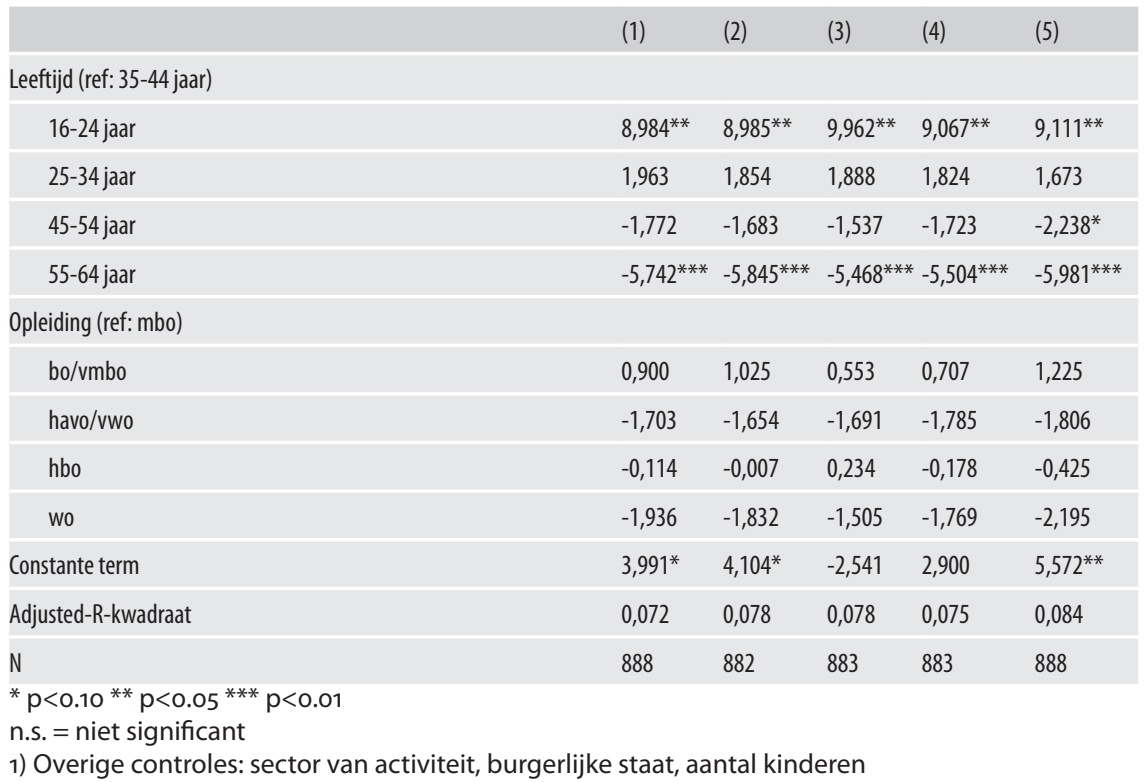

Tabel 2.5 laat verder zien dat werkenden waarvaan de werkzaamheden eerder op het organiseren van het werk een hogere mate van kennisontwikkeling rapporteren. Dit geldt ook naarmate het werk eerder op intuïtie berust dan op kennis. Ook werknemers die commercieel inzicht en creativiteit rapporteren als belangrijkste aspecten van het werk vertonen een hogere kennisontwikkeling (vergeleken met omgaan met mensen). Daar staat tegenover dat aspecten van het werk zoals buitenlandse talen, fysieke conditie en kracht, en flexibiliteit geassocieerd worden met een lager kennisontwikkeling. Opmerkelijk is dat ook het uitoefen van routine werkzaamheden gepaard gaat met meer kennisontwikkeling. ${ }^{\mathrm{I}}{ }^{8}$

I8. Het effect is echter niet significant wanneer in het model niet gecontroleerd wordt voor foormeel en informeel leren. 



\section{Wie traint en wie leert?}

Naast opleidingsniveau en de aard van het werk kan ook persoonlijkheid van belang zijn voor formeel en informeel leren. Uit onderzoek is gebleken dat persoonlijkheidskenmerken van grote invloed zijn op veel van de beslissingen die mensen nemen (Borghans e.a., 2008b). In dit hoofdstuk gaan wij in op de vraag in welke mate deze persoonlijkheidkenmerken bepalend zijn voor de deelname aan cursussen en trainingen en het informele leren op het werk. Wij gaan in het bijzonder in op de rol van de vijf basisdimensies van iemands persoonlijkheid (de Big Five), de intrinsieke motivatie om te leren, zelfregulatie, risicoattitude en tijdoriëntatie. Deze variabelen worden in Bijlage A toegelicht.

De analyses in dit hoofdstuk beperken zich tot de 2004 en 20 oro golven van de $R O A$ Levenslang Leren Enquête. Wij gaan achtereenvolgens in op de relatie tussen persoonlijkheidkenmerken en I) trainingsparticipatie, 2) informeel leren, en 3) de bereidheid om zich te scholen. In de afsluitende paragraaf wordt stilgestaan bij scholing door ouderen.

\subsection{Trainingsdeelname en persoonlijkheid}

\section{Trainingdeelname door werkenden}

Tabel 3.I laat de resultaten zien van econometrische analyses voor de determinanten van trainingsdeelname in de afgelopen twee jaar. Het laat zien dat de kans op deelname aan training positief samenhangt met openheid voor ervaring. Het hangt negatief samen met neuroticisme maar het effect is alleen zwak significant (significant op II\%). Het man-vrouw-verschil in trainingsparticipatie (model I) wordt minder significant wanneer gecontroleerd wordt voor persoonlijkheid, maar blijft wel nagenoeg even groot. De lagere trainingsparticipatie onder oudere werknemers (55-64 jaar) kan niet worden verklaard uit verschillen in persoonlijkheid. Economische motieven spelen een belangrijke rol bij oudere werknemers; zij lopen tegen het einde van hun carrière en de tijdshorizon voor het terugverdienen van de trainingsinvestering is ongeacht hun motivatie en persoonlijkheid - kort.

Verder blijken zelfregulatie en intrinsieke motivatie om te trainen positief gecorreleerd met de trainingsparticipatie. Ook als gecontroleerd wordt voor het type taken 
dat men doet op het werk (zoals in hoofdstuk 2 besproken) blijft dit effect bestaan. Voorkeuren zoals risicoaversie en tijdoriëntatie blijken niet gecorreleerd te zijn met trainingsdeelname.

\section{Tabel 3.1}

Kenmerken van werkenden die in de afgelopen twee jaar een training hebben gevolgd (probit coëfficiënten), werkenden, 2004 en 2010
(1)
(2)
(3)

\section{Verklarende variabelen}

Big Five

\begin{tabular}{|l|c|}
\hline open voor nieuwe ervaringen & $0,090^{* * *}$ \\
\hline zorgvuldig & 0,011 \\
\hline extravert & 0,048 \\
\hline meegaand & 0,011 \\
\hline neurotisch & $-0,052$ \\
\hline
\end{tabular}

Zelfregulatie

$0,095^{* *}$

Intrinsieke motivatie

$0,263^{* * *}$

Risicoattitude

0,040

Tijdoriëntatie

$-0,040$

\section{Controle variabelen ${ }^{1)}$}

Vrouw

$-0,127^{*}$

$-0,111$

0,021

Leeftijd (ref: 35-44 jaar)

\begin{tabular}{|clll|}
\hline 16-24 jaar & $-0,072$ & $-0,063$ & $-0,288$ \\
\hline $25-34$ jaar & 0,122 & 0,117 & $-0,141$ \\
\hline $45-54$ jaar & $-0,080$ & $-0,072$ & $-0,036$ \\
\hline $55-64$ jaar & $-0,300^{* * *}$ & $-0,302^{* * *}$ & $-0,176$ \\
\hline Opleiding (ref: mbo) & & & \\
\hline bo/vmbo & $-0,107$ & $-0,108$ & $-0,055$ \\
\hline havo/vwo & $-0,090$ & $-0,120$ & $-0,014$ \\
\hline hbo & $0,273^{* * *}$ & $0,225^{* * *}$ & $0,275^{* *}$ \\
\hline wo & $0,262^{* * *}$ & $0,201^{* *}$ & $0,326^{* *}$ \\
\hline Constante term & 0,161 & 0,172 & 0,192 \\
\hline Pseudo-R-kwadraat & 0,041 & 0,049 & 0,067 \\
\hline N & 2.223 & 2.223 & 876 \\
\hline
\end{tabular}

${ }^{*} p<0.10^{* *} p<0.05{ }^{* * *} p<0.01$

1) Overige controles: sector van activiteit, burgerlijke staat, aantal kinderen, jaardummy voor 2004 (in model 1 en 2) 
Zowel intrinsieke motivatie om te leren als zelfregulatie blijken significant te verschillen naar opleidingsniveau: hoe hoger het opleidingsniveau, hoe sterker is de intrinsieke motivatie om te leren en de mate van zelfregulatie. ${ }^{19}$ Dit roept de vraag op in welke mate persoonlijkheidskenmerken vergelijkbare effecten hebben voor werknemers met verschillende opleidingsniveaus. Nader analyse van de determinanten van scholingsdeelname naar opleidingsniveau (niet gerapporteerd in tabel) laat zien dat bij de laagopgeleiden (vbo) openheid voor ervaring positief correleert met deelname aan scholing. Intrinsieke motivatie en zelfregulatie hebben gezamenlijk een significant effect op de deelname aan scholing door laagopgeleiden: dus laagopgeleiden met voldoende mate van motivatie zijn te stimuleren voor deelname aan scholing. Voor werknemers met een havo/vwo- of mbo-diploma zijn zelfregulatie, motivatie en extraversie positief gecorreleerd met scholingsdeelname. Bij hoogopgeleiden (hbo of hoger) zijn openheid voor ervaring en intrinsieke motivatie positief gecorreleerd met scholingsdeelname. Neuroticisme, daarentegen, is bij hoogopgeleiden negatief gecorreleerd met training.

\section{Trainingdeelname door werklozen en inactieven ${ }^{20}$}

Een vergelijkbare analyse voor de determinanten van trainingsparticipatie door werklozen en inactieven wordt gerapporteerd in tabel C.I in de bijlage. Het laat zien dat openheid voor ervaring positief samenhangt met de kans op deelname aan scholing. Zorgvuldigheid, daarentegen, hangt negatief samen met de kans op scholing voor niet-werkenden. Intrinsieke motivatie om te leren hangt eveneens positief samen met training.

Van belang is te noteren dat werklozen vaker aan scholing deelnemen. Voor hen is de afstand tot de arbeidsmarkt kleiner. Verder blijkt dat niet-werkenden vrouwen vaker aan scholing deelnemen dan niet-werkenden mannen, maar dat niet-werkende 55-plussers minder vaak aan training deelnemen: voor hen is de tijdshorizon om de trainingsinvestering terug te verdienen korter, vergeleken met jongeren. ${ }^{2 \mathrm{I}}$

\section{Nooit trainen}

Hoofdstuk I liet zien dat ongeveer een op de vijf werknemers nooit aan training deelneemt. Wij gaan in deze paragraaf dieper in op de kenmerken van de groep respondenten die nooit training heeft gevolgd, en vergelijken deze met werknemers die ooit wel training hebben gevolgd (in de afgelopen twee jaar of langer geleden). Tabel 3.2

I9. Werkenden blijken overigens ook hoger te scoren op intrinsieke motivatie en zelfregulatie dan nietwerkenden.

20. In dit hoofdstuk, behalve in paragraaf 3.4, laten wij studenten en scholieren en persoenen die met (vervroegd) pensioen zijn gegaan buiten beschouwing. Inactieven zijn dus huisvrouwen, huismannen, arbeidsongeschikten en vrijwilligers.

2I. Het insignificant worden van het effect voor ouderen in de derde kolom is het gevolg van het kleiner aantal cases, niet van de controle voor motivatie, zelfregulatie, risicoattitude en tijdoriëntatie. 
laat zien welke persoonlijkheidskenmerken samenhangen met het nooit deelnemen aan cursussen of trainingen.

Tabel 3.2

Kenmerken van werkenden die nog nooit een training hebben gevolgd (probit coëfficiënten), (referentie: ooit training gevolgd), 2004 en 2010

(1)

\section{Verklarende variabelen}

Big Five

open voor nieuwe ervaringen

zorgvuldig

extravert

meegaand

neurotisch

Zelfregulatie

Intrinsieke motivatie

Risicoattitude

Tijdoriëntatie

Controle variabelen ${ }^{1)}$

Vrouw

Leeftijd (ref: 35-44 jaar)

\begin{tabular}{|c|c|c|c|}
\hline 16-24 jaar & $0,494^{* *}$ & $0,435^{* *}$ & $0,695^{*}$ \\
\hline 25-34 jaar & 0,023 & 0,042 & 0,206 \\
\hline 45-54 jaar & $-0,130$ & $-0,142^{*}$ & $-0,091$ \\
\hline 55-64 jaar & $-0,033$ & $-0,026$ & $-0,152$ \\
\hline \multicolumn{4}{|c|}{ Opleiding (ref: mbo) } \\
\hline bo/vmbo & $0,218^{* *}$ & $0,206^{* *}$ & 0,162 \\
\hline havo/vwo & $0,269^{* *}$ & $0,301^{* *}$ & 0,111 \\
\hline hbo & $-0,283^{* * *}$ & $-0,246^{* *}$ & $-0,258$ \\
\hline wo & $-0,138$ & $-0,068$ & $-0,180$ \\
\hline Istante term & $-0,835^{* * *}$ & $-0,833^{* * *}$ & $-0,816^{* * *}$ \\
\hline udo-R-kwadraat & 0,048 & 0,061 & 0,099 \\
\hline & 2.223 & 2.223 & 876 \\
\hline
\end{tabular}

1) Overige controles: sector van activiteit, burgerlijke staat, aantal kinderen, jaardummy voor 2004 (in model 1 en 2)

Van de Big Five persoonlijkheidskenmerken hangen zowel openheid voor ervaring als zorgvuldigheid negatief samen met de kans om nooit training te hebben gevolgd. Daarnaast blijken intrinsieke motivatie om te trainen en zelfregulatie ook negatief 
samen te hangen met de kans om nooit aan trainingsactiviteiten te hebben deelgenomen. Dit is het spiegelbeeld van de resultaten uit tabel 2.I. De vraag is of het een gebrek aan zelfregulatie of motivatie is dat er voor zorgt dat werknemers nooit in training investeren of dat het te maken heeft met het soort taken dat men heeft op het werk? Dit blijkt niet het geval. Na controle voor tijd besteed aan zes taken op het werk (zoals besproken in tabel 2.I) blijken de effecten van zelfregulatie en motivatie even sterk en significant.

Vooral de jongste werknemers blijken nog nooit aan training te hebben deelgenomen, en controleren voor persoonlijkheid en voorkeuren veranderd daar niets aan. Dit heeft er mee te maken dat naarmate de leeftijd hoger is, men vaker in de gelegenheid is geweest aan scholing deel te nemen.

Bij laagopgeleiden heeft alleen openheid voor ervaring een negatief associatie met het nooit deelnemen aan scholing (niet gerapporteerd in tabel). Bij middelbaar opgeleiden heeft risicoattitude naast de hierboven (tabel 3.3) besproken factoren, ook een negatieve correlatie met de kans om nooit in scholing te investeren. In tegenstelling tot het effect dat op de hele steekproef is gevonden, is zelfregulering bij hoogopgeleiden niet gecorreleerd met de kans om nooit aan scholing deel te nemen.

De in tabel 3.2 gerapporteerde analyse is herhaald voor de werklozen en inactieven, waarbij wij ons hebben beperkt tot personen met enige arbeidsmarktervaring (minimaal 5 jaar gewerkt). De resultaten zijn weergegeven in tabel C. 2 in de bijlage en laten zien dat net als bij werkenden, de kans om nooit aan scholing te hebben deelgenomen negatief samenhangt met intrinsieke motivatie. Andere persoonlijkheidskenmerken hangen niet samen met de kans om nooit aan scholing te hebben deelgenomen. Deze kans is overigens kleiner voor werklozen dan voor inactieven.

\subsection{Informeel leren}

De relatie tussen de tijd besteed aan taken waarvan men kan leren en persoonlijkheid is weergegeven in tabel 3.3. Persoonlijkheidkenmerken uit de Big Five vertonen geen samenhang met informeel leren. Er is daarentegen wel sprake van een significante positieve relatie tussen intrinsieke motivatie en informeel leren: naarmate werkenden meer intrinsiek gemotiveerd zijn om te leren spenderen zij ook meer tijd aan taken waarvan zij kunnen leren. Daarnaast is er een zwak significant en positief effect van risicoattitude. Wanneer men controleert voor de tijd besteed aan specifieke taken op het werk (zoals besproken in tabel 2.I) zijn de effecten van intrinsieke motivatie en risicoattitude echter niet meer significant. Intrinsiek gemotiveerde mensen komen kennelijk in banen terecht die gepaard gaan met taken waarvan men meer kan leren. 
Tabel 3.3

Percentage van de tijd dat men spendeert aan taken waarvan men kan leren (coëfficiënten uit OLS model), werkenden, 2004 en 2010

(1)

(2)

(3)

\section{Verklarende variabelen}

Big Five

\begin{tabular}{lc} 
open voor nieuwe ervaringen & 0,942 \\
\hline zorgvuldig & $-0,534$ \\
\hline extravert & $-0,309$ \\
meegaand & 1,161 \\
\hline neurotisch & 0,032
\end{tabular}

Zelfregulatie

Intrinsieke motivatie

1,266

Risicoattitude

$2,494^{* *}$

Tijdoriëntatie

$1,840^{* *}$

$-0,505$

Controle variabelen ${ }^{11}$

Vrouw

$-1,720$

$-2,019$

$-2,088$

Leeftijd (ref: $35-44$ jaar)

\begin{tabular}{clll} 
16-24 jaar & $19,429^{* * *}$ & $19,264^{* * *}$ & $19,255^{* * *}$ \\
\hline 25-34 jaar & $4,047^{* *}$ & $3,766^{* *}$ & 2,385 \\
\hline 45-54 jaar & $-1,379$ & $-1,153$ & $-1,347$ \\
\hline 55-64 jaar & $-6,001^{* * *}$ & $-5,785^{* * *}$ & $-4,168$ \\
\hline $\begin{array}{l}\text { Opleiding (ref: mbo) } \\
\text { bo/vmbo }\end{array}$ & 1,392 & 1,316 & 0,129 \\
\hline havo/vwo & $-3,034$ & $-3,196$ & $-0,271$ \\
\hline hbo & $3,838^{* *}$ & $3,231^{*}$ & $4,805^{*}$ \\
\hline wo & $6,650^{* * *}$ & $5,776^{* * *}$ & $9,573^{* * *}$ \\
\hline Constante term & $24,802^{* * *}$ & $24,523^{* * *}$ & $23,336^{* * *}$ \\
Adjusted-R-kwadraat & 0,058 & 0,060 & 0,057 \\
\hline N & 2.121 & 2.121 & 876 \\
\hline * $<<0.10^{* *} p<0.05^{* * *} p<0.01$ & & & \\
\hline
\end{tabular}

r) Overige controles: Sector van activiteit, burgerlijke staat, aantal kinderen, jaardummy voor 2004 (in model I en 2) 


\subsection{Bereidheid tot het volgen van scholing en motivatie voor scholing}

\section{Bereidheid tot scholing in eigen tijd}

De mate waarin mensen deelnemen aan scholing en informeel leren wordt bepaald door hun eigen attitude maar ook door de mogelijkheden die de werkgever hiervoor geeft. Om deze twee facetten uit elkaar te kunnen halen is het van belang om ook de bereidheid tot scholingsdeelname als zodanig in kaart te brengen. In de 2010 ROA Levenslang Leren Enquête is daarom aan de respondenten gevraagd zich voor te stellen dat zij een tegoedbon (voucher) ontvangen ter waarde van $€$ I.Ooo die ze binnen een jaar kunnen gebruiken om een cursus te gaan volgen. Gevraagd wordt hoe waarschijnlijk de kans is dat men de cursus zou gaan volgen op een schaal van I (zeer onwaarschijnlijk) tot 5 (zeer waarschijnlijk). Onder werknemers in loondienst zijn twee random groepen gemaakt (zelfstandigen worden in deze analyse buiten beschouwing gelaten omdat zij eigen baas zijn). Aan de ene helft van de werknemers is verteld dat ze de voucher van de werkgever ontvangen. Aan de andere helft van de werknemers is verteld dat ze de voucher van de overheid ontvangen. Voor beide groepen geldt dat ze de cursus in eigen tijd moeten volgen en voorbereiden. Werklozen en inactieven hebben ook de vraag voorgelegd gekregen; zij ontvangen de voucher van de overheid. De antwoorden op deze vouchervraag geeft een indicatie van de bereidheid van respondenten om te investeren in hun menselijk kapitaal.

Naast de vraag naar de bereidheid om deze cursus in eigen tijd te volgen is ook gevraagd of men bereid zou zijn aan de cursus deel te nemen als de scholing tijdens werktijd wordt gevolgd in plaats van de eigen tijd (alleen voor werknemers in loondienst) en als een eigen bijdrage van de deelnemer wordt gevraagd. Deze twee varianten komen in de volgende twee paragrafen aan bod.

Tabel 3.4 geeft de verdeling weer van de waarschijnlijkheid van deelname aan de cursus voor vier groepen. Daaruit blijkt dat er bij de werknemers in loondienst geen significant verschil is in de kans dat de scholingsvoucher wordt besteed - oftewel de bereidheid om aan de scholing deel te nemen - tussen de twee gerandomiseerde groepen. Met andere woorden, onder werknemers maakt het voor de bereidheid om de voucher te gebruiken niet uit of deze via de werkgever of de overheid wordt verstrekt: de bereidheid tot scholing in even groot in beide groepen. De scholingsbereidheid van werklozen is niet significant verschillend van dat van werknemers. ${ }^{22}$ De scholingsbereidheid van inactieven is daarentegen significant lager dan dat van werknemers in loondienst (het verschil bedraagt gemiddeld genomen een halve punt op de schaal).

22. Opgemerkt moet worden dat de groep werklozen dat antwoord heeft gegeven op deze vraag slechts uit 40 personen bestaat. 
Tabel 3.4

Kans dat scholingsvoucher wordt besteed, 2010

\begin{tabular}{lcccc} 
& Werkend in loondienst & Werkloos & Inactief \\
& $\begin{array}{c}\text { voucher van } \\
\text { werkgever } \\
\%\end{array}$ & $\begin{array}{c}\text { voucher van } \\
\text { overheid } \\
\%\end{array}$ & $\begin{array}{c}\text { voucher van } \\
\text { overheid } \\
\%\end{array}$ & $\begin{array}{c}\text { voucher van } \\
\text { overheid } \\
\%\end{array}$ \\
\hline Zeer onwaarschijnlijk & 13 & 10 & 12 & 24 \\
\hline Een kleine kans & 8 & 10 & 2 & 15 \\
\hline $50-50$ & 20 & 23 & 8 & 16 \\
\hline Een grote kans & 27 & 31 & 48 & 24 \\
\hline Zeer waarschijnlijk & 33 & 26 & 30 & 21
\end{tabular}

Figuur 3.1

Motieven voor besteding scholingsvoucher, werknemers naar opleidingsniveau, 2010

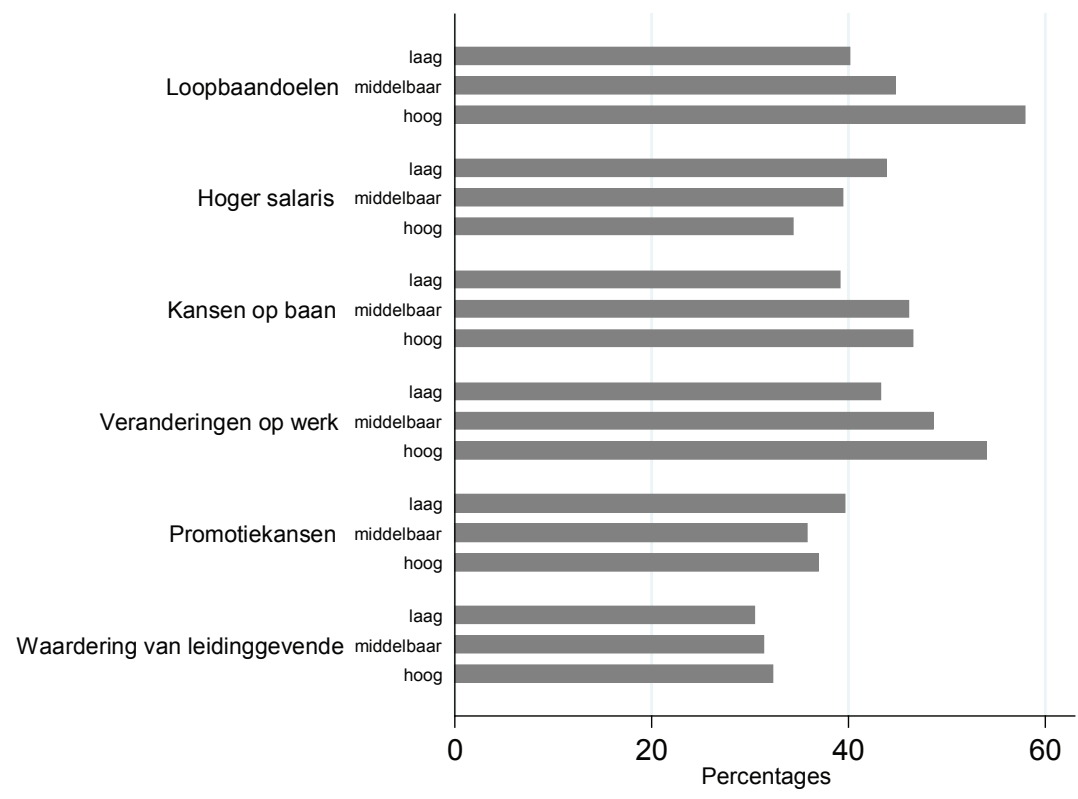

De redenen waarom men de scholingsvoucher waarschijnlijk zou gebruiken wordt voor werknemers in figuur 3.I uiteengezet. Daaruit blijkt dat het vergroten van de baankansen, het bereiken van loopbaandoelen en veranderingen op het werk belangrijke motieven zijn om de voucher te gebruiken. Opmerkelijk is het feit dat voor deze motieven het percentage dat aangeeft er met het motief eens te zijn oploopt met het opleidingsniveau. Voor laagopgeleiden speelt het verkrijgen van een hoger loon een belangrijkere rol dan voor hoogopgeleiden. Indien gekeken wordt naar de respondenten die de voucher van de werkgever krijgen, dan blijkt dat het motief "het krijgen 
van waardering van mijn leidinggevende" vaker door hoogopgeleiden wordt opgenoemd. Het verschil naar opleidingsniveau is niet significant, maar het suggereert dat sociaal wenselijk gedrag een even vaak voorkomend motief is voor deelname aan scholing bij hoog-als bij laagopgeleiden. Vrouwen rapporteren een grotere kans dat ze de scholingsvoucher gaan besteden dan mannen, terwijl de laagst opgeleiden de kleinste scholingsbereidheid vertonen (tabel 3.5). De kans dat de scholingsvoucher wordt besteed is significant lager onder 55-plussers, maar ook voor jongeren tussen de 16 en 24 jaar. Wij komen uitgebreid terug op de scholingsdeelname en scholingsbereidheid van ouderen in de laatste paragraaf van dit hoofdstuk. Het is interessant te noteren dat - wanneer gecontroleerd wordt voor achtergrondkenmerken - de waarschijnlijkheid van gebruikt van de voucher significant lager is voor werknemers die de voucher van de overheid krijgen dan voor werknemers die de voucher van de werkgever krijgen. Kennelijk speelt het feit dat de training door de werkgever wordt aangeboden een belangrijke rol in de trainingsbeslissing. De kans dat de voucher wordt gebruikt is onder niet-werkenden kleiner dan onder werknemers.

De waarschijnlijkheid waarmee de voucher wordt gebruikt hangt positief samen met openheid en meegaandheid. Daarnaast spelen intrinsieke motivatie en risicoattitude een significante en positieve rol. Zelfs na controle voor verschillen in intrinsieke motivatie en andere kenmerken van persoonlijkheid blijkt het man-vrouw verschil in de kans dat de voucher wordt besteed significant te zijn; vrouwen geven vaker aan van de voucher gebruik te zullen maken. Voor werklozen vinden wij een significante hogere bereidheid om de voucher te gebruiken, zelfs na controle voor persoonlijkheid. De scholingsbereidheid van inactieven is daarentegen significant lage.

Mensen met hoge opportuniteitskosten ('s avonds liever iets anders doen, te moe zijn, of geen tijd kunnen vrij maken) en examenangst (het eng vinden om weer examen te moeten doen) blijken minder bereid te zijn om aan scholing deel te nemen. ${ }^{23}$

De analyse van de kans op besteding van de voucher uit tabel 3.5 is herhaald voor elke groep afzonderlijk om te testen of de beschreven patronen verschillend zijn naar gelang de voucher door de overheid dan wel de werkgever wordt aangeboden. De correlatie tussen persoonlijkheid en de waarschijnlijkheid dat de scholingsvoucher wordt besteed blijkt inderdaad verschillend tussen de groepen (tabel C.3 in de bijlage).

23. Deze resultaten zijn niet in de tabel opgenomen. 
Tabel 3.5

Kenmerken van respondenten die scholingsvoucher gaan besteden (ordered probit model), 2010

(1)

\section{Verklarende variabelen}

Big Five

\begin{tabular}{|lc|}
\hline open voor nieuwe ervaringen & $0,119^{* * *}$ \\
\hline zorgvuldig & $-0,044$ \\
\hline extravert & $-0,007$ \\
\hline meegaand & $0,107^{* * *}$ \\
\hline neurotisch & 0,007 \\
\hline
\end{tabular}

Zelfregulatie

Intrinsieke motivatie

Risicoattitude

Tijdoriëntatie

(2)

(3)

\section{Controle variabelen ${ }^{1)}$}

Vrouw

Leeftijd (ref: 35-44 jaar)

\begin{tabular}{l}
$16-24$ jaar \\
$25-34$ jaar \\
\hline $45-54$ jaar \\
$55-64$ jaar
\end{tabular}

Opleiding (ref: mbo)

bo/vmbo

hbo

wo

$\begin{array}{lll}-0,450^{* * *} & -0,431^{* * *} & -0,286^{* * *} \\ -0,122 & -0,137 & -0,005 \\ 0,071 & 0,009 & 0,030 \\ 0,222^{*} & 0,115 & 0,175\end{array}$

Groepen (ref: werknemer/voucher van werkgever)

\begin{tabular}{llll} 
werknemer / voucher van overheid & $-0,114$ & $-0,127^{*}$ & $-0,093$ \\
\hline werkloos / voucher van overheid & $0,375^{* *}$ & $0,380^{* *}$ & $0,410^{* *}$ \\
inactief / voucher van overheid & $-0,334^{* * *}$ & $-0,348^{* * *}$ & $-0,148$ \\
\hline Constante term & $0,478^{* * *}$ & $0,494^{* * *}$ & $0,782^{* * *}$ \\
Pseudo-R-kwadraat & 0,048 & 0,057 & 0,121 \\
N & 1.145 & 1.145 & 1.071
\end{tabular}

${ }^{*} p<0.10{ }^{* *} p<0.05$ *** $p<0.01$

1) Overige controles: burgerlijke staat en aantal kinderen. Daarnaast bevat het model 4 coëfficiënten voor de drempelwaardes van de latente afhankelijke variabele.

Voor alle groepen is intrinsieke motivatie positief gecorreleerd met de kans op besteding van de scholingsvoucher. Voor werknemers die de voucher van de werkgever 
krijgen is meegaandheid positief en zorgvuldigheid negatief gerelateerd met de waarschijnlijkheid van gebruik van de voucher. Het positief effect van meegaandheid zou kunnen betekenen dat juist degenen die geneigd zijn om mee te gaan in de wensen van de werkgever eerder bereid zijn om aan cursussen deel te nemen; om een goede verstandhouding met de werkgever te waarborgen. ${ }^{24}$ Een mogelijke verklaring voor het negatief effect van zorgvuldigheid is dat men dan het gevoel heeft weer meer van hetzelfde te zullen moeten leren. Een alternatieve verklaring is dat men al het gevoel alles goed te kunnen.

Voor werknemers die de voucher van de overheid krijgen is openheid voor ervaring positief gecorreleerd met de kans dat de voucher wordt benut. Openheid is onder de werklozen en inactieven ook significant. Dit suggereert dat een door de overheid aangeboden voucher vooral de leergierigen aanzet tot scholing, ongeacht of ze nu werkzaam zijn of niet. Maar, zoals bleek uit tabel 3.I, meer openheid gaat sowieso gepaard meet een hogere kans op deelname aan scholing.

Het verschil in het effect van openheid tussen de groepen zou kunnen betekenen dat leergierigen (of ze nu werkzaam zijn of niet) door de overheid gemotiveerd kunnen worden tot deelname aan scholing. Bij werknemers die de voucher van de werkgever krijgen spelen dergelijke leermotieven kennelijk een minder belangrijke rol, maar de bereidheid te doen wat de werkgever naar verlangt des te meer.

Voor werklozen en inactieven (die de voucher van de overheid ontvangen) is de risicoattitude ook positief gerelateerd aan de waarschijnlijkheid van deelname aan scholing: voor deze groep is een scholingsinvestering, bij gebrek aan een baan, niet zonder risico's, dus vooral degenen die risico's durven nemen zullen investeren.

Ten aanzien van de resultaten in tabel C. 3 is het verder interessant te noteren dat de grotere waarschijnlijkheid van vrouwen om de scholingsvoucher te gebruiken (zoals bleek uit tabel 3.5) vooral het gevolg is van de grotere trainingsbereidheid van nietwerkende vrouwen. Omdat de analyses controleren voor openheid (leergierigheid) dan wel voor intrinsieke motivatie om te leren wijst dit verschil er op dat vrouwen wellicht proberen een achterstand in de opbouw van hun menselijk kapitaal als gevolg van carrièreonderbrekingen te compenseren. Daarnaast is het opvallend dat de lagere bereidheid tot scholing in de groep 55-plussers vooral geldt voor werknemers die de voucher van de overheid ontvangen. Ook nadat gecontroleerd wordt voor verschillen in motivatie blijkt in deze groep het leeftijdsverschil in bereidheid tot scholing significant. Dit suggereert dat door de overheid gefaciliteerde scholing door middel van een

24. Het man-vrouw verschil in het gebruik van de voucher van de werkgever blijkt te worden overgenomen door het verschil in iemands meegaandheid. Vrouwen zijn gemiddeld genomen meer meegaand dan mannen. 
vouchersysteem minder effectief is voor het stimuleren van de trainingsparticipatie onder 55-plussers dan wanneer de voucher via de werkgever wordt aangeboden. ${ }^{25}$

\section{Bereidheid tot scholing in werktijd}

Als variant op de in de vorige paragraaf beschreven vouchervraag is aan werknemers in loondienst gevraagd hoe waarschijnlijk het is dat zij de voucher zouden gebruiken indien het volgen en voorbereiden van de cursus volledig onder werktijd zou kunnen plaatsvinden. Zoals verwacht mag worden is de bereidheid om de cursus te volgen in de baas z'n tijd (tabel 3.6) groter dan de bereidheid om de cursus te volgen in de eigen tijd (tabel 3.4). Dit komt doordat in dat geval zowel de directe kosten (de voucher) als de indirecte kosten (de tijdsinvestering) van de cursus volledig gedragen worden door de werkgever. Ongeveer $28 \%$ van de werknemers toont een grotere bereidheid om de cursus te volgen wanneer dit in werktijd kan. Daarbij maakt het niet uit of de voucher door de werkgever of door de overheid wordt aangeboden.

Tabel 3.6

Kans dat scholingsvoucher wordt besteed indien cursus gevolgd en voorbereid kan worden tijdens werktijd, werknemers in loondienst, 2010

\begin{tabular}{lcc} 
& \multicolumn{2}{c}{ Werknemers } \\
& voucher van werkgever & voucher van overheid \\
& $\%$ & $\%$ \\
\hline Zeer onwaarschijnlijk & 10 & 7 \\
\hline Een kleine kans & 7 & 6 \\
\hline $50-50$ & 15 & 30 \\
\hline Een grote kans & 23 & 37 \\
\hline Zeer waarschijnlijk & 46 & 20
\end{tabular}

Gemiddeld genomen is de waarschijnlijkheid van gebruik van de voucher groter wanneer de cursus in werktijd gevolgd en voorbereid wordt dan wanneer dit in eigen tijd moet. Welke kenmerken samenhangen met de grotere waarschijnlijkheid van het besteden van de voucher voor een cursus in de baas z'n tijd wordt onderzocht in tabel C. 4 in de bijlage. Van de Big Five persoonlijkheidskenmerken blijken openheid positief en zorgvuldigheid negatief samen te hangen met een grotere bereidheid om de voucher te besteden wanneer de cursus in de baas z'n tijd gevolgd kan worden. Werknemers met een sterke tijdsoriëntatie en intrinsiek gemotiveerde werknemers vertonen een grotere bereidheid om de cursus in de baas z'n tijd te volgen dan in eigen tijd. Daarnaast blijken werknemers met een sterke risicoattitude minder bereid om de cursus te volgen onder werktijd dan in de eigen tijd. Anders geformuleerd, werk-

25. Later, in hoofdstuk 4, laten wij zien dat ouderen hun employability in andere bedrijven lager inschatten dan jongeren, maar dat er geen leeftijdsverschil is in de ingeschatte kans op verlies van hun huidige baan. Dit suggereert dat ze bereid zijn om te investeren in de vaardigheden die van belang zijn voor hun huidige werk. 
nemers die risicoavers zijn, zijn meer bereid om de cursus te volgen wanneer dit in werktijd kan: zij proberen hiermee het investeringsrisico van de cursus af te wentelen op de werkgever.

Wat verder nog naar voren komt is dat het aanbieden van cursussen die in de baas z'n tijd gevolgd kunnen worden door middel van een voucher de cursusdeelname onder laagopgeleiden niet waarschijnlijker maakt dan wanneer de cursus in eigen tijd gevolgd zou moeten worden.

\section{Bereidheid tot scholing en eigen bijdrage in de kosten daarvan}

Als tweede variant op de vouchervraag is de waarschijnlijkheid om aan scholing deel te nemen gemeten wanneer een eigen bijdrage van $€ 250$ gevraagd wordt voor de cursus. De kans dat men dan aan scholing deel neemt is duidelijk lager wanneer een eigen bijdrage gevraagd wordt voor de cursus dan wanneer dit niet het geval is (vergelijk tabel 3.7 en tabel 3.4): ongeveer 50\% van de respondenten zegt dat er een kleine kans of dat het zelfs onwaarschijnljjk is dat zij de voucher zouden gebruiken.

\section{Tabel 3.7}

Kans dat scholingsvoucher wordt besteed indien een eigen bijdragen van $€ 250$ wordt gevraagd (cursus in eigen tijd), 2010

\begin{tabular}{lcccc} 
& \multicolumn{2}{c}{ Werkend in loondienst } & Werkloos & Inactief \\
voucher van & voucher van \\
werkgever & $\%$ & $\begin{array}{c}\text { overheid } \\
\%\end{array}$ & $\begin{array}{c}\text { voucher van } \\
\text { overheid } \\
\%\end{array}$ & $\begin{array}{c}\text { voucher van } \\
\text { overheid } \\
\%\end{array}$ \\
\hline Zeer onwaarschijnlijk & 30 & 24 & 24 & 42 \\
\hline Een kleine kans & 23 & 25 & 20 & 22 \\
\hline 50-50 & 24 & 29 & 27 & 22 \\
\hline Een grote kans & 16 & 15 & 22 & 13 \\
\hline Zeer waarschijnlijk & 7 & 7 & 7 & 2
\end{tabular}

In totaal rapporteert $58 \%$ van de respondenten een lagere waarschijnlijkheid van deelname aan de cursus wanneer er een eigen bijdrage wordt gevraagd van $€ 250$ dan wanneer dit niet het geval is. Uit een regressieanalyse blijkt dat de Big Five persoonlijkheidskenmerken gerelateerd zijn aan de deelname aan scholing wanneer er een eigen bijdrage betaald moet worden (zie tabel C.5 in de bijlage): meegaande types zijn minder bereid om aan cursussen deel te nemen wanneer er een eigen bijdrage gevraagd wordt; voor extraverte personen geldt het omgekeerde. Mensen die niet intrinsiek gemotiveerd zijn, zijn minder geneigd om de voucher te gebruiken wanneer er een eigen bijdrage wordt gevraagd dan wanneer dit niet het geval is. Dit betekent dat intrinsiek gemotiveerde respondenten er sowieso voor kiezen om de opleidingsvoucher te gaan besteden. Hetzelfde geldt voor mensen die over een grotere zelfregulatie beschikken. 
Leeftijd, geslacht, opleidingsniveau en het feit of de voucher van de werkgever of de overheid afkomstig is vertonen geen significante samenhang met het rapporteren van een kleinere kans op gebruik van de voucher wanneer een eigen bijdrage gevraagd wordt.

\section{Kenmerken cursus}

Aansluitend aan de vouchervraag zijn enkele vragen gesteld over het soort cursus waar men de voucher aan zou willen besteden. De cursus waar werknemers voor zouden kiezen is overwegend een cursus gericht op het verhogen van de vakspecifieke kennis (zie tabel C.6 in de bijlage). Daarna volgen cursussen rond effectief leiderschap, coachen en talen. Bij niet-werkenden zijn talencursussen het meest populair, daarna gevolgd door cursussen om de vakspecifieke kennis te vergroten en computer cursussen. Het gaat opvallend vaak om cursussen die niet gerelateerd zijn aan belangrijke aspecten van de huidige of de alternatieve baan (deze aspecten zijn aan bod gekomen in hoofdstuk 2): ongeveer tweederde van de respondenten geeft aan een cursus te willen volgen dat zij niet noemen als belangrijk voor de huidige of een alternatieve baan. Voor $43 \%$ van de respondenten is het behalen van een certificaat door de cursus (heel) erg belangrijk. Een certificaat wordt vaker als (heel) erg belangrijk gezien door laagopgeleiden (vbo) dan door hoogopgeleiden.

Voor respondenten die aangeven met enige waarschijnlijkheid aan de cursus te zullen deelnemen gaat de voorkeur overwegend uit naar een redelijk tot zeer specifieke cursus (ongeveer 60\%), waarbij het lijkt nauwelijks uit te maken of men werkt of niet of of men de voucher van de werkgever of de overheid ontvangt (tabel 3.8).

\section{Tabel 3.8}

Voorkeur voor een bepaalde cursus waaraan men voucher zou willen besteden, 2010

\begin{tabular}{lcccc} 
& Werkend in loondienst & Werkloos & Inactief \\
voucher van & voucher van \\
werkgever & $\%$ & $\begin{array}{c}\text { verheid } \\
\%\end{array}$ & $\begin{array}{c}\text { voucher van } \\
\text { overheid } \\
\%\end{array}$ & $\begin{array}{c}\text { voucher van } \\
\text { overheid } \\
\%\end{array}$ \\
\hline zeer specifiek onderwerp & 21 & 16 & 9 & 16 \\
\hline redelijk specifiek onderwerp & 43 & 42 & 50 & 39 \\
specifiek onderwerp maakt niet veel uit & 29 & 33 & 34 & 36 \\
specifiek onderwerp maakt helemaal niet uit & 8 & 9 & 7 & 9
\end{tabular}

Vergeleken met mbo'ers hebben vmbo'ers, havisten, vwo'ers minder vaak een specifiek onderwerp in gedachten waaraan zij de voucher zouden willen besteden (zie tabel C.7 in de bijlage). Respondenten die aangeven dat het zeer onwaarschijnlijk is dat zij de voucher zullen gaan gebruiken, kiezen voor een vrij specifieke cursus wanneer ze toch een keuze moeten maken. Respondenten die aangeven dat zij waarschijnlijk wel een cursus gaan volgen kiezen ook voor een specifieke cursus. Naarmate respondenten 
hoger scoren op openheid hebben zij ook vaker een duidelijke voorkeur voor een bepaalde training. Ook zelfregulatie en intrinsieke motivatie gaan gepaard met een voorkeur voor een bepaald soort cursus. Na controle voor persoonlijkheid blijken inactieven minder specifieke cursusonderwerpen in gedachten te hebben bij het besteden van de voucher. Werklozen hebben ook minder vaak een voorkeur voor een specifieke cursus (coëfficiënt is in absolute zin vergelijkbaar met dat van inactieven), maar deze relatie is niet significant. Dit laatste zou te maken kunnen hebben met het geringe aantal observaties.

\subsection{Training door ouderen}

Beleidsmatig vormen de oudere werknemers een interessante groep: het streven is om de hun arbeidsparticipatie omhoog te krijgen, en werkenden langer in het arbeidsproces te houden. Dit roept de vraag op hoe het gesteld is met de bereidheid van oudere werknemers om aan scholing deel te nemen. In deze paragraaf zoomen wij nader in op de groep 45-70 jarigen, ongeacht de arbeidsmarktstatus. De analyses zijn verder beperkt tot het jaar 2010 .

In figuur 3.2 staan trainingsdeelname in de afgelopen twee jaar, ${ }^{26}$ de waarschijnlijkheid om aan training deel te nemen (antwoord op de vouchervraag) en de intrinsieke motivatie om aan scholing deel te nemen afgebeeld naar leeftijd. Daarbij wordt naar zowel werkenden als niet-werkenden gekeken. De figuur laat zien dat de trainingsparticipatie afneemt als mensen ouder zijn dan 54 jaar, maar dat de bereidheid tot scholing en motivatie al afnemen als mensen ouder zijn dan 34 jaar (figuur 3.2).

26. Dit is vergelijkbaar met de data in figuur I.2. In figuur I.2 zijn de percentages gepresenteerd voor werkenden alleen en de lijnen zijn gesmoothed. 


\section{Figuur 3.2}

Trainingsparticipatie, bereidheid tot scholing en intrinsieke motivatie om te trainen, naar leeftijd (werkenden en niet werkenden), 2010

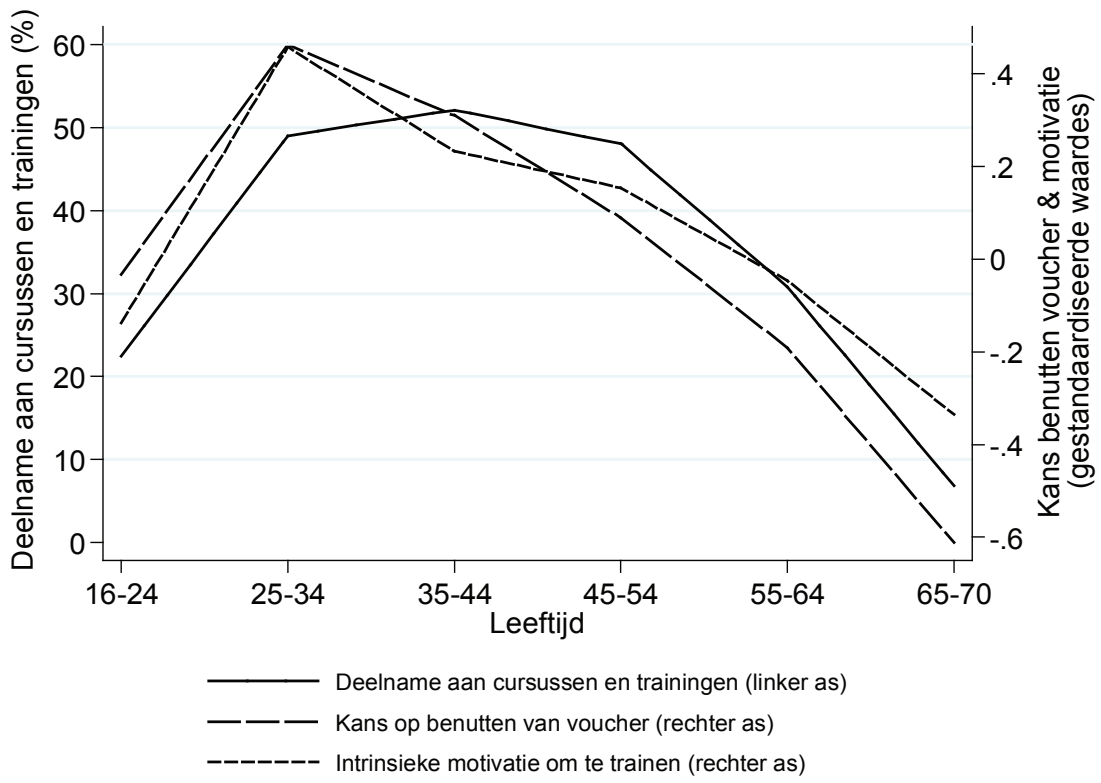

Zoals tabel 3.9 laat zien is de trainingsparticipatie van ouderen met een baan toch substantieel. Ongeveer de helft van de 45-64 jarigen heeft in de afgelopen twee jaar een cursus gevolgd. Een op de vijf heeft nog nooit een training gevolgd. Onder de niet werkende ouderen is de trainingsparticipatie aanzienlijk lager en ongeveer een op de drie heeft nooit een training gevolgd.

Tabel 3.9

Trainingdeelname van ouderen, naar leeftijd en arbeidsmarktstatus, 2010

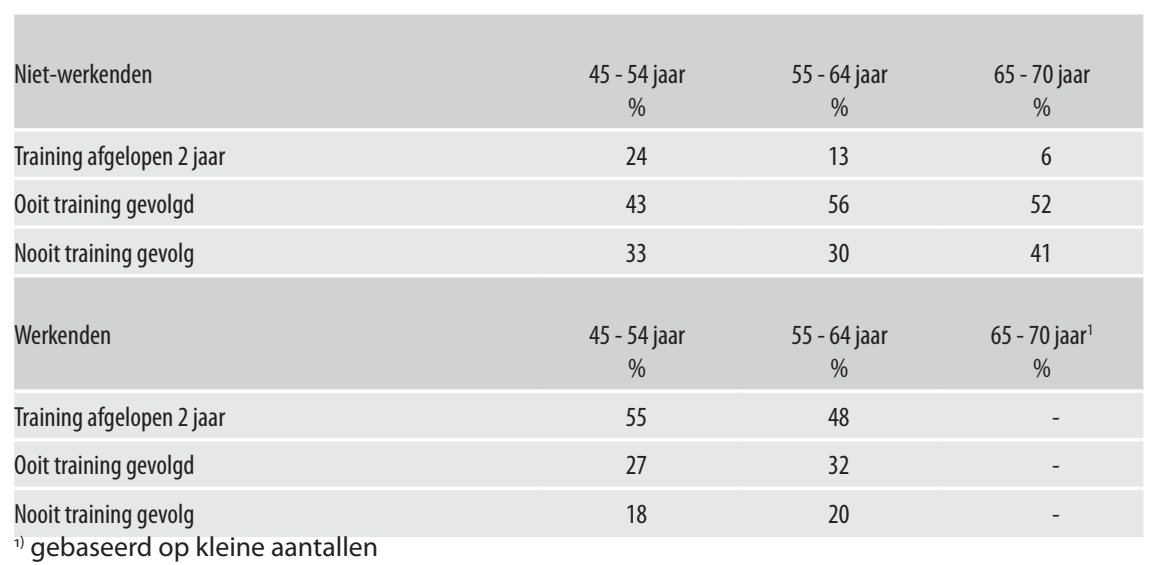


Tabel 3.Io laat de uitkomsten zien van econometrische analyses voor de relatie tussen persoonlijkheidskenmerken en trainingsparticipatie, de kans op het besteden van de scholingsvoucher en informeel leren. Onder 45-plussers, gaat neuroticisme gepaard met een kleinere kans om training te hebben gevolgd in de afgelopen twee jaar (dit was niet significant voor de gehele steekproef van werkenden), maar openheid correleert positief met de trainingsparticipatie. Intrinsieke motivatie gaat eveneens gepaard met een significante grotere kans om scholing te volgen.

Openheid en meegaandheid correleren positief met de kans dat de scholingsvoucher door 45 plussers wordt gebruikt. Dit geldt ook voor intrinsieke motivatie. Zorgvuldigheid daarentegen correleert negatief met de kans op het benutten van de voucher. Ook de risicoattitude hangt positief samen met de kans op benutten van de voucher. Dit effect van risicoattitude is volledig toe te schrijven aan niet werkende 45-plussers; voor hun is investeren in scholing immers een risicovolle investering.

Bij de werkenden van 45 jaar of ouder blijkt alleen de intrinsieke motivatie en risicoattitude positief samen te hangen met de tijd die waarin ze informeel leren op het werk.

Tabel 3.10

Kenmerken van ouderen (45-70 jaar) ${ }^{1)}$ die doorleren, werkenden en niet-werkenden, 2010

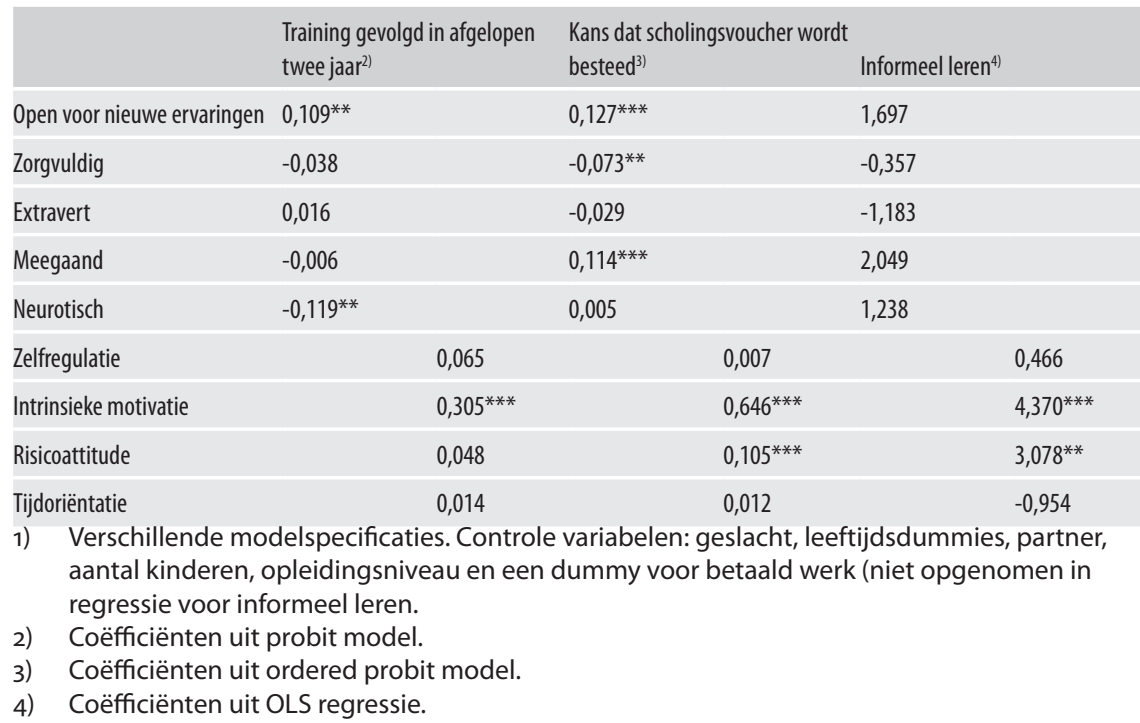

Over het algemeen kan worden gesteld dat werkende 45-plussers, vergeleken met jongere werknemers, minder vaak cursussen volgen die gericht zijn op vakspecifieke kennis of het omgaan met mensen, maar eerder cursussen volgen op het gebied van communiceren en coaching. 45-plussers zonder baan volgen in vergelijking tot jongeren vaker cursussen gericht op het omgaan met computers en minder vaak buitenlandse talencursussen. 



\section{Ervaring, opbouw van menselijk kapitaal en mobiliteit}

\subsection{Ervaring}

In de ene functie is het hebben van ervaring belangrijker dan in de andere functie. Om meer inzicht te krijgen in het belang van het hebben van ervaring voor de functies waarin de werkzame bevolking werkzaam zijn, wordt in deze paragraaf achtereenvolgens ingegaan op de vraag: of ervaring het werk gemakkelijker maakt en de vraag in welke mate werkenden in hun werk merken dat ze een tekort aan ervaring hebben.

\section{Maakt ervaring het werk gemakkelijker?}

Om de vraag of ervaring het werk gemakkelijker maakt te kunnen beantwoorden kijken we naar de mate waarin zich op het werk situaties voordoen die werknemers gemakkelijk zelf oplossen, terwijl zij vroeger, toen ze net werkzaam waren in hun huidige functie, daar lang mee bezig zouden zijn geweest of om advies moesten vragen. Figuur 4.I laat zien dat zowel bij laagopgeleiden als bij middelbaar en hoogopgeleiden meer dan tweederde van de werkenden aangeeft dat ze nu gemakkelijker problemen kunnen oplossen dan toen ze nog onervaren waren in hun werk. Op alle opleidingsniveaus is dit bij ruim 35\% van de werkenden zelfs (zeer) vaak het geval. Het hebben van meer werkervaring blijkt echter het belangrijkst te zijn voor hoger opgeleiden. Deze geven significant minder vaak aan dat ze nooit of zelden situaties op het werk meemaken die ze nu gemakkelijker oplossen dan vroeger. Dit duidt er op dat het werk van hoogopgeleiden vaker werkzaam zijn in een baan waarvoor ervaring belangrijk is dan laagopgeleiden.

De relatie tussen de waarde van iemands ervaring en leeftijd is ook interessant en verassend. Figuur 4.2 laat zien dat het percentage werknemers dat aangeeft dat ze nu gemakkelijker problemen kunnen oplossen dan toen ze nog onervaren waren in hun werk daalt met de leeftijd. De figuur laat echter ook zien dat bij ongeveer een kwart van de 55-plussers hun werkervaring hen niet in staat stelt om problemen op het werk gemakkelijker op te kunnen lossen. Dit wijst er op dat de competenties van deze mensen verouderd zijn geraakt, omdat de aard van het werk in de loop der jaren is veranderd. 


\section{Figuur 4.1}

Maakt ervaring het werk gemakkelijker? De mate waarin zich op het werk situaties voordoen die werknemers gemakkelijk zelf oplossen, terwijl zij vroeger, toen ze net werkzaam waren in hun functie, daar lang mee bezig zouden zijn geweest of om advies hadden moeten vragen, naar opleidingsniveau, 2010

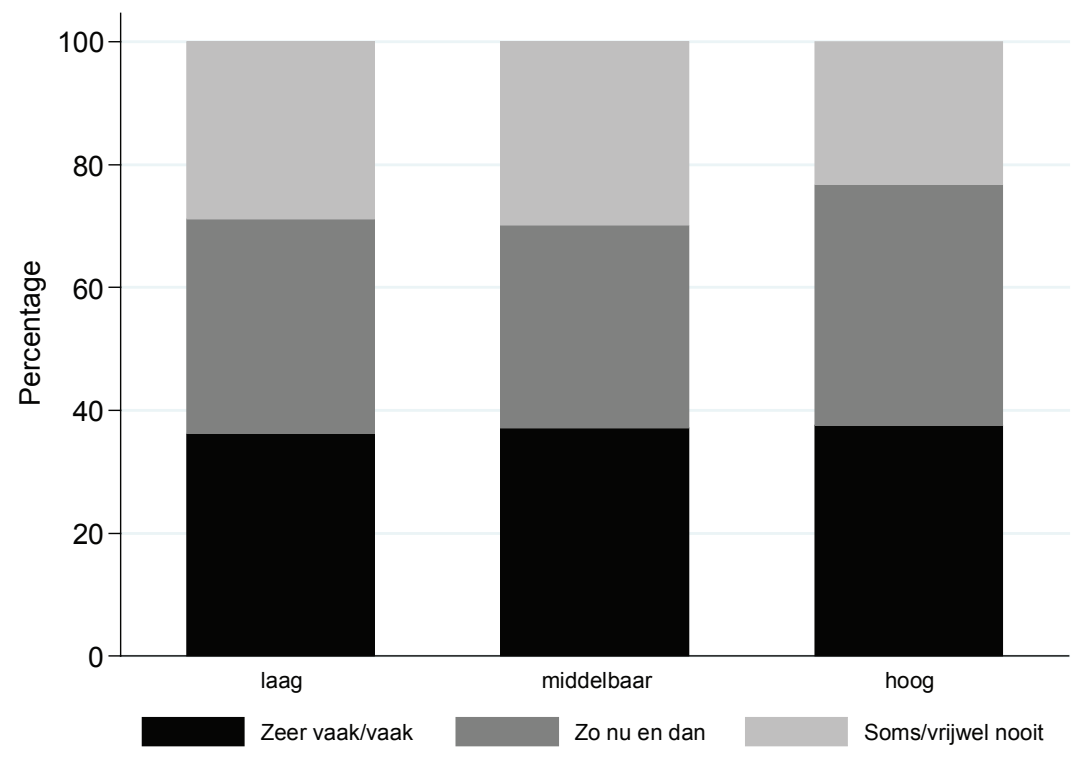

Figuur 4.2

Maakt ervaring het werk gemakkelijker? De mate waarin zich op het werk situaties voordoen die werknemers gemakkelijk zelf oplossen terwijl zij vroeger, toen ze net werkzaam waren in hun functie, daar lang mee bezig zouden zijn geweest of om advies hadden moeten vragen, naar leeftijd, 2010

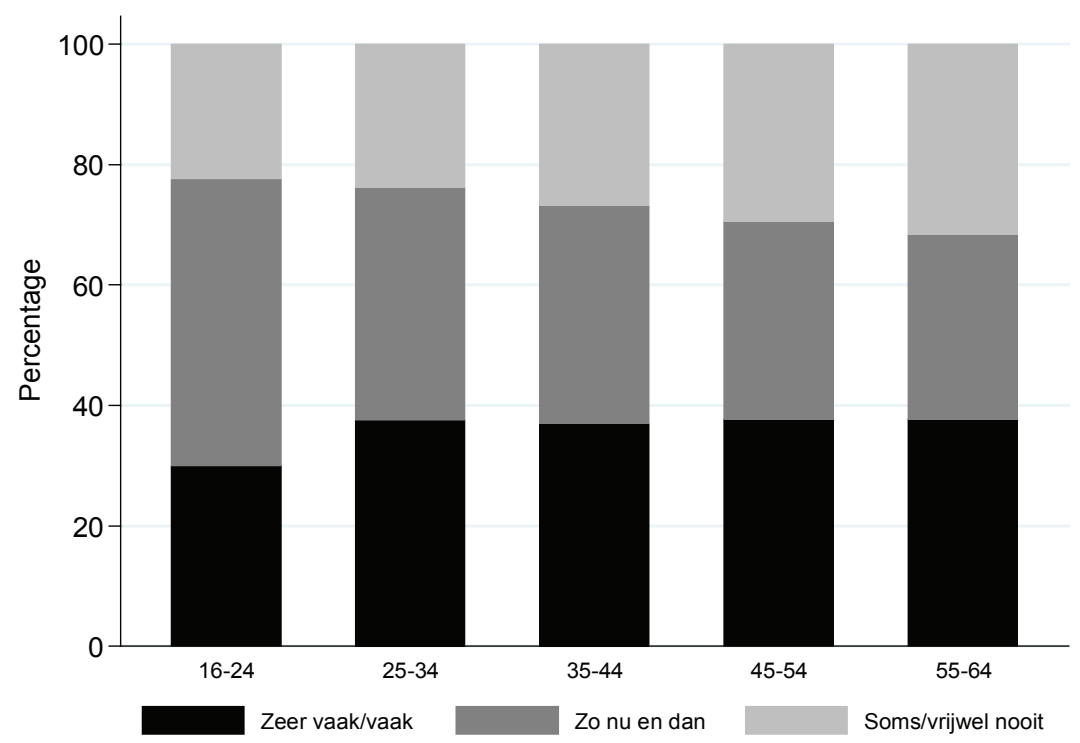




\section{Tekort aan ervaring?}

Op het werk kunnen zich situaties voordoen waar iemand lang mee bezig is, of waarvoor men advies moet vragen terwijl meer ervaren werknemers dergelijke problemen sneller oplossen. Dergelijke situaties duiden op een tekort aan ervaring. De mate waarin dergelijke situaties zich bij verschillende leeftijdsgroepen voordoen is afgebeeld in figuur 4.3. De figuur laat een duidelijk en significant leeftijdspatroon zien: naarmate de leeftijd stijgt, stijgt ook het percentage werknemers dat aangeeft dat er op het werk vrijwel nooit of hooguit soms sprake is van situaties waar men advies voor moet vragen terwijl anderen deze problemen gemakkelijker zelf oplossen. Anders gezegd: met het stijgen van de leeftijd daalt de kans dat iemand aangeeft dat hij of zij een tekort aan ervaring heeft. Er lijkt echter wel sprake te zijn van een afnemend rendement van ervaring, omdat de relatie met de leeftijd niet lineair is.

\section{Figuur 4.3}

Tekort aan ervaring? Mate waarin zich op het werk situaties voordoen waar iemand lang mee bezig is, of waarvoor men iemand anders om advies moet vragen, terwijl andere (meer ervaren) medewerkers deze problemen makkelijker zelf oplossen, 2010

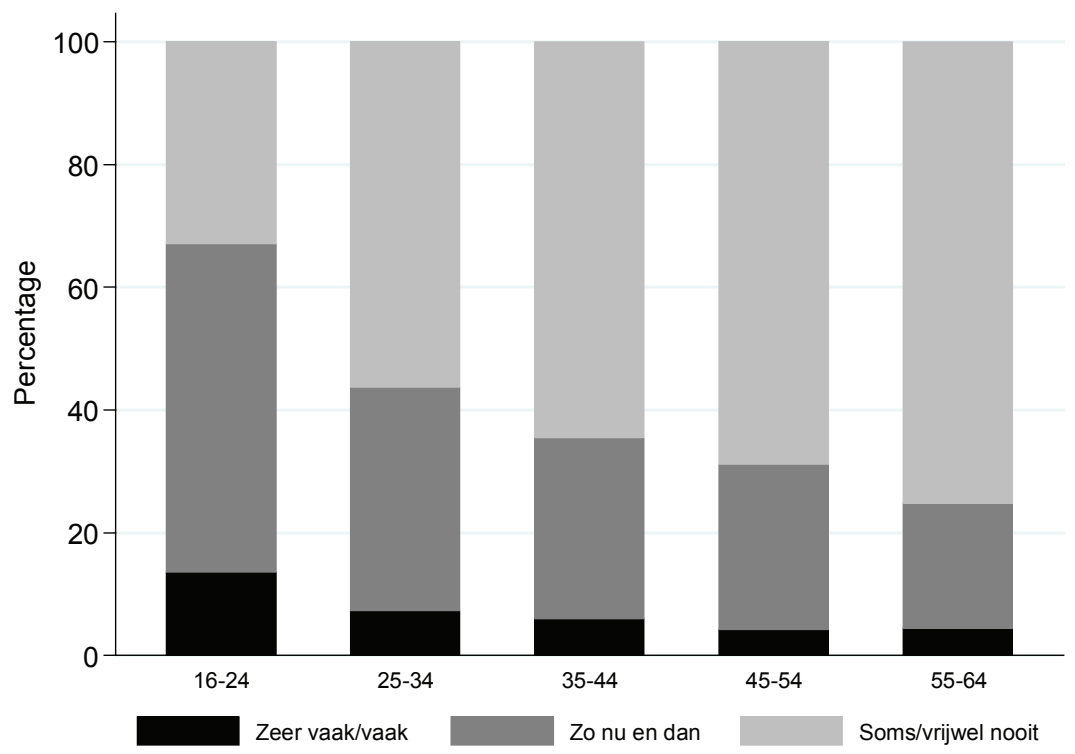

\subsection{Ervaring en kennisontwikkeling}

De standaard manier om ervaring te meten is om uit te gaan van het aantal jaren dat iemand heeft gewerkt. Bedrijfspecifieke ervaring wordt dan doorgaans gemeten als het aantal jaren dat iemand bij dezelfde werkgever heeft gewerkt. In de ROA Levenslang 
Leren Enquête 2010 is een poging gedaan om de arbeidsmarktervaring nauwkeuriger in beeld te brengen door uitgebreid in te gegaan op de arbeidsmarktloopbaan van de respondenten. Zo zijn er naast de informatie over het aantal jaren dat iemand reeds heeft gewerk $\mathrm{t}^{27}$ en het aantal jaren dat men al werkzaam is bij de huidige werkgever, ook retrospectieve gegevens over het aantal werkgevers waarvoor iemand heeft gewerkt, de mate waarin er sprake is geweest van substantiële veranderingen van werkzaamheden en het jaar waarin de laatste substantiële verandering in iemands werkzaamheden zich heeft voorgedaan. Ook is bekend hoe vaak iemand werkloos of arbeidsongeschikt is geweest. Daarnaast is aan de hand van de in de vorige paragraaf besproken variabelen een poging gedaan om de waarde van de opgedane ervaring te meten.

In tabel 4.I relateren wij de conventionele manier om ervaring te meten (het aantal jaren dat iemand heeft gewerkt) aan de mate waarin iemand op het werk kampt met een tekort aan ervaring, zoals die is weergegeven in figuur $4.3 .{ }^{28}$ Daarnaast wordt gekeken naar het effect van de arbeidsmarktloopbaan op iemands ervaringskennis. De waarde van iemands ervaring voor iemands probleemoplossend vermogen is positief gecorreleerd met het aantal jaren arbeidsmarktervaring. Hetzelfde geldt als wij uitgaan van de duur van dienstverband bij de huidige werkgever - de tenure (niet opgenomen in tabel). Het aantal jaren arbeidsmarktervaring is echter niet langer significant wanneer gecontroleerd wordt voor recente substantiële veranderingen van werkzaamheden.

Wie in de afgelopen twee jaar een substantiële verandering in werkzaamheden heeft meegemaakt rapporteert een significant lager ervaringsniveau vergeleken met iemand die een dergelijke verandering nooit heeft meegemaakt. ${ }^{29}$ Het effect duurt voort tot 5 jaar na de substantiële verandering van werkzaamheden. Hetzelfde geldt voor werkenden die in hun arbeidsloopbaan nog nooit een training hebben gevolgd en voor mensen die vaker werkloos zijn geweest. Het effect van substantiële veranderingen in iemands werkzaamheden die al langer dan vijf jaar geleden hebben plaatsgevonden is echter insignificant. Dit suggereert dat alleen recente veranderingen in werkzaamheden gepaard gaan met een geringer probleemoplossend vermogen, maar dat dit effect niet blijvend is. Dit laatste zou verklaard kunnen worden uit het feit dat werknemers veel op het werk leren, of dat zij hun geringere ervaring compenseren door middel van formele scholing. Later in dit hoofdstuk komen we hier op terug.

27. Het totaal aantal jaren dat iemand heeft gewerkt is gemeten in de DNB Household Survey en gekoppeld aan onze data.

28. De subjectieve ervaringsmaat zoals besproken in figuren 4.I en 4.2 correleert niet met de arbeidsmarktervaring.

29. Dit effect blijft significant wanneer gecontroleerd wordt voor iemands vermogen tot zelfregulatie, motivatie en risicoattitude. 
Tabel 4.1

Relatie tussen de arbeidsmarktgeschiedenis van werkenden en de mate waarin zij kampen met een tekort aan ervaring voor de uitoefening van hun werk, 2010

\begin{tabular}{|c|c|c|}
\hline & (1) & (2) \\
\hline \multicolumn{3}{|l|}{ Verklarende variabelen } \\
\hline Arbeidsmarktervaring in jaren (log) & $0,154^{*}$ & 0,130 \\
\hline Aantal werkgevers & & 0,006 \\
\hline Aantal substantiële veranderingen in werkzaamheden & & 0,039 \\
\hline \multicolumn{3}{|c|}{ Laatste substantiële verandering in werkzaamheden (ref: nooit) } \\
\hline afgelopen 2 jaar & & $-0,445^{* *}$ \\
\hline 2 tot 5 jaar geleden & & $-0,329^{*}$ \\
\hline langer dan 5 jaar geleden & & $-0,147$ \\
\hline Aantal keer werkloos of arbeidsongeschikt & & $-0,102^{* *}$ \\
\hline \multicolumn{3}{|l|}{ Controle variabelen ${ }^{2)}$} \\
\hline Nooit training gevolgd & $-0,191^{*}$ & $-0,200^{*}$ \\
\hline Vrouw & 0,076 & 0,078 \\
\hline \multicolumn{3}{|l|}{ Leeftijd (ref: $35-44$ jaar) } \\
\hline 16-24 jaar & $-0,360$ & $-0,520$ \\
\hline 25-34 jaar & 0,036 & 0,041 \\
\hline 45-54 jaar & 0,059 & 0,028 \\
\hline \multicolumn{3}{|l|}{ 55-64 jaar } \\
\hline Opleiding (ref: mbo) & 0,164 & 0,079 \\
\hline bo/vmbo & 0,108 & 0,098 \\
\hline havo/vwo & $0,347^{* *}$ & $0,314^{*}$ \\
\hline hbo & $-0,022$ & $-0,046$ \\
\hline wo & 0,152 & 0,148 \\
\hline Constante term & $0,847^{* * *}$ & $0,550^{*}$ \\
\hline Pseudo-R-kwadraat & 0,017 & 0,026 \\
\hline $\mathrm{N}$ & 599 & 599 \\
\hline \multicolumn{3}{|c|}{$\begin{array}{l}\text { 2) Overige controles: burgerlijke staat, aantal kinderen en dummy voor schoolverlaters in de } \\
\text { afgelopen } 2 \text { jaar. Daarnaast bevat het model } 4 \text { coëfficiënten voor de drempelwaardes van de } \\
\text { latente afhankelijke }\end{array}$} \\
\hline
\end{tabular}

Tabel 4.2 gaat in op de vraag hoe de arbeidsmarktloopbaan zich verhoudt tot het kennisniveau op het moment van enquête en de kennisontwikkeling in de afgelopen twee jaar. Daarnaast laat de tabel ook het verband tussen de arbeidsmarktloopbaan en het loon zien. De tabel laat zien dat het niveau van iemands kennis en vaardigheden positief gecorreleerd is met het aantal jaren arbeidsmarktervaring. De kennisontwikkeling is daarentegen niet gecorreleerd met de ervaringsjaren op de arbeidsmarkt.

Bij werkenden die te maken hebben met substantiële veranderingen in hun werkzaamheden is er sprake van een sterkere kennisontwikkeling. Daarbij gaat niet het aantal veranderingen dat er in iemands loopbaan heeft plaatsgevonden, maar alleen recente veranderingen (in de afgelopen 5 jaar) van werkzaamheden samen met een sterkere 
kennisontwikkeling. ${ }^{30}$ Dit betekent dat veranderingen in taken en werkzaamheden wel degelijk een impuls geven aan de kennisontwikkeling. Dit geldt overigens ook voor werkenden in de leeftijd 45-64 jaar. Dit betekent dat ook bij ouderen substantiële veranderingen in het werk kennisontwikkeling in de hand kunnen werken. De effecten van de ervaringsvariabelen op het loon zijn vergelijkbaar met de effecten van deze variabelen op het kennisniveau.

\section{Tabel 4.2}

Relatie tussen ervaring, kennisniveau en kennisontwikkeling (coëfficiënten uit OLS model), 20042010

\begin{tabular}{|c|c|c|c|}
\hline & $\begin{array}{c}\text { (1) } \\
\text { Kennisniveau }\end{array}$ & $\begin{array}{c}\text { (2) } \\
\text { Kennisontwikkeling }\end{array}$ & $\begin{array}{c}\text { (3) } \\
\text { Maandloon (log) }\end{array}$ \\
\hline \multicolumn{4}{|l|}{ Verklarende variabelen } \\
\hline Arbeidsmarktervaring in jaren (log) & $7,600^{* * *}$ & $-1,647$ & $0,165^{* * *}$ \\
\hline Aantal werkgevers & $-0,185$ & 0,015 & $-0,020$ \\
\hline Aantal substantiële veranderingen in werkzaamheden & $0,934^{*}$ & $-0,323$ & $0,034^{* *}$ \\
\hline \multicolumn{4}{|c|}{ Laatste substantiële verandering in werkzaamheden (ref: nooit) } \\
\hline afgelopen 2 jaar & $-5,812$ & $6,039 * * *$ & $-0,082$ \\
\hline 2 tot 5 jaar geleden & $-1,779$ & $4,871^{* *}$ & $-0,049$ \\
\hline langer dan 5 jaar geleden & 1,434 & 1,282 & $-0,053$ \\
\hline Aantal keer werkloos of arbeidsongeschikt & 0,737 & $-0,069$ & $-0,014$ \\
\hline \multicolumn{4}{|l|}{ Controle variabelen") } \\
\hline Nooit training gevolgd & $-8,396^{* * *}$ & $-3,345^{* *}$ & $-0,159^{* *}$ \\
\hline Vrouw & 2,543 & 0,298 & $-0,331^{* * *}$ \\
\hline \multicolumn{4}{|l|}{ Leeftijd (ref: $35-44$ jaar) } \\
\hline 16-24 jaar & $20,930^{* *}$ & 7,302 & $-0,419^{*}$ \\
\hline 25-34 jaar & $6,254^{*}$ & 0,299 & $-0,051$ \\
\hline 45-54 jaar & $-2,665$ & 0,378 & $-0,051$ \\
\hline 55-64 jaar & $-3,906$ & $-2,004$ & 0,043 \\
\hline \multicolumn{4}{|l|}{ Opleiding (ref: mbo) } \\
\hline vmbo \& bo & $-1,427$ & 1,131 & $-0,162^{*}$ \\
\hline havo \& vwo & 1,748 & $-0,774$ & 0,147 \\
\hline hbo & $5,991^{* *}$ & $-0,381$ & $0,195^{* *}$ \\
\hline wo & $7,796^{* *}$ & $-0,388$ & $0,376^{* * *}$ \\
\hline Constante term & $53,744^{* * *}$ & $7,262^{*}$ & $9,096^{* * *}$ \\
\hline Adjusted-R-kwadraat & 0,067 & 0,082 & 0,361 \\
\hline $\mathrm{N}$ & 599 & 599 & 499 \\
\hline $\begin{array}{l}{ }^{*} \mathrm{p}<0.10^{* *} \mathrm{p}<0.05^{* * *} \mathrm{p}<0.01 \\
\text { 1) Overige controles: burgerlijke staat, aar } \\
\text { afgelopen } 2 \text { jaar. Model } 3 \text { controleert o }\end{array}$ & en en & $\begin{array}{l}\text { voor schoolv } \\
\text { rkte uren. }\end{array}$ & ers in de \\
\hline
\end{tabular}

De tabel laat ook zien dat zowel het niveau van iemands kennis en vaardigheden als iemands kennisontwikkeling sterk samenhangen met de gedane investeringen in

30. Dit effect blijft significant wanneer gecontroleerd wordt voor iemands vermogen tot zelfregulatie, motivatie en risicoattitude. 
iemands menselijk kapitaal: wie nooit een cursus of training heeft gevolgd heeft een lager kennisniveau en leert ook minder bij op het werk.

Het is ten slotte interessant om te noteren dat hoewel hoogopgeleiden een hoger kennisniveau rapporteren in vergelijking met lager opgeleiden, hun kennisontwikkeling niet anders is. De mate waarin men van jaar op jaar bijleert is dus, in relatieve zin, onafhankelijk van het opleidingsniveau.

\subsection{Arbeidsmarktgeschiedenis en leren op het werk}

Paragraaf 4.2 heeft laten zien dat er een verband is tussen recente substantiële veranderingen van werkzaamheden en de opgebouwde ervaring en kennisontwikkeling. Dit roept de vraag op welke mechanismen hier achter zitten. Gaan substantiële veranderingen van werkzaamheden gepaard met meer formeel leren, meer informeel leren of met allebei?

Tabel 4.3 laat zien dat substantiële veranderingen van werkzaamheden geen significante relaties vertonen met de trainingsparticipatie, maar wel met informeel leren (zowel het aantal veranderingen als recente veranderingen). Dit zou het positieve effect van veranderingen in werkzaamheden op de kennisontwikkeling kunnen verklaren. Als men controleert voor persoonlijkheidskenmerken als zelfregulatie, intrinsieke motivatie en risicoattitude (niet opgenomen in tabel), blijft het effect van substantiële veranderingen in werkzaamheden op informeel leren significant en nagenoeg even sterk.

Werkenden die vaker werkloos of arbeidsongeschikt zijn geweest blijken de afgelopen twee jaar minder vaak een training te hebben gevolgd.

\section{Kans op benutting voucher}

Ook hebben we gekeken of de kans op het benutten van de scholingsvoucher, die uitgebreid aan bod is gekomen in hoofdstuk 3, gerelateerd is aan de arbeidsmarktgeschiedenis van werkenden. Tabel 4.4 laat zien dat het aantal werkgevers dat iemand heeft gehad positief samenhangt met de waarschijnlijkheid dat men de voucher gaat benutten. Dit geldt ook voor recente substantiële veranderingen van werkzaamheden: wie in de afgelopen twee jaar dergelijke veranderingen van werkzaamheden heeft meegemaakt heeft ook een grotere kans om de voucher te gaan gebruiken. Dit geldt ook voor veranderingen 2 tot 5 jaar geleden, maar dit effect is minder significant. Dit hogere gebruik blijft significant wanneer gecontroleerd wordt voor iemands motivatie, zelfregulatie en risicoattitude.

Degenen die vaak van werkgever zijn veranderd hebben minder vaak de voorkeur om de voucher te gebruiken voor een zeer specifieke cursus. Met andere woorden: de werkenden die vaak mobiel zijn op de arbeidsmarkt hebben de bereidheid om zich 
te trainen, maar geen specifieke voorkeur voor een bepaalde training. Ook op dit punt lijken zij zich dus flexibeler op te stellen. ${ }^{3 \mathrm{I}}$ Hoe vaker men substantiële veranderingen van werkzaamheden heeft meegemaakt, hoe specifieker het onderwerp van de training.

Tabel 4.3

Relatie tussen arbeidsmarktveranderingen en training en informeel leren (coëfficiënten uit probit en OLS model), werkenden, 2010

\begin{tabular}{|c|c|c|}
\hline & $\begin{array}{c}(1) \\
\text { Training }\end{array}$ & $\begin{array}{c}\text { (2) } \\
\text { Informeel leren }{ }^{2)}\end{array}$ \\
\hline \multicolumn{3}{|l|}{ Verklarende variabelen } \\
\hline Arbeidsmarktervaring in jaren (log) & 0,097 & 1,995 \\
\hline Aantal werkgevers & $-0,010$ & $-0,217$ \\
\hline Aantal substantiële veranderingen in werkzaamheden & 0,042 & $1,006^{*}$ \\
\hline \multicolumn{3}{|c|}{ Laatste substantiële verandering in werkzaamheden (ref: nooit) } \\
\hline afgelopen 2 jaar & 0,110 & $9,264^{* *}$ \\
\hline 2 tot 5 jaar geleden & 0,094 & 3,606 \\
\hline langer dan 5 jaar geleden & 0,053 & 2,140 \\
\hline Aantal keer werkloos of arbeidsongeschikt & $-0,114^{* *}$ & $-1,456$ \\
\hline \multicolumn{3}{|l|}{ Controle variabelen ${ }^{3)}$} \\
\hline Vrouw & 0,048 & $-0,064$ \\
\hline \multicolumn{3}{|l|}{ Leeftijd (ref: 35-44 jaar) } \\
\hline 16-24 jaar & $-0,109$ & $24,506^{* * *}$ \\
\hline 25-34 jaar & $-0,229$ & 5,303 \\
\hline 45-54 jaar & $-0,087$ & $-1,614$ \\
\hline 55-64 jaar & $-0,276$ & $-4,729$ \\
\hline \multicolumn{3}{|l|}{ Opleiding (ref: mbo) } \\
\hline bo/vmbo & $-0,087$ & $-1,956$ \\
\hline havo/vwo & $-0,251$ & $-2,762$ \\
\hline hbo & $0,307^{* *}$ & 4,562 \\
\hline wo & $0,331^{*}$ & $8,737^{* *}$ \\
\hline Constante term & $-0,002$ & $16,291^{* *}$ \\
\hline Pseudo-R-kwadraat & 0,054 & \\
\hline Adjusted-R-kwadraat & & 0,058 \\
\hline $\mathrm{N}$ & 641 & 599 \\
\hline \multicolumn{3}{|c|}{$\begin{array}{l}{ }^{*} p<0.10^{* *} p<0.05 * * * p<0.01 \\
\text { 1) Probit model } \\
\text { 2) OLS model } \\
\text { 3) Overige controles: burgerlijke staat, aantal kinderen en dummy voor schoolverlaters in de } \\
\text { afgelopen } 2 \text { jaar. }\end{array}$} \\
\hline
\end{tabular}

3I. De surveydata bevatten geen gegevens over het soort contract, maar uit analyses op basis van het OSA-Arbeidsaanbodpanel blijkt dat werknemers met een tijdelijk contract (al dan niet met uitzicht op vast) voor een groter aantal werkgevers hebben gewerkt (ook nadat gecontroleerd is voor geslacht, leeftijd en opleidingsniveau). Het aantal werkgevers van werknemers met een flexibel contract verschilt echter niet van dat van werknemers met een vaste aanstelling. 
Tabel 4.4

Relatie tussen arbeidsmarktveranderingen en het gebruik van een trainingsvoucher en de voorkeur voor een bepaalde training (coëfficiënten uit ordered probit model), werkenden, 2010

\begin{tabular}{|c|c|c|}
\hline & $\begin{array}{c}\text { (1) } \\
\text { Kans gebruik } \\
\text { voucher }\end{array}$ & $\begin{array}{c}\text { (2) } \\
\text { Voorkeur specifiek } \\
\text { onderwerp }\end{array}$ \\
\hline \multicolumn{3}{|l|}{ Verklarende variabelen } \\
\hline Arbeidsmarktervaring in jaren (log) & 0,074 & 0,113 \\
\hline Aantal werkgevers & $0,090^{* * *}$ & $-0,050^{* *}$ \\
\hline Aantal substantiële veranderingen in werkzaamheden & $-0,023$ & $0,051^{* *}$ \\
\hline \multicolumn{3}{|c|}{ Laatste substantiële verandering in werkzaamheden (ref: nooit) } \\
\hline afgelopen 2 jaar & $0,588^{* * *}$ & $-0,023$ \\
\hline 2 tot 5 jaar geleden & $0,334^{*}$ & $-0,159$ \\
\hline langer dan 5 jaar geleden & 0,116 & $-0,074$ \\
\hline Aantal keer werkloos of arbeidsongeschikt & $-0,049$ & 0,017 \\
\hline \multicolumn{3}{|l|}{ Controle variabelen ${ }^{1)}$} \\
\hline Vrouw & $0,195^{* *}$ & $-0,014$ \\
\hline \multicolumn{3}{|l|}{ Leeftijd (ref: $35-44$ jaar) } \\
\hline 16-24 jaar & $-0,134$ & 0,031 \\
\hline 25-34 jaar & 0,277 & 0,010 \\
\hline 45-54 jaar & $-0,167$ & $-0,107$ \\
\hline $55-64$ jaar & $-0,427^{* * *}$ & $-0,235$ \\
\hline \multicolumn{3}{|l|}{ Opleiding (ref: mbo) } \\
\hline bo/vmbo & $-0,460^{* * *}$ & 0,046 \\
\hline havo/vwo & $-0,320^{*}$ & $-0,198$ \\
\hline hbo & 0,027 & 0,185 \\
\hline wo & 0,196 & 0,057 \\
\hline Pseudo-R-kwadraat & 0,061 & 0,019 \\
\hline $\mathrm{N}$ & 568 & 568 \\
\hline
\end{tabular}

${ }^{*} \mathrm{p}<0.10 * * \mathrm{p}<0.05 * * * \mathrm{p}<0.01$

1) Overige controles: burgerlijke staat, aantal kinderen en dummy voor schoolverlaters in de afgelopen 2 jaar. Daarnaast bevat het model 4 coëfficiënten voor de drempelwaardes van de latente afhankelijke variabele.

\subsection{Leren, employability en mobiliteit}

Omdat veranderingen op de arbeidsmarkt (van werkgever of van werkzaamheden) een verband hebben met de deelname aan scholing, informeel leren en de opbouw van menselijk kapitaal (de kennisontwikkeling), kan men zich de vraag stellen in welke mate deze veranderingen de employability en de verwachte baanmobiliteit van werknemers bepalen. 


\section{Employability en verlies van baan}

De ROA Levenslang Leren Enquête bevat informatie over de employability van werkenden en de kans op baanverlies. Employability wordt afgeleid uit de enquêtevraag: "als u op zoek zou gaan naar een andere baan wat is de kans dat u een baan zou vinden op vergelijkbaar niveau als uw huidige baan?”. De kans op baanverlies wordt afgeleid uit de vraag "hoe groot is de kans dat u inde komende s jaar uw baan verliest?". Op beide vragen kunnen respondenten een antwoord geven op een schaal van I "zeer onwaarschijnlijk" tot 5 "zeer waarschijnlijk".

Figuur 4.4 geeft voor de jaren 2004, 2007 en 2010 de indicatoren weer voor employability en de kans op baanverlies. Gemiddeld genomen wordt de employability in 2010 significant lager ingeschat dan in 2007 en ligt het weer op een vergelijkbaar niveau als in 2004. De kans op baanverlies wordt in 2010 weer significant hoger ingeschat dan in 2007.

\section{Figuur 4.4}

Waarschijnlijkheid van vinden van baan op zelfde niveau en risico op verlies van baan in komende 5 jaar, 2004-2010

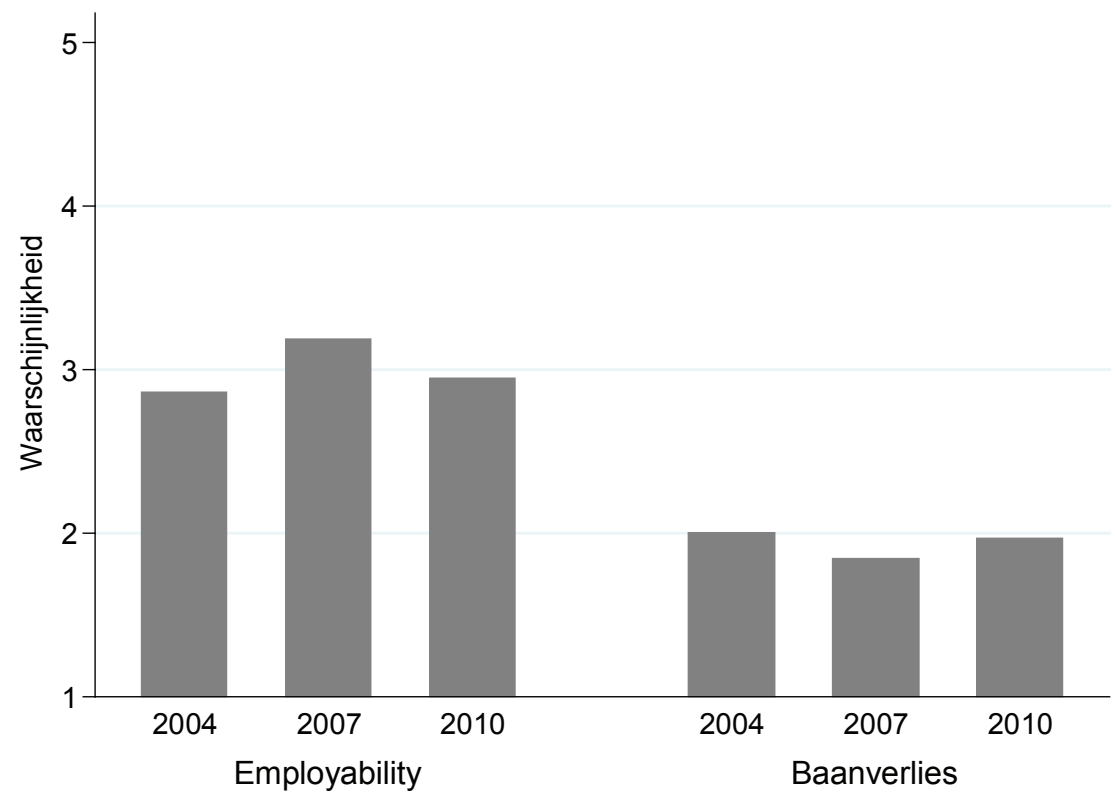

Tabel 4.5 geeft aan welke kenmerken samenhangen met een grotere employability. De tabel laat zien dat er weinig samenhang is tussen het leren op het werk (formeel of informeel), de arbeidsmarktgeschiedenis en de door de werkenden gepercipieerde 
employability. Persoonlijkheidskenmerken hangen wel positief samen met de eigen inschatting van iemands employability. Zo blijkt dat werkenden met een hogere mate van zelfregulatie of een sterkere risicoattitude hun employability hoger inschatten.

\section{Tabel 4.5}

Determinanten van employability (coëfficiënten uit ordered probit model), 2010

\begin{tabular}{|c|c|c|c|}
\hline & (1) & $(2)$ & (3) \\
\hline \multicolumn{4}{|l|}{ Verklarende variabelen } \\
\hline Training in afgelopen 2 jaar & 0,036 & 0,043 & $-0,010$ \\
\hline Informeel leren & $-0,001$ & $-0,001$ & $-0,002$ \\
\hline Arbeidsmarktervaring in jaren (log) & & 0,020 & 0,024 \\
\hline Aantal werkgevers & & 0,022 & 0,001 \\
\hline Aantal substantiële veranderingen in werkzaamheden & & 0,024 & 0,019 \\
\hline \multicolumn{4}{|c|}{ Laatste substantiële verandering in werkzaamheden (ref: nooit) } \\
\hline afgelopen 2 jaar & & 0,074 & 0,010 \\
\hline 2 tot 5 jaar geleden & & $-0,268$ & $-0,368^{* *}$ \\
\hline langer dan 5 jaar geleden & & $-0,047$ & $-0,102$ \\
\hline Aantal keer werkloos of arbeidsongeschikt & & 0,024 & 0,042 \\
\hline Zelfregulatie & & & $0,156^{* * *}$ \\
\hline Intrinsieke motivatie & & & 0,070 \\
\hline Risicoattitude & & & $0,238^{* * *}$ \\
\hline \multicolumn{4}{|l|}{ Controle variabelen"1) } \\
\hline Vrouw & $-0,186^{*}$ & $-0,183^{*}$ & $-0,167$ \\
\hline \multicolumn{4}{|l|}{ Leeftijd (ref: 35-44 jaar) } \\
\hline 16-24 jaar & $-0,020$ & 0,091 & 0,009 \\
\hline 25-34 jaar & 0,085 & 0,158 & 0,169 \\
\hline 45-54 jaar & $-0,410^{* * *}$ & $-0,451^{* * *}$ & $-0,489^{* * *}$ \\
\hline 55-64 jaar & $-1,027^{* * *}$ & $-1,063^{* * *}$ & $-1,184^{* * *}$ \\
\hline \multicolumn{4}{|l|}{ Opleiding (ref: mbo) } \\
\hline bo/vmbo & $-0,132$ & $-0,136$ & $-0,153$ \\
\hline havo/vwo & 0,106 & 0,070 & 0,097 \\
\hline hbo & 0,048 & 0,032 & $-0,019$ \\
\hline wo & $0,504^{* * *}$ & $0,499^{* * *}$ & $0,369^{* *}$ \\
\hline Constante term & $1,001^{* * *}$ & $1,172^{* * *}$ & $0,923^{* * *}$ \\
\hline Pseudo-R-kwadraat & 0,070 & 0,075 & 0,099 \\
\hline $\mathrm{N}$ & 595 & 595 & 593 \\
\hline
\end{tabular}

${ }^{*} \mathrm{p}<0.10 * * \mathrm{p}<0.05 * * * \mathrm{p}<0.01$

1) Overige controles: sector van activiteit, burgerlijke staat, aantal kinderen en dummy voor schoolverlaters in de afgelopen 2 jaar. Daarnaast bevat het model 4 coëfficiënten voor de drempelwaardes van de latente afhankelijke variabele.

Voor werkenden in de leeftijdsgroep 45-54 is de employability geringer dan voor de leeftijdgroep 35-44 jaar. Voor werkenden in de leeftijdgroep 55-64 is de employability nog slechter. Aan deze leeftijdsverschillen verandert nagenoeg niets wanneer we controleren voor persoonlijkheidkenmerken en iemands arbeidsmarktgeschiedenis. 
De leeftijdsverschillen zijn ook niet verschillend voor werkenden die in de afgelopen twee jaar hebben deelgenomen aan scholing vergeleken met werkenden die dit niet hebben gedaan (niet gerapporteerd in tabel). De verschillen in employability tussen de hoogst opgeleiden en andere werknemers blijken wel kleiner te worden wanneer rekening wordt gehouden met verschillen in persoonlijkheid.

Tabel 4.6 laat de resultaten zien van een vergelijkbare analyse voor de kans op baanverlies in de komende 5 jaar. Trainingsparticipatie blijkt negatief gecorreleerd met de kans op baanverlies in de komende 5 jaar. Iemands arbeidsmarktervaring is ook gecorreleerd met de kans op baanverlies: werkenden geven vaker aan te denken dat ze hun baan kwijtraken wanneer zij in het verleden vaker werkloos of arbeidsongeschikt zijn geweest. Ook is het aantal werkgevers waarvoor men gewerkt heeft positief gecorreleerd met de kans op baanverlies.

Een hogere mate van zelfregulatie gaat gepaard met een kleinere kans om de baan waarin men werkzaam is kwijt te raken. Het is opmerkelijk dat de kans op baanverlies niet verschillend wordt ingeschat door werknemers met een verschillend opleidingsniveau. Ook zijn er op dit punt geen verschillen tussen leeftijdsgroepen. Wanneer er tussen jongeren en ouderen geen verschil is in de kans op baanverlies, terwijl er wel een significant verschil is in de kans om bij een ander bedrijf te kunnen gaan werken (de 'employability') dan zou dit kunnen betekenen dat oudere werknemers weliswaar goed kunnen meekomen in hun baan en niet meer of minder moeite hebben met het bijbenen van veranderingen op het werk dan jongere werknemers maar wel meer moeilijkheden krijgen wanneer ze op zoek moeten naar een andere baan op een vergelijkbaar niveau. Vanuit beleidsperspectief pleit dit er voor om oudere werknemers vooral inzetbaar te houden in hun huidige baan, en te bewerkstelligen dat ze eerder in hun loopbaan door functieroulatie en/of verandering van het takenpakket binnen hun functie bredere kennis en vaardigheden opbouwen.

\section{Werk bij ander bedrijf}

Op een dynamische arbeidsmarkt willen werknemers wel eens ander werk gaan doen of voor een andere werkgever gaan werken. In de 2007 en 20 Io peilingen van de $R O A$ Levenslang Leren Enquête wordt de vraag gesteld in welke mate (op een schaal van I "zeker niet" tot 5 "erg graag") respondenten over 5 jaar bij een ander bedrijf zouden willen werken. Vervolgens wordt de vraag gesteld of zij ook verwachten over 5 jaar daadwerkelijk bij een ander bedrijf te zullen werken (I "zeer onwaarschijnlijk", 5 "zeer waarschijnlijk").

Figuur 4.5 geeft een overzicht van de antwoorden op deze twee vragen. Het laat zien dat de wens om binnen 5 jaar voor een ander bedrijf te werken in 2010 lager is dan in 2007. Zo ook de kans dat men denkt dat dit daadwerkelijk het geval zal zijn. Beide verschillen zijn statistisch significant. 
Tabel 4.6

Determinanten van kans op baanverlies (coëfficiënten uit ordered probit model), 2004-2010

\begin{tabular}{|c|c|c|c|}
\hline & (1) & (2) & (3) \\
\hline \multicolumn{4}{|l|}{ Verklarende variabelen } \\
\hline Training in afgelopen 2 jaar & $-0,252^{* *}$ & $-0,219^{* *}$ & $-0,178^{*}$ \\
\hline Informeel leren & 0,000 & 0,001 & 0,001 \\
\hline Arbeidsmarktervaring in jaren (log) & & $-0,104$ & $-0,072$ \\
\hline Aantal werkgevers & & $0,045^{*}$ & $0,046^{*}$ \\
\hline Aantal substantiële veranderingen in werkzaamheden & & $-0,025$ & $-0,026$ \\
\hline \multicolumn{4}{|l|}{ Laatste substantiële verandering in werkzaamheden (ref: nooit) } \\
\hline afgelopen 2 jaar & & 0,083 & 0,044 \\
\hline 2 tot 5 jaar geleden & & $0,321^{*}$ & 0,299 \\
\hline langer dan 5 jaar geleden & & $-0,018$ & $-0,048$ \\
\hline Aantal keer werkloos of arbeidsongeschikt & & $0,094^{* *}$ & $0,086^{* *}$ \\
\hline Zelfregulatie & & & $-0,215^{* * *}$ \\
\hline Intrinsieke motivatie & & & $-0,042$ \\
\hline Risicoattitude & & & 0,082 \\
\hline \multicolumn{4}{|l|}{ Controle variabelen") } \\
\hline Vrouw & 0,147 & 0,135 & 0,163 \\
\hline \multicolumn{4}{|l|}{ Leeftijd (ref: 35-44 jaar) } \\
\hline 16-24 jaar & $-0,141$ & $-0,184$ & $-0,160$ \\
\hline 25-34 jaar & $-0,000$ & $-0,023$ & 0,024 \\
\hline 45-54 jaar & $-0,023$ & 0,059 & 0,085 \\
\hline 55-64 jaar & $-0,193$ & $-0,013$ & 0,042 \\
\hline \multicolumn{4}{|l|}{ Opleiding (ref: mbo) } \\
\hline bo/vmbo & $-0,072$ & $-0,103$ & $-0,079$ \\
\hline havo/vwo & $-0,038$ & 0,011 & $-0,003$ \\
\hline hbo & $-0,000$ & 0,005 & 0,025 \\
\hline wo & 0,091 & 0,088 & 0,156 \\
\hline Constante term & $1,306^{* * *}$ & $1,383^{* * *}$ & $1,556^{* * *}$ \\
\hline Pseudo-R-kwadraat & 0,028 & 0,042 & 0,056 \\
\hline N & 539 & 539 & 537 \\
\hline
\end{tabular}

${ }^{*} \mathrm{p}<0.10 * * \mathrm{p}<0.05 * * * \mathrm{p}<0.01$

1) Overige controles: sector van activiteit, burgerlijke staat, aantal kinderen en dummy voor schoolverlaters in de afgelopen 2 jaar. Daarnaast bevat het model 4 coëfficiënten voor de drempelwaardes van de latente afhankelijke variabele. 


\section{Figuur 4.5}

Wens om over 5 jaar bij ander bedrijf te willen werkenen de verwachte kans dat dit gebeurt, 20072010

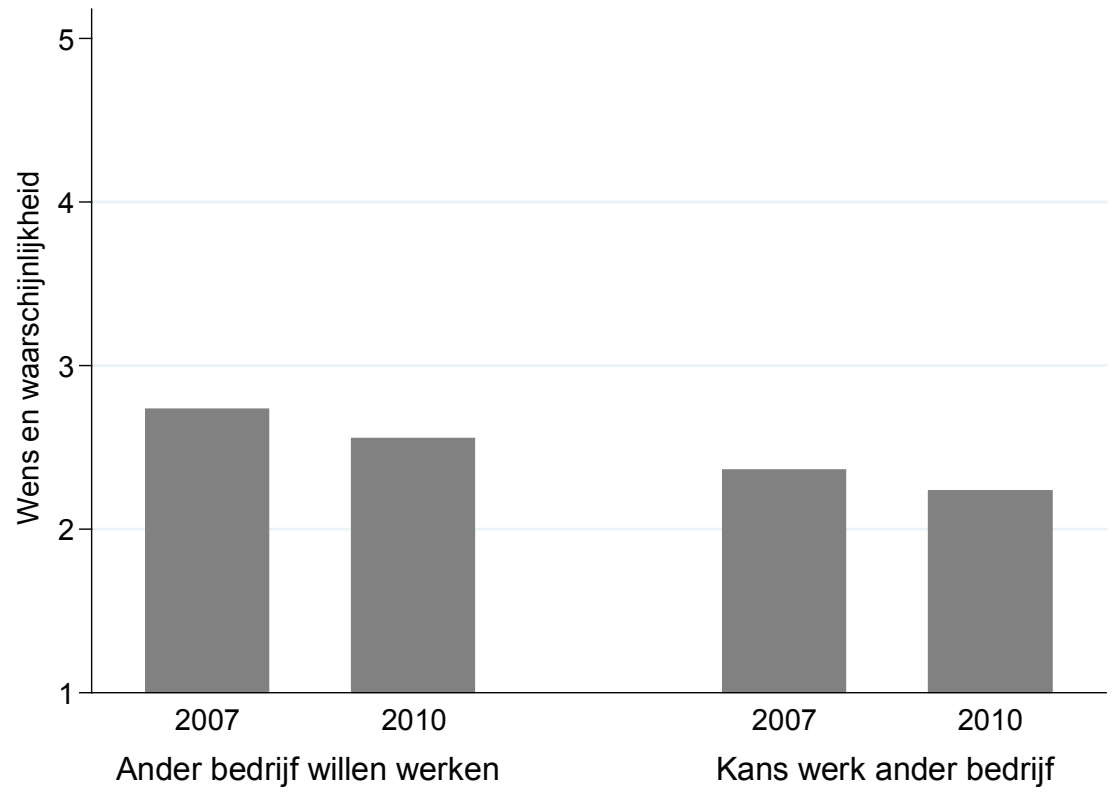

De kenmerken van werknemers met een wens om voor een ander bedrijf te werken worden onderzocht in tabel 4.7. Daaruit blijkt dat het volgen van een training en de mate waarin iemand op het werk informeel leert (althans wanneer gecontroleerd wordt voor de ervaringsvariabelen) negatief samenhangen met de wens om voor een ander bedrijf te werken. Dit kan er op wijzen dat dergelijke investeringen in iemands menselijk kapitaal vooral bedrijfsspecifiek zijn, dan wel dat werkenden die een training volgen een bepaalde mate van commitment voelen voor de werkgever waar ze werkzaam zijn.

Werkenden die in het verleden bij meer werkgevers hebben gewerkt en werkenden die te maken hebben gehad met substantiële veranderingen in hun werkzaamheden, hebben vaker de wens om over 5 jaar bij een andere werkgever te werken. Bij substantiële veranderingen van werkzaamheden is deze relatie echter niet langer significant wanneer gecontroleerd wordt voor iemands persoonlijkheid. Iemands intrinsieke motivatie en risicoattitude blijken sterk positief gecorreleerd te zijn met de wens om binnen 5 jaar voor een andere werkgever te werken. Vrouwen en oudere werknemers zijn daarentegen meer honkvast. 
Tabel 4.7

Determinanten van de kans dat iemand over 5 jaar bij een ander bedrijf zou willen werken (coëfficiënten uit ordered probit model), 2010

\begin{tabular}{|c|c|c|c|}
\hline & (1) & (2) & (3) \\
\hline \multicolumn{4}{|l|}{ Verklarende variabelen } \\
\hline Training in afgelopen 2 jaar & $-0,258^{* * *}$ & $-0,258^{* * *}$ & $-0,318^{* * *}$ \\
\hline Informeel leren & $-0,003$ & $-0,003^{*}$ & $-0,004^{* *}$ \\
\hline Arbeidsmarktervaring in jaren (log) & & $-0,160^{*}$ & $-0,142$ \\
\hline Aantal werkgevers & & $0,071^{* * *}$ & $0,055^{* *}$ \\
\hline Aantal substantiële veranderingen in werkzaamheden & & 0,035 & 0,038 \\
\hline \multicolumn{4}{|c|}{ Laatste substantiële verandering in werkzaamheden (ref: nooit) } \\
\hline afgelopen 2 jaar & & 0,156 & 0,036 \\
\hline 2 tot 5 jaar geleden & & 0,131 & 0,007 \\
\hline langer dan 5 jaar geleden & & 0,144 & 0,079 \\
\hline Aantal keer werkloos of arbeidsongeschikt & & 0,025 & 0,031 \\
\hline Zelfregulatie & & & $-0,002$ \\
\hline Intrinsieke motivatie & & & $0,272^{* * *}$ \\
\hline Risicoattitude & & & $0,124^{* *}$ \\
\hline \multicolumn{4}{|l|}{ Controle variabelen"1) } \\
\hline Vrouw & $-0,223^{* *}$ & $-0,214^{*}$ & $-0,243^{* *}$ \\
\hline \multicolumn{4}{|l|}{ Leeftijd (ref: $35-44$ jaar) } \\
\hline 16-24 jaar & $-0,208$ & $-0,191$ & $-0,202$ \\
\hline 25-34 jaar & $-0,136$ & $-0,111$ & $-0,150$ \\
\hline 45-54 jaar & $-0,246^{* *}$ & $-0,202$ & $-0,202$ \\
\hline 55-64 jaar & $-1,004^{* * *}$ & $-0,939^{* * *}$ & $-1,004^{* * *}$ \\
\hline \multicolumn{4}{|l|}{ Opleiding (ref: mbo) } \\
\hline bo/vmbo & $-0,248^{*}$ & $-0,272^{*}$ & $-0,191$ \\
\hline havo/vwo & $-0,016$ & $-0,020$ & 0,025 \\
\hline hbo & 0,131 & 0,077 & 0,053 \\
\hline wo & $0,329^{*}$ & 0,274 & 0,261 \\
\hline Constante term & $0,725^{* * *}$ & $0,759^{* *}$ & $0,705^{* *}$ \\
\hline Pseudo-R-kwadraat & 0,065 & 0,082 & 0,097 \\
\hline N & 539 & 539 & 537 \\
\hline
\end{tabular}

${ }^{*} p<0.10 * * 0<0.05 * * * 00.01$

1) Overige controles: sector van activiteit, burgerlijke staat, aantal kinderen en dummy voor schoolverlaters in de afgelopen 2 jaar. Daarnaast bevat het model 4 coëfficiënten voor de drempelwaardes van de latente afhankelijke variabele.

Tabel 4.8 laat zien dat de mate waarin men denkt over 5 jaar daadwerkelijk voor een andere werkgever te zullen werken vooral positief samenhangt met het aantal werkgevers dat men eerder heeft gehad. Andere aspecten van iemands arbeidsmarktgeschiedenis lijken er daarentegen weinig toe te doen. Daarnaast spelen iemands intrinsieke motivatie en risicoattitude een significante positieve rol.

Uit de laatste kolom van tabel 4.8 blijkt dat hoe sterker de wens is om bij een ander bedrijf te gaan werken, hoe groter men de kans inschat dat dit ook gaat gebeuren. 
Omdat iemands intrinsieke motivatie en het aantal werkgevers waarvoor men heeft gewerkt belangrijke determinanten zijn van de wens om bij een ander bedrijf te gaan werken, is het niet verwonderlijk dat deze twee variabelen in kolom 4 niet langer significant zijn.

\section{Tabel 4.8}

Determinanten van de kans om over 5 jaar bij een ander bedrijf te werken (coëfficiënten uit ordered probit model), 2010

\begin{tabular}{|c|c|c|c|c|}
\hline & (1) & $(2)$ & (3) & (4) \\
\hline \multicolumn{5}{|l|}{ Verklarende variabelen } \\
\hline Training in afgelopen 2 jaar & $-0,129$ & $-0,123$ & $-0,156$ & 0,047 \\
\hline Informeel leren & $-0,002$ & $-0,002$ & $-0,003$ & $-0,001$ \\
\hline Arbeidsmarktervaring in jaren (log) & & $-0,129$ & $-0,100$ & $-0,005$ \\
\hline Aantal werkgevers & & $0,061^{* *}$ & $0,044^{*}$ & 0,022 \\
\hline Aantal substantiële veranderingen in werkzaamheden & & 0,037 & 0,037 & 0,020 \\
\hline \multicolumn{5}{|c|}{ Laatste substantiële verandering in werkzaamheden (ref: nooit) } \\
\hline afgelopen 2 jaar & & 0,089 & $-0,021$ & $-0,026$ \\
\hline 2 tot 5 jaar geleden & & 0,108 & $-0,018$ & 0,001 \\
\hline langer dan 5 jaar geleden & & $-0,053$ & $-0,138$ & $-0,189$ \\
\hline Aantal keer werkloos of arbeidsongeschikt & & 0,028 & 0,035 & 0,024 \\
\hline Zelfregulatie & & & $-0,018$ & $-0,018$ \\
\hline Intrinsieke motivatie & & & $0,161^{* *}$ & 0,016 \\
\hline Risicoattitude & & & $0,194^{* * *}$ & $0,157^{* * *}$ \\
\hline \multicolumn{5}{|l|}{ Controle variabelen ${ }^{11}$} \\
\hline Vrouw & $-0,225^{*}$ & $-0,217^{*}$ & $-0,204^{*}$ & $-0,139$ \\
\hline \multicolumn{5}{|l|}{ Leeftijd (ref: 35-44 jaar) } \\
\hline 16-24 jaar & 0,039 & 0,030 & $-0,008$ & 0,312 \\
\hline 25-34 jaar & $-0,102$ & $-0,089$ & $-0,097$ & 0,033 \\
\hline 45-54 jaar & $-0,474^{* * *}$ & $-0,430^{* * *}$ & $-0,434^{* * *}$ & $-0,367^{* *}$ \\
\hline 55-64 jaar & $-1,318^{* * *}$ & $-1,230^{* * *}$ & $-1,291^{* * *}$ & $-0,935^{* * *}$ \\
\hline \multicolumn{5}{|l|}{ Opleiding (ref: mbo) } \\
\hline bo/vmbo & $-0,117$ & $-0,139$ & $-0,086$ & $-0,020$ \\
\hline havo/vwo & 0,102 & 0,092 & 0,117 & 0,129 \\
\hline hbo & 0,003 & $-0,055$ & $-0,070$ & $-0,104$ \\
\hline wo & $0,443^{* *}$ & $0,401^{* *}$ & $0,386^{* *}$ & $0,316^{*}$ \\
\hline Over 5 jaar bij ander bedrijf willen werken & & & & $0,703^{* * *}$ \\
\hline Constante term & $0,994^{* * *}$ & $1,013^{* * *}$ & $0,948^{* * *}$ & $3,711^{* * *}$ \\
\hline Pseudo-R-kwadraat & 0,090 & 0,104 & 0,117 & 0,250 \\
\hline $\mathrm{N}$ & 539 & 539 & 537 & 537 \\
\hline
\end{tabular}

${ }^{*} p<0.10{ }^{* *} p<0.05 * * * p<0.01$

1) Overige controles: sector van activiteit, burgerlijke staat, aantal kinderen en dummy voor schoolverlaters in de afgelopen 2 jaar. Daarnaast bevat het model 4 coëfficiënten voor de drempelwaardes van de latente afhankelijke variabele. 


\section{Conclusie}

In dit rapport hebben wij het formele en informele leren en de kennisontwikkeling in Nederland in beeld gebracht aan de hand van drie peilingen van de ROA Levenslang Leren Enquête (2004, 2007 en 20IO). Zowel het formele als het informele leren blijken sterk verankerd te zijn in het werk. Ruim de helft van de werkenden heeft in de afgelopen twee jaar een voor het werk relevante cursus of training gevolgd. Daarnaast wordt $28 \%$ procent van de werktijd besteed aan taken waarvan men kan leren. Hoewel de trainingsparticipatie tussen 2004 en 2010 nagenoeg onveranderd is gebleven, is het percentage van de werktijd dat werkenden besteden aan taken waarvan men kan leren in diezelfde periode licht gedaald. Het informele leren speelt echter nog steeds een cruciale rol bij het leren van werkenden. Ongeveer 93\% van de tijd die werkenden besteden aan leerzame activiteiten heeft betrekking op het informele leren op het werk. Analyses laten zien dat de kennisontwikkeling van werkenden samenhangt met zowel het formele als het informele leren. Daarom is het niet verwonderlijk dat de kennisontwikkeling van werkenden tussen 2004 en 2010 niet significant is veranderd.

Uit de in de vorige hoofdstukken gepresenteerde onderzoeksresultaten kunnen op een aantal beleidsterreinen conclusies worden getrokken:

- Het versterken van het menselijk kapitaal van werkenden.

- Het vergroten van de inzetbaarheid van de niet-werkenden.

- Het op peil houden van het menselijk kapitaal van de 45 -plussers.

\section{Het versterken van het menselijk kapitaal van werkenden}

In 2010 blijkt het verschil in scholingsparticipatie tussen vrouwen en mannen te zijn verdwenen. Specifiek beleid op dit terrein blijkt dus niet meer nodig te zijn. Verschillende persoonlijkheidskenmerken spelen echter wel een belangrijke rol bij het ontplooien van leeractiviteiten. Mensen met een grotere intrinsieke motivatie om te leren blijken zowel meer cursussen en trainingen te volgen als ook meer informeel te leren op hun werk. Maar ook andere persoonlijkheidskenmerken, zoals openheid voor ervaring en meegaandheid hangen positief samen met cursusdeelname of de bereidheid om aan scholing deel te nemen. Ook blijkt dat mensen die meer risico willen nemen meer tijd spenderen aan taken waarvan zij kunnen leren. De vraag in hoeverre iemands persoonlijkheid verandert gedurende de levensloop en veranderd kan worden door beleidsinterventies is onderwerp van debat. Er zijn echter signalen dat vroege interventies effecten kunnen hebben op iemands persoonlijkheid 
(Almlund e.a., 20II). Dit suggereert dat het stimuleren van bepaalde attitudes in het initieel onderwijs positieve effecten kunnen hebben op het levenslang leren later in de loopbaan.

Het leren van werkenden heeft echter voor het overgrote deel betrekking op activiteiten die niet los gezien kunnen worden van de dagelijkse werkzaamheden. Het is wat dit betreft pijnlijk dat het informele leren op het werk de afgelopen jaren is verminderd. Het is echter de vraag of de overheid het leven lang leren binnen bedrijven wel adequaat zou kunnen stimuleren. Het lijkt dan immers belangrijker om te kijken naar de leercultuur binnen bedrijven. Bedrijven kunnen de leercultuur binnen hun organisatie versterken door (I) expliciet rekening te houden met de kennis en vaardigheden die iemand door verandering van werkzaamheden kan opbouwen, en (2) het bevorderen van de samenwerking tussen ervaren en minder ervaren medewerkers. De overheid zal de leercultuur binnen bedrijven niet direct kunnen beïnvloeden. Het onderzoek laat echter ook zien dat cursusparticipatie en het informele leren op het werk sterk samenhangen. Dit betekent dat het stimuleren van de deelname aan cursussen en trainingen ook het informele leren van werkenden zou kunnen bevorderen. Langs deze weg zou de negatieve trend in het informele leren kunnen worden gekeerd.

Een mogelijkheid om de cursusparticipatie te stimuleren is het financieel faciliteren daarvan, bijvoorbeeld door middel van een voucher of ontwikkelingscheque (zie ook Van Breugel e.a., 20II). Dergelijke vouchers kunnen door de overheid zelf worden aangeboden of via de werkgevers. Uit onze analyses blijkt dat werkenden eerder bereid zijn om een scholingsvoucher te besteden wanneer deze door de werkgever zelf worden aangeboden. Een door de werkgever aangeboden voucher stimuleert echter vooral het gebruik daarvan bij mensen die meegaand zijn. Bij hen speelt een leermotief dus een minder belangrijke rol. Een door de overheid aangeboden voucher stimuleert daarentegen vooral mensen die open staan voor nieuwe ervaringen (en dus een leermotief hebben) om aan scholing deel te gaan nemen.

Er is een harde kern van een op de vijf werknemers, die gedurende hun loopbaan nog nooit een training of cursus heeft gevolgd. Het gaat hier vooral om laagopgeleiden en werkenden in de sectoren horeca, handel en cultuur. Het is niet duidelijk of hier sprake is van marktfalen. Het is immers mogelijk dat het voor degenen die in deze functies werkzaam zijn voor een goede uitoefening van hun werk niet noodzakelijk is om hun competenties door bijscholing op peil te houden. Echter, vanuit het lange-termijn perspectief van een duurzame inzetbaarheid zijn dit wel duidelijke risicogroepen. Deze mensen zullen immers niet of nauwelijks in staat zijn om ander werk te kunnen krijgen als ze zich op een gegeven moment in hun loopbaan, bijvoorbeeld vanwege bepaalde belastende arbeidsomstandigheden, niet meer in hun huidige functie kunnen handhaven

Onze onderzoeksresultaten laten ook zien dat werkenden beter geëquipeerd zijn voor hun huidige baan dan voor een andere baan waarin zij zouden kunnen gaan werken. 
Dit laat zien dat de inzetbaarheid van werkenden bij verlies aan werk kwetsbaar is. Het kunnen krijgen van een nieuwe baan maakt het in ieder geval voor veel werkenden noodzakelijk om nieuwe kennis en vaardigheden te leren. Het zou wenselijk zijn als een eventuele scholingsvoucher zich vooral op deze scholingsbehoefte richt.

\section{Het vergroten van de inzetbaarheid van de niet-werkenden}

De scholingsbereidheid van werklozen is niet significant verschillend van die van werkenden. Werklozen volgen echter vaker scholing dan de inactieven die zich niet aanbieden op de arbeidsmarkt. Hieruit blijkt dat voor werklozen de afstand tot de arbeidsmarkt duidelijk kleiner is dan voor de inactieve beroepsbevolking. Ook de bereidheid om een scholingsvoucher te gaan gebruiken is bij werklozen significant groter dan bij de werkenden en de inactieve beroepsbevolking, zelfs na controle voor persoonlijkheidskenmerken. Omdat bekostiging van scholing doorgaans een probleem is en het rendement van scholing onzeker is kan worden geconcludeerd dat een arbeidsmarktgericht scholingsbeleid gericht op de werkloze beroepsbevolking een effectief middel kan zijn om de extensieve marge van het arbeidsaanbod te vergroten. Daarentegen zal het aanbieden van een scholingsvoucher aan de inactieve beroepsbevolking op dit punt weinig soelaas bieden.

Onder niet-werkenden die een voucher van de overheid kunnen inzetten voor het volgen van scholing zijn vooral degenen met een sterke risicoattitude bereid de voucher te gebruiken. Dit illustreert dat het investeren in scholing voor niet-werkenden een risicovolle investering is, omdat het rendement, bij gebrek aan een baan, onzeker is. Vanuit dit oogpunt zou het zeer wenselijk zijn als werklozen die een scholing wordt aangeboden bij het behalen van een certificaat een werkgarantie krijgen. Daarentegen lijkt het weinig effectief om scholingsvouchers te verstrekken aan werkzoekenden die onzeker zijn of ze door het gebruik van de voucher wel werk kunnen vinden.

\section{Het op peil houden van het menselijk kapitaal van oudere arbeidskrachten}

Vanwege de wenselijkheid om de leeftijd waarop werkenden met pensioen gaan naar achteren te schuiven, wordt het leren door oudere arbeidskrachten beleidsmatig met zorg gevolgd. Onze gegevens laten op dit punt echter gunstige ontwikkelingen zien: de scholingsparticipatie van oudere werknemers is tussen 2004 en 2010 toegenomen. Dit ondersteunt de uitkomsten van Montizaan e.a. (20I0) die laten zien dat mensen die een financiële prikkel krijgen om later met pensioen te gaan meer scholing gaan volgen. Uit het onderzoek van Montizaan e.a. blijkt echter wel dat dit alleen betrekking heeft op werkenden die werkzaam zijn in grote organisaties.

Iemands kennis wordt in belangrijke mate door ervaring opgebouwd. Dit kan een reden zijn waarom ouderen minder aan cursussen deelnemen. Ook blijkt trainingsparticipatie sterk te stijgen als mensen met een substantiële verandering van de inhoud van hun werk worden geconfronteerd. Onze onderzoeksresultaten laten ook zien dat 
de kennisontwikkeling van oudere werknemers tussen 2004 en 2010 zich positief ontwikkelt. Veranderingen van werkzaamheden stimuleren de kennisontwikkeling omdat men dan nieuwe vaardigheden moet leren. Onze analyses laten zien dat dit ook werkt op oudere leeftijd. Daarnaast is het opmerkelijk dat de lagere bereidheid onder 55-plussers om een scholingsvoucher te gaan besteden zich vooral voordoet als ze de voucher van de overheid krijgen. Dit suggereert dat door de overheid gefaciliteerde scholing door middel van een voucher minder effectief is voor het stimuleren van de trainingsparticipatie onder 55-plussers dan wanneer de voucher via de werkgever wordt aangeboden.

Uit ons onderzoek blijkt dat oudere werkenden niet vaker denken dat ze de komende 5 jaar hun baan zullen kwijtraken dan jongeren. Daarentegen denken 45-plussers wel vaker dat ze een kleinere kans hebben om een andere baan op een vergelijkbaar niveau te kunnen krijgen als ze daarnaar op zoek gaan. Dit illustreert dat ouderen veel beter zijn toegerust voor hun huidige baan dan voor een mogelijk alternatieve functie. Het laat ook zien dat de duurzame inzetbaarheid van oudere werkenden vooral wordt aangetast wanneer ze hun huidige baan kwijtraken. Omdat oudere werkenden nog maar relatief kort op de arbeidsmarkt actief blijven, is het vaak minder aantrekkelijk om in de vereiste bij- of scholing te investeren. Dit maakt het belangrijk om vroegtijdig te investeren in de inzetbaarheid van werkenden. Daarom is het, zoals hierboven al werd aangegeven, belangrijk dat mensen, reeds eerder in hun loopbaan door functieroulatie en/of verandering van het takenpakket binnen hun functie bredere kennis en vaardigheden opbouwen. 


\section{Literatuur}

Almlund M., Duckworth A., Heckman J., Kautz T. (20II). Personality psychology and economics. IZA DP 550 , Bonn.

Borghans L., Golsteyn B., De Grip A. (2006), Meer werken is meer leren. Determinanten van kennisontwikkeling. 's-Hertogenbosch: CINOP.

Borghans L., Golsteyn B., De Grip A. (2007), Werkend leren, Economische Statistische Berichten, jaargang 92: 260-263.

Borghans L., Golsteyn B., De Grip A. (2008a). Betekenis (in)formeel leren voor kennisontwikkeling van de beroepsbevolking, In: C. Doets, W. van Esch, A. Westerhuis (eds), Een brede verkenning van een leven lang leren, CINOP, 's-Hertogenbosch (I57-I72).

Borghans L., Duckworth A., Heckman J., Ter Weel B. (2008b). The economics and psychology of personality traits. Journal of Human Resources, 43(4), 972-1059.

Borghans L., Golsteyn B., de Grip A., Nelen A. (2009). De betekenis van het leren op het werk. Utrecht: ecbo

Breugel, G. van, de Grip A., Dohmen D. (2011). Ontwikkelingscheque: uitwerking advies Denktank Leren en Werken. ROA-R-2011/3, Maastricht.

Carey K., Neal D., Collins S. (2004). A psychometric analysis of the self regulation questionnaire. Addictive Behaviors 29(2), 253-260

Dohmen T., Falk A., Huffman D., Sunde U., Schupp J., Wagner, G. (20II). Individual risk attitudes: measurement, determinants and behavioral consequences. Journal of the European Economic Association, 9(3): 522-550.

Fouarge D., de Grip A. (20II). Depreciatie van menselijk kapitaal. Maastricht: ROA rapport (ROA-R-2OII/I).

Fouarge D., Schils T., de Grip A. (2010). Why Do Low-Educated Workers Invest Less in Further Training? IZA DP No 5I80, Bonn. 
Goldberg L. (1992). The development of markers for the Big-Five factor structure. Psychological Assessment, 4(I), 26-42.

Goldberg L. (1999). International Personality Item Pool: A scientific collaboratory for the development of advanced measures of personality and other individual differences, http://ipip.ori.org/ipip/.

Montizaan R., Cörvers F., de Grip A. (20IO). The effects of pension rights and retirement age on training participation: Evidence from a natural experiment. Labour Economics, I7(I), 240-247.

Strathman A., Gleicher F., Boninger D., Edwards C. (1994). The consideration of future consequences: Weighing immediate and distant outcomes of behavior. Journal of Personality and Social Psychology, 66(4), 742-752.

Tharenou P. (200I). The relationship of training motivation to participation in training and development. Journal of Occupational and Organizational Psychology, 74(5), 599-62I. 


\section{Bijlage A: ROA Levenslang Leren Enquête}

\section{Samenstelling}

De ROA Levenslang Leren Enquête werd gehouden onder de leden van het CentERpanel in de maanden oktober/november van 2004, 2007 en 20I0. In totaal gaat het om 2.376 respondenten in 2004 (waarvan I.968 jonger dan 65 jaar), I.776 respondenten in 2007 (waarvan 1.404 jonger dan 65 jaar) en I.974 respondenten in 2010 (waarvan I.459 jonger dan 65 jaar). De samenstelling naar geslacht, leeftijd, opleidingsniveau en arbeidsmarkt status is weergegeven in tabel A.I. Voor de beschrijvende analyses in dit rapport is de data gewogen naar geslacht, leeftijd en opleidingsniveau.

Tabel A.1

Samenstelling van de steekproef

\begin{tabular}{|c|c|c|c|}
\hline & 2004 & 2007 & 2010 \\
\hline Totaal & 2.376 & 1.776 & 1.974 \\
\hline \multicolumn{4}{|l|}{ Geslacht } \\
\hline $\operatorname{man}$ & 1.244 & 938 & 1.055 \\
\hline vrouw & 1.132 & 838 & 919 \\
\hline \multicolumn{4}{|l|}{ Leeftijd } \\
\hline 16-24 jaar & 159 & 90 & 82 \\
\hline 25-34 jaar & 402 & 249 & 155 \\
\hline 35-44 jaar & 473 & 305 & 334 \\
\hline 45-54 jaar & 528 & 385 & 373 \\
\hline 55-64 jaar & 406 & 375 & 515 \\
\hline $65+$ jaar & 408 & 372 & 515 \\
\hline \multicolumn{4}{|l|}{ Opleidingsniveau } \\
\hline basisonderwijs & 139 & 94 & 104 \\
\hline vmbo & 633 & 492 & 534 \\
\hline havo/vwo & 311 & 229 & 230 \\
\hline mbo & 463 & 345 & 330 \\
\hline hbo & 564 & 415 & 518 \\
\hline wo & 263 & 197 & 254 \\
\hline \multicolumn{4}{|l|}{ Arbeidsmarktstatus } \\
\hline werknemer in loondienst & 1.197 & 872 & 900 \\
\hline zelfstandige of meewerkend gezinslid & 93 & 69 & 111 \\
\hline
\end{tabular}


Tabel A.1

Samenstelling van de steekproef

\begin{tabular}{|c|c|c|c|}
\hline & 2004 & 2007 & 2001 \\
\hline werkzoekend & 52 & 28 & 40 \\
\hline arbeidsongeschikt & 107 & 79 & 86 \\
\hline huisvrouw/huisman & 312 & 225 & 198 \\
\hline student of scholier & 141 & 76 & 64 \\
\hline (vroeg)gepensioneerd & 406 & 381 & 521 \\
\hline $\begin{array}{l}\text { vrijwilligers of iets } \\
\text { In het rapport wordt }\end{array}$ & $\begin{array}{r}68 \\
\text { (basiso }\end{array}$ & $\begin{array}{r}46 \\
\text { bo), } \mathrm{mi}\end{array}$ & $\begin{array}{r}54 \\
\text { leiden }\end{array}$ \\
\hline
\end{tabular}

\section{Kernvariabelen}

De data is uniek in de zin dat het o.a. gedetailleerd ingaat op cursusparticipatie, informeel leren en kennisontwikkeling op een wijze dat het mogelijk maakt om de bevindingen in de loop der jaren te vergelijken. Van een aantal kernvariabelen wordt in tabel A.2 aangeven hoe deze gemeten zijn.

\section{Tabel A.2}

Meting van een aantal kernvariabelen in de ROA Levenslang Leren Enquête

\begin{tabular}{|ll}
\hline Variabele & Vraag \\
\hline Deelname aan cursussen en trainingen & $\begin{array}{l}\text { Hoeveel cursussen en/of trainingen hebt u de afgelopen twee jaar afgerond? } \\
\text { Laat pure hobby-cursussen (bridge, schilderen) buiten beschouwing. Cursussen die u als } \\
\text { hobby ziet, maar voor anderen nuttig kunnen zijn voor het werk tellen wel mee. }\end{array}$ \\
\hline Informeel leren & Hoeveel procent van de werktijd besteedt u aan taken waarvan u kunt leren? \\
\hline Kennisontwikkeling & $\begin{array}{l}\text { Stelt u zich voor welke kennis en vaardigheden nodig zijn voor uw werk om in uw ogen } \\
\text { optimaal te kunnen functioneren. Als dit ideaal gelijk is aan 100, hoe hoog schat u dan } \\
\text { uw vaardigheden in: } \\
\text { - twee jaar geleden } \\
\text { - op dit moment? } \\
\text { De kennisontwikkeling wordt gemeten als het verschil tussen de twee antwoorden. }\end{array}$
\end{tabular}

\section{Persoonlijkheid}

De Big Five is een standaard in de psychologische literatuur (Goldberg, I992). Het kenmerkt iemands persoonlijkheid langs de volgende vijf dimensies: Openheid voor ervaringen (Openness to Experience), Zorgvuldigheid (Conscientiousness), Extraversie (Extraversion), Meegaandheid (Agreeableness) en Neuroticisme (Neuroticism). Deze persoonlijkheidskenmerken zijn gemeten in de 2005 en 2009 peilingen van het $D N B$ Household Survey en gekoppeld aan de 2004 en 2010 peilingen van de ROA Levenslang Leren Enquête. ${ }^{32}$

32. Elke dimensie is door middel van tien vragen gemeten (Goldberg, 1999). Voor respondenten die niet gekoppeld konden worden aan de DNB Household Survey imputeren wij het gemiddeld score op elk van de dimensies, en wij controleren voor imputatie in onze modellen. 
Intrinsiek motivatie om te leren en zelfregulatie zijn in de 20 Io peiling van de $R O A$ Levenslang Leren Enquête gemeten. Het gaat om specifiekere persoonlijkheidskenmerken dan de Big Five. Intrinsieke motivatie om te leren is gemeten aan de hand van vijf geselecteerde items uit de schaal van Theranou (200I) waarop respondenten op een schaal van I tot 5 konden aangeven in welke mate de uitspraak op hen van toepassing is. Voorbeelden zijn: "Ik zou graag mijn vaardigheden willen verbeteren", en "Ik ben bereid om me in te spannen op een cursus om mijn kennis en vaardigheden te verbeteren".

Zelfregulatie verwijst naar het vermogen van individuen om hun eigen gedrag te bepalen. Het wordt gemeten aan de hand van I4 uitspraken die zijn ontleend aan Carey e.a. (2004) waarvoor respondenten op een schaal van I tot 5 konden aangeven in welke mate deze op hen van toepassing zijn. Voorbeelden van deze uitspraken zijn: "Ik raak gemakkelijk afgeleid van mijn doelen" en "Ik realiseer mij de gevolgen van mijn daden pas als het te laat is" (beide schalen uit deze twee voorbeelden zijn omgekeerd). De twee concepten (intrinsieke motivatie en zelfregulatie) zijn gecorreleerd, maar deze correlatie niet sterk (o,Io).

Daarnaast worden in de literatuur risicoattitude en tijdoriëntatie in verband gebracht met scholing.. Risicoattitude wordt gemeten aan de hand van de door Dohmen e.a. (20II) gevalideerde vraag: "Hoe ziet u uzelf? Bent $\mathrm{u}$ in het algemeen iemand die bereid is om risico's te nemen of probeert u risico's te vermijden?". Respondenten konden antwoorden op een schaal van o "helemaal niet bereid om risico's te nemen" tot Io "zeer bereid om risico's te nemen". Iemands tijdoriëntatie is gemeten in de 2009 peiling van de DNB Household Survey aan de hand van I2 uitspraken uit Strathman e.a. (1994). Voorbeelden zijn: "Ik denk na over hoe dingen in de toekomst kunnen zijn, en probeer deze in mijn leven van iedere dag te beïnvloeden" en "Vaak houd ik mij bezig met zaken die pas over enige jaren gevolgen zullen hebben”. Respondenten konden aangeven (op een schaal van I tot 7 ) in welke mate de uitspraken op hun van toepassing zijn.

Voor al deze indicatoren geldt dat wij gebruikmaken van gestandaardiseerde scores.

\section{Selectie van waarnemingen}

De analyses in alle hoofdstukken zijn gebaseerd op respondenten tussen de I6 en 64 jaar. De enige uitzondering hierop is paragraaf 3.4, dat gebaseerd is op 45-70 jarigen. Overige selecties van waarnemingen worden in de tekst vermeld. 



\section{Bijlage B: Aspecten van werk}

Tabel B.1

Lijst van aspecten van het werk waaruit respondenten konden kiezen
1. omgaan met mensen
2. mensen beïnvloeden of overtuigen
3. duidelijk communiceren
4. leiding geven
5. coaching
6. nauwkeurigheid
7. stressbestendigheid
8. doorzettingsvermogen
9. besluitvaardigheid
10. flexibiliteit
11. vakspecifieke kennis
12. administratieve vaardigheden
13. werken met computers
14. analytisch denken
15. cijfermatig inzicht
16. technische kennis
17. commercieel inzicht
18. informatie verzamelen en verwerken
19. algemene kennis
20. fysieke conditie en kracht
21. creativiteit
22. organiseren
23. time management
24. schrijven
25. presenteren
26. buitenlandse talen 



\section{Bijlage C: Aanvullende tabellen bij hoofdstuk 3}

Tabel C.1

Kenmerken van werklozen en inactieven die in de afgelopen twee jaar (probit coëfficiënten), 2004 en 2010

(1) (2)

Verklarende variabelen

Big Five

open voor nieuwe ervaringen

zorgvuldig

extravert

meegaand

neurotisch

Zelfregulatie

Intrinsieke motivatie

Risicoattitude

Tijdoriëntatie

Controle variabelen ${ }^{11}$

\begin{tabular}{|c|c|c|c|}
\hline Vrouw & $0,392^{* * *}$ & $0,448^{* * *}$ & $0,717^{* *}$ \\
\hline \multicolumn{4}{|l|}{ Leeftijd (ref: 35-44 jaar) } \\
\hline 16-24 jaar & $-0,140$ & $-0,212$ & - \\
\hline 25-34 jaar & $-0,296$ & $-0,347^{*}$ & $-0,209$ \\
\hline 45-54 jaar & 0,051 & 0,036 & 0,151 \\
\hline 55-64 jaar & $-0,203$ & $-0,262$ & 0,029 \\
\hline \multicolumn{4}{|l|}{ Opleiding (ref: mbo) } \\
\hline bo/vmbo & $-0,448^{* * *}$ & $-0,420^{* * *}$ & $-0,109$ \\
\hline havo/vwo & $-0,074$ & $-0,109$ & $-0,281$ \\
\hline hbo & 0,229 & 0,162 & 0,265 \\
\hline wo & 0,195 & 0,135 & $0,832^{* *}$ \\
\hline Werkloos (ref: inactief) & $0,512^{* * *}$ & $0,487^{* * *}$ & $0,830^{* * *}$ \\
\hline Constante term & $-0,974$ & $-0,946^{* * *}$ & $-2,051^{* * *}$ \\
\hline Pseudo-R-kwadraat & 0,03 & 0,075 & 0,191 \\
\hline$N$ & 760 & 760 & 280 \\
\hline
\end{tabular}

${ }^{*} \mathrm{p}<0.10$ ** $\mathrm{p}<0.05^{* * *} \mathrm{p}<0.01$

- geen waarneming

1) Overige controles: burgerlijke staat, aantal kinderen, jaardummy voor 2004 (in model 1 en 2)
(3)

$0,136^{* *}$
$-0,101^{*}$
$-0,015$
$-0,005$
$-0,062$

0,044

$0,357^{* * *}$

0,086

$-0,034$ 


\section{Tabel C.2}

Kenmerken van werklozen en inactieven nog nooit een training hebben gevolgd (probit coëfficiënten), (referentie: ooit training gevolgd), 2004 en 2010

\section{(1)}

\section{Verklarende variabelen}

\section{Big Five}

open voor nieuwe ervaringen

zorgvuldig

extravert

meegaand

neurotisch

Zelfregulatie

Intrinsieke motivatie

Risicoattitude

Tijdoriëntatie

Controle variabelen ${ }^{1}$

Vrouw

Leeftijd (ref: 35-44 jaar)

16-24 jaar

25-34 jaar

45-54 jaar

55-64 jaar

Opleiding (ref: mbo)

bo/vmbo

havo/vwo

hbo

wo

Werkloos (ref: inactief)

Constante term

Pseudo-R-kwadraat

N

${ }^{*} p<0.10 * * p<0.05$ *** $p<0.01$

- geen waarneming

1) Overige controles: burgerlijke staat, aantal kinderen, jaardummy voor 2004 (in model 1 en 2 )
(3)

$-0,074$

$-0,058$

$-0,046$

$-0,050$

$-0,043$

\section{$-0,106$}

$-0,332^{* * *}$

$-0,098$

$-0,062$

$-0,109$

$-0,148$

$-0,116$

$1,193^{* *}$

$0,706^{* * *}$

$1,528^{* * *}$

$0,729^{*}$

$-0,005$

$-0,091$

0,071

0,040

$\begin{array}{lll}0,503^{* *} & 0,491^{* * *} & 0,332 \\ -0,021 & -0,010 & -0,415 \\ -0,317^{*} & -0,290 & -0,498 \\ -0,428 & -0,429 & -0,425 \\ -0,589^{* * *} & -0,603^{* * *} & -0,894^{* *} \\ -0,587^{* *} & -0,596^{* * *} & -0,339 \\ 0,089 & 0,095 & 0,199 \\ 699 & 699 & 260\end{array}$

0,081

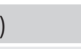


Tabel C.3

Kenmerken van werknemers en werklozen en inactieven die scholingsvoucher van hun werkgever of van de overheid gaan besteden (ordered probit model), naar randomgroep, 2010

\begin{tabular}{|c|c|c|c|c|c|c|}
\hline & \multicolumn{2}{|c|}{$\begin{array}{l}\text { Werknemer } \\
\text { voucher van werkgever }\end{array}$} & \multicolumn{2}{|c|}{$\begin{array}{l}\text { Werknemer } \\
\text { voucher van overheid }\end{array}$} & \multicolumn{2}{|c|}{$\begin{array}{l}\text { Werkloos of inactief } \\
\text { voucher van overheid }\end{array}$} \\
\hline \multicolumn{7}{|l|}{ Verklarende variabelen } \\
\hline \multicolumn{7}{|l|}{ Big Five } \\
\hline open voor nieuwe ervaringen & 0,012 & & $0,117^{*}$ & & $0,216^{* *}$ & \\
\hline zorgvuldig & $-0,130^{* *}$ & & 0,020 & & $-0,035$ & \\
\hline extravert & 0,024 & & 0,020 & & $-0,081$ & \\
\hline meegaand & $0,227^{* * *}$ & & 0,086 & & 0,058 & \\
\hline neurotisch & 0,085 & & $-0,063$ & & 0,037 & \\
\hline Zelfregulatie & & $-0,017$ & & 0,84 & & $-0,026$ \\
\hline Intrinsieke motivatie & & $0,682^{* * *}$ & & $0,662^{* * *}$ & & $0,610^{* * *}$ \\
\hline Risicoattitude & & 0,035 & & 0,034 & & $0,274^{* * *}$ \\
\hline Tijdoriëntatie & & 0,027 & & $-0,053$ & & 0,040 \\
\hline \multicolumn{7}{|l|}{ Controle variabelen ${ }^{1)}$} \\
\hline Vrouw & 0,147 & $0,221^{*}$ & 0,040 & $-0,002$ & $0,377^{* *}$ & $0,314^{*}$ \\
\hline \multicolumn{7}{|l|}{ Leeftijd (ref: $35-44$ jaar) } \\
\hline 16-24 jaar & $-0,327$ & $-0,273$ & $-0,725^{*}$ & $-0,758^{*}$ & $-0,493$ & $-0,960$ \\
\hline 25-34 jaar & 0,160 & 0,072 & 0,242 & 0,042 & $-0,161$ & $-0,237$ \\
\hline 45-54 jaar & $-0,151$ & $-0,064$ & $-0,216$ & $-0,238$ & 0,027 & $-0,208$ \\
\hline 55-64 jaar & $-0,327^{* *}$ & $-0,213$ & $-0,694^{* * *}$ & $-0,662^{* * *}$ & $-0,148$ & $-0,356$ \\
\hline \multicolumn{7}{|l|}{ Opleiding (ref: mbo) } \\
\hline bo/vmbo & $-0,408^{* *}$ & $-0,262$ & $-0,156$ & 0,098 & $-0,7006^{* * *}$ & $-0,696^{* * *}$ \\
\hline havo/vwo & $-0,218$ & $-0,051$ & 0,119 & 0,278 & $-0,290$ & $-0,208$ \\
\hline hbo & $0,085^{*}$ & 0,022 & 0,139 & 0,227 & $-0,119$ & $-0,070$ \\
\hline wo & $0,493^{* * *}$ & 0,314 & $-0,030$ & 0,206 & 0,034 & 0,149 \\
\hline Werkloos (ref: inactief) & & & & & $0,787^{* * *}$ & $0,555^{* *}$ \\
\hline Pseudo-R-kwadraat & 0,058 & 0,106 & 0,050 & 0,098 & 0,083 & 0,182 \\
\hline$N$ & 410 & 383 & 439 & 403 & 296 & 285 \\
\hline
\end{tabular}

* $p<0.10 * * p<0.05 * * * p<0.01$

1) Overige controles: burgerlijke staat en aantal kinderen. Daarnaast bevat het model 4 coëfficiënten voor de drempelwaardes van de latente afhankelijke variabele 


\section{Tabel C.4}

Kenmerken van werknemers die de scholingsvoucher eerder zullen besteden als ze de cursus kunnen volgen in de baas $z^{\prime} n$ tijd in plaats van in hun eigen tijd (probit model), 2010')

\begin{tabular}{|c|c|c|c|}
\hline & (1) & (2) & (3) \\
\hline \multicolumn{4}{|l|}{ Verklarende variabelen } \\
\hline \multicolumn{4}{|l|}{ Big Five } \\
\hline open voor nieuwe ervaringen & & $0,143^{* *}$ & \\
\hline zorgvuldig & & $-0,102^{*}$ & \\
\hline extravert & & $-0,052$ & \\
\hline meegaand & & 0,080 & \\
\hline neurotisch & & 0,094 & \\
\hline Zelfregulatie & & & 0,017 \\
\hline Intrinsieke motivatie & & & $0,434^{* * *}$ \\
\hline Risicoattitude & & & $-0,163^{* * *}$ \\
\hline Tijdoriëntatie & & & $0,172^{* * *}$ \\
\hline \multicolumn{4}{|l|}{ Controle variabelen ${ }^{2)}$} \\
\hline Vrouw & 0,053 & 0,050 & 0,123 \\
\hline \multicolumn{4}{|l|}{ Leeftijd (ref: 35-44 jaar) } \\
\hline 16-24 jaar & $-0,953^{* *}$ & $-0,978^{* *}$ & $-0,965^{* *}$ \\
\hline 25-34 jaar & 0,186 & 0,187 & 0,030 \\
\hline 45-54 jaar & $-0,259^{*}$ & $-0,236^{*}$ & $-0,201$ \\
\hline 55-64 jaar & $-0,118$ & $-0,111$ & $-0,113$ \\
\hline \multicolumn{4}{|l|}{ Opleiding (ref: mbo) } \\
\hline bo/vmbo & $-0,159$ & $-0,155$ & $-0,114$ \\
\hline havo/vwo & 0,124 & 0,101 & 0,206 \\
\hline hbo & 0,252 & 0,199 & $0,282^{*}$ \\
\hline wo & $0,399^{* *}$ & 0,313 & $0,376^{*}$ \\
\hline \multicolumn{4}{|c|}{ Random groepen (ref: werknemer/voucher van werkgever) } \\
\hline werknemer/voucher van overheid & $-0,016$ & $-0,020$ & $-0,036$ \\
\hline Constante term & 0,114 & 0,166 & 0,171 \\
\hline Pseudo-R-kwadraat & 0,047 & 0,064 & 0,106 \\
\hline N & 600 & 600 & 561 \\
\hline \multicolumn{4}{|c|}{$\begin{array}{l}{ }^{*} p<0.10^{* *} p<0.05^{* * *} p<0.01 \\
\text { 1) De analyse beperkt zich tot werknemers omdat alleen zij scholing in de baas z'n tijd kunnen volgen. Omdat } \\
\text { sprake kan zijn van plafond effecten wordt in het model gecontroleerd voor de waarschijnlijkheid van gebruik } \\
\text { van de voucher voor een cursus in eigen tijd. }\end{array}$} \\
\hline
\end{tabular}


Tabel C.5

Kenmerken van mensen met een kleinere kans om cursus te volgen wanneer er een eigen bijdrage van $€ 250$ gevraagd wordt (probit model), 2010')

(1)

\section{Verklarende variabelen}

Big Five

open voor nieuwe ervaringen

zorgvuldig

extravert

meegaand

neurotisch

Zelfregulatie

Intrinsieke motivatie

Risicoattitude

Tijdoriëntatie

Controle variabelen ${ }^{2)}$

\begin{tabular}{|c|c|c|c|}
\hline Vrouw & $0,180^{*}$ & 0,140 & $0,217^{* *}$ \\
\hline \multicolumn{4}{|l|}{ Leeftijd (ref: 35-44 jaar) } \\
\hline 16-24 jaar & $-0,081$ & $-0,080$ & $-0,216$ \\
\hline 25-34 jaar & 0,221 & 0,193 & 0,143 \\
\hline 45-54 jaar & $-0,069$ & $-0,077$ & $-0,085$ \\
\hline 55-64 jaar & $-0,089$ & $-0,104$ & $-0,075$ \\
\hline \multicolumn{4}{|l|}{ Opleiding (ref: mbo) } \\
\hline bo/vmbo & $-0,127$ & $-0,127$ & $-0,179$ \\
\hline havo/vwo & $-0,238$ & $-0,229$ & $-0,222$ \\
\hline hbo & 0,037 & 0,036 & 0,085 \\
\hline wo & 0,097 & 0,076 & 0,171 \\
\hline \multicolumn{4}{|c|}{ Random groepen (ref: werknemer/voucher van werkgever) } \\
\hline werknemer/voucher van overheid & $-0,090$ & $-0,085$ & $-0,099$ \\
\hline werkloos/voucher van overheid & $-0,245$ & $-0,268$ & $-0,272$ \\
\hline inactief/voucher van overheid & 0,021 & $-0,002$ & $-0,047$ \\
\hline Constante term & $0,780^{* * *}$ & $0,841^{* * *}$ & $1,100^{* * *}$ \\
\hline Pseudo-R-kwadraat & 0,073 & 00,081 & 0,099 \\
\hline$N$ & 974 & 974 & 909 \\
\hline
\end{tabular}

${ }^{*} \mathrm{p}<0.10$ ** $\mathrm{p}<0.05$ *** $\mathrm{p}<0.01$

1) Omdat sprake zou kunnen zijn van bodem effecten (wie een lage waarschijnlijkheid kan niet een nog lagere waarschijnlijkheid rapporteren) wordt in de analyse gecontroleerd met de waarschijnlijkheid van gebruik van de voucher.

2) Overige controles: burgerlijke staat, aantal kinderen, bereidheid om scholingsvoucher te gebruiken.

$-0,099 * *$

$-0,347^{* * *}$

$-0,060$

$-0,025$

$-0,028$

$-0,092$

0,079

3)

.


Tabel C.6

Gekozen cursus in voucher vraag

\begin{tabular}{|c|c|c|c|}
\hline & \multicolumn{2}{|c|}{ Werknemer } & \multirow{2}{*}{$\begin{array}{c}\text { Werklozen en inactieven } \\
\text { voucher van overheid }\end{array}$} \\
\hline & voucher van werkgever & voucher van overheid & \\
\hline cursus omgaan met mensen & 4 & 5 & 5 \\
\hline cursus beïnvloeden of overtuigen & 5 & 3 & 0 \\
\hline cursus duidelijk communiceren & 5 & 3 & 2 \\
\hline cursus effectief leiderschap & 7 & 7 & 3 \\
\hline cursus effectief coachen & 7 & 6 & 1 \\
\hline cursus nauwkeurig werken & 0 & 1 & 0 \\
\hline cursus omgaan met stress & 3 & 4 & 4 \\
\hline cursus doorzettingsvermogen & 0 & 0 & 4 \\
\hline cursus doeltreffend besluiten nemen & 3 & 1 & 1 \\
\hline cursus flexibel werken & 1 & 0 & 0 \\
\hline cursus om uw vakkennis te vergroten & 28 & 26 & 14 \\
\hline cursus administratieve vaardigheden & 4 & 3 & 6 \\
\hline cursus omgaan met computers & 4 & 6 & 13 \\
\hline cursus analytisch denken & 1 & 1 & 0 \\
\hline cursus werken met cijfers & 2 & 2 & 2 \\
\hline cursus techniek & 6 & 4 & 6 \\
\hline cursus commercieel denken & 3 & 2 & 0 \\
\hline cursus omgaan met informatie & 0 & 1 & 1 \\
\hline cursus algemene kennis & 2 & 2 & 2 \\
\hline conditie- en krachttraining & 1 & 3 & 2 \\
\hline workshop creatief denken & 1 & 1 & 5 \\
\hline cursus effectief organiseren & 2 & 2 & 1 \\
\hline cursus time management & 3 & 4 & 0 \\
\hline cursus effectief schrijven & 1 & 2 & 1 \\
\hline cursus presenteren & 2 & 2 & 1 \\
\hline talencursus & 6 & 10 & 27 \\
\hline Totaal & 100 & 100 & 100 \\
\hline
\end{tabular}


Tabel C.7

Kenmerken van mensen die kiezen voor een specifieke cursus, 2010

(1)

(2)

(3)

\section{Verklarende variabelen}

Big Five

\begin{tabular}{lc} 
open voor nieuwe ervaringen & $0,101^{* * *}$ \\
zorgvuldig & 0,044 \\
\hline extravert & $-0,016$ \\
meegaand & 0,021 \\
\hline neurotisch & 0,021
\end{tabular}

Zelfregulatie

$0,071^{* *}$

Intrinsieke motivatie

$0,220^{* * *}$

Risicoattitude

0,052

Tijdoriëntatie

0,025

\section{Controle variabelen ${ }^{11}$}

\begin{tabular}{|c|c|c|c|}
\hline Vrouw & $-0,048$ & $-0,057$ & $-0,058$ \\
\hline \multicolumn{4}{|l|}{ Leeftijd (ref: 35-44 jaar) } \\
\hline 16-24 jaar & $-0,272$ & $-0,206$ & $-0,399$ \\
\hline 25-34 jaar & $-0,024$ & $-0,040$ & $-0,071$ \\
\hline 45-54 jaar & $-0,035$ & $-0,019$ & $-0,053$ \\
\hline 55-64 jaar & $-0,095$ & $-0,103$ & $-0,151$ \\
\hline \multicolumn{4}{|l|}{ Opleiding (ref: mbo) } \\
\hline bo/vmbo & $-0,206^{* *}$ & $-0,194^{* *}$ & $-0,160$ \\
\hline havo/vwo & $-0,292^{* *}$ & $-0,302^{* *}$ & $-0,243^{*}$ \\
\hline hbo & 0,110 & 0,080 & 0,084 \\
\hline wo & $-0,064$ & $-0,132$ & $-0,124$ \\
\hline \multicolumn{4}{|c|}{ Random groepen (ref: werknemer/voucher van werkgever) } \\
\hline werknemer/voucher van overheid & $-0,046$ & $-0,059$ & $-0,049$ \\
\hline werkloos/voucher van overheid & $-0,171$ & $-0,156$ & $-0,118$ \\
\hline inactief/voucher van overheid & $-0,183^{*}$ & $-0,205^{* *}$ & $-0,124$ \\
\hline Pseudo-R-kwadraat & 0,023 & 0,027 & 0,036 \\
\hline$N$ & 1.145 & 1.145 & 1.071 \\
\hline
\end{tabular}

${ }^{*} p<0.10 *{ }^{*} p<0.05 * * * 0<0.01$

1) Overige controles: burgerlijke staat, aantal kinderen, bereidheid om scholingsvoucher te gebruiken. Daarnaast bevat het model 3 coëfficiënten voor de drempelwaardes van de latente afhankelijke variabele. 
